\title{
Depositional Controls, Distribution, and Effectiveness of World's Petroleum Source Rocks
}

\section{U.S. GEOLOGICAL SURVEY BULLETIN 1931}




\section{Depositional Controls, Distribution, and Effectiveness of World's Petroleum Source Rocks}

By G.F. ULMISHEK and H.D. KLEMME 


\title{
DEPARTMENT OF THE INTERIOR
}

\author{
MANUEL LUJAN, JR., Secretary
}

U.S. GEOLOGICAL SURVEY

Dallas L. Peck, Director

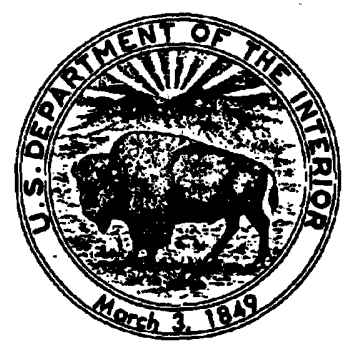

Any use of trade, product, or firm names in this publication is for descriptive purposes only and does not imply endorsement by the U.S. Government.

UNITED STATES GOVERNMENT PRINTING OFFICE: 1990

For sale by the

Books and Open-File Reports Section

U.S. Geological Survey

Federal Center

Box 25425

Denver, CO 80225

Library of Congress Cataloging-in-Publication Data

Ulmishek, Gregory F.

Depositional controls, distribution, and effectiveness of world's petroleum source rocks / by G.F. Ulmishek and H.D. Klemme.

p. $\quad \mathrm{cm} .-$ (U.S. Geological Survey bulletin ; 1931)

Includes bibliographical references.

Supt. of Docs. no.: I 19.3:1931

1. Petroleum-Geology. 2. Gas, Natural-Geology. 3. Geology,

Stratigraphic. I. Klemme, H. Douglas. II. Title. III. Series.

QE75.B9 no. 1931

[TN870.5]

$557.3 \mathrm{~s}-\mathrm{dc} 20$

[553.2'8]

$90-2900$ 


\section{CONTENTS}

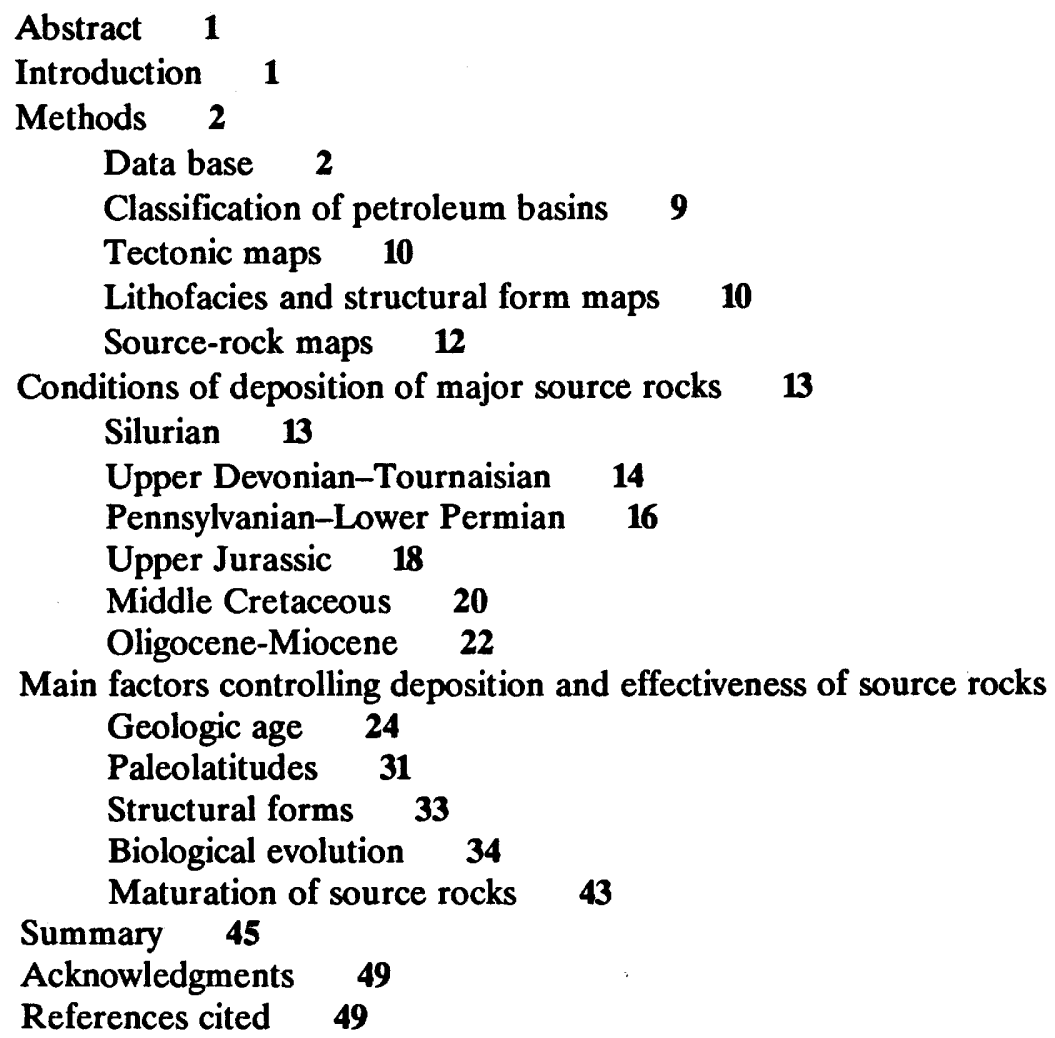

\section{PLATES}

[Plates are in pocket]

1-6. Maps showing plate tectonics, lithofacies, structural forms, petroleum basins, and source rocks:
1. Silurian interval
2. Upper Devonian-Tournaisian interval
3. Pennsylvanian-Lower Permian interval
4. Upper Jurassic interval
5. Middle Cretaceous interval
6. Oligocene-Miocene interval

\section{FIGURES}

1. Graph showing distribution of effective source rocks through geologic time 3

2. Chart showing basin classification scheme 11

3. Map showing distribution of evaporites and coals in the Pennsylvanian-Lower Permian stratigraphic interval 17 
4-16. Charts and graphs showing:

4. Relative areal extent of petroleum source rocks in the six principal stratigraphic intervals 25

5. Relative areas of deposited and destroyed source rocks in the six principal stratigraphic intervals 25

6. Relative areal extent of preserved source rocks versus effectiveness 26

7. Oil versus gas reserves generated by source rocks with kerogen types I and II and those with kerogen type III and coal 27

8. Original petroleum reserves generated versus those trapped in Upper Proterozoic through Quaternary strata 28

9. Vertical migration of petroleum 29

10. Relative areal distribution of source rocks of the six principal stratigraphic intervals by paleolatitudinal zones $\mathbf{3 2}$

11. Relative areal extent versus effectiveness of source rocks by paleolatitudinal zones 33

12. Effectiveness of source rocks deposited in various structural forms 34

13. Effectiveness of source rocks deposited in various structural forms within each of the six principal stratigraphic intervals 35

14. Changes in conditions of source-rock deposition through Phanerozoic time and related major events of biological evolution 36

15. Maturation times of effective source rocks 44

16. Cumulative source-rock deposition, source-rock maturation, and petroleum trapped 48

\section{TABLES}

1. Major productive basins containing source rocks of the six main petroleumgenerating intervals 4

2. Original petroleum reserves of major productive basins shown on the maps 9

\section{CONVERSION OF MEASUREMENTS}

Data in this report are given in customary inch-pound units because the metric system is not currently in use by the oil and gas industry of the United States.

\begin{tabular}{ll}
\hline \multicolumn{1}{c}{ Inch-pound unit } & \multicolumn{1}{c}{ Metric conversion } \\
\hline Foot $(\mathrm{ft})$ & $=0.3048$ meters \\
Mile $(\mathrm{mi})$ & $=1.609$ kilometers \\
Square mile $\left(\mathrm{mi}^{2}\right)$ & $=2.59$ square kilometers \\
Barrel of oil equivalent (BOE) & $=0.143$ metric tons of oil equivalent \\
\hline
\end{tabular}




\title{
Depositional Controls, Distribution, and Effectiveness of World's Petroleum Source Rocks
}

\author{
By G.F. Ulmishek ${ }^{1}$ and H.D. Klemme ${ }^{2}$
}

\section{Abstract}

Six stratigraphic intervals representing a third of Phanerozoic time contain petroleum source rocks that have provided more than 90 percent of the world's discovered original reserves of oil and gas. The six intervals are (1) Silurian (generated 9 percent of the world's reserves), (2) Upper Devonian-Tournaisian (8 percent of reserves), (3) Pennsylvanian-Lower Permian (8 percent of reserves), (4) Upper Jurassic (25 percent of reserves), (5) middle Cretaceous (29 percent of reserves), and (6) OligoceneMiocene (12.5 percent of reserves). This uneven distribution of source rocks in time displays no obvious cyclicity, and the factors that controlled the formation of source rocks varied from interval to interval.

Three maps have been prepared for each interval in this study: a plate tectonic map, a facies and structural form map, and a petroleum source-rock map. The locations and amounts of discovered petroleum reserves generated by each interval's source rocks are shown on the latter two of these maps. Analysis of the maps indicates that several primary factors controlled the areal distribution of source rocks, their quality, and their effectiveness (amounts of discovered original oil and gas reserves generated by these rocks). These factors are geologic age, paleolatitude of the depositional areas, structural (morphotectonic) forms in which the source rocks were deposited, and the evolution of biota. The ages of maturation periods for these source rocks demonstrate that the majority of discovered oil and gas is very young; more than $\mathbf{8 0}$ percent of the world's oil and gas original reserves have been generated since Aptian time, and nearly half of the world's petroleum ${ }^{3}$ has been generated and trapped since the Oligocene.

Manuscript approved for publication January 25, 1990.

${ }^{1}$ U.S. Geological Survey, Box 25046, MS 940, Denver Federal Center, Denver, CO 80225.

${ }^{2}$ GeoBasins Limited, RR1, Box 279B, Bondville, VT 05340.

3The term "petroleum" in this study includes oil, gas, and gas condensate but does not cover natural bitumen and other solid and semisolid derivatives of hydrocarbons.

\section{INTRODUCTION}

The sharply uneven areal and stratigraphic distribution of oil and gas reserves in the world has drawn the attention of petroleum geologists for decades (North, 1979 and 1980; Demaison and Moore, 1980; Curtis, 1980). In earlier times, this phenomenon was thought to be a statistical quirk due to uneven exploration in different parts of the world, which would diminish or even disappear as exploration increased in frontier areas. (See, for example, Levorsen and Berry, 1967). However, during the last 20 years, it has become increasingly obvious that the uneven concentration of oil and gas reserves on any scale (global, continental, basinal) is not a result of our imperfect knowledge, but a fundamental fact of the petroleum geology. Although a few significant regions in the world are as yet unexplored, the main characteristics of the observed distribution of reserves will remain.

Recent advances in organic geochemistry, especially in such areas as maturation of organic matter in sedimentary rocks and oil-to-source rock correlation techniques, have opened up new areas of research. Although the degree of accuracy varies, it is now possible to relate most oil and gas reserves to specific source rocks and to date the periods when the source rocks began to generate oil and/or gas. Thus, the combined effectiveness of oil and gas generation from source rocks and the entrapment and preservation of reservoir pools can be quantitatively measured as the amount of oil and gas that is preserved in the sedimentary fill of a petroleum basin. Such a study on the quantitative distribution of oil source rocks was first attempted by North (1979 and 1980).

In general, the best quantitative measure of resources is that of total original resources of oil and gas in place (discovered and undiscovered). In this study, however, our primary measure is barrels of oil equivalent (BOE) of discovered, original, conventionally recoverable oil and gas reserves, separated into oil and gas where appropriate. For many basins, the quantities of oil and gas in place are difficult to obtain; neither these quantities nor the recovery factors are usually reported. 
Likewise, estimates of undiscovered resources are very subjective and vary significantly as calculated by different authors; their use in this study would only increase the amount of uncertainty. We did not consider unconventional resources of extra heavy oil and bitumen, although they certainly reflect the richness of source rocks, because we consider the mode of formation of these deposits to be, in most cases, very different from that of conventional fields.

Figure 1 shows the effectiveness of source rocks of different ages, as expressed in percents of the world's original oil and gas reserves (in barrels of oil equivalent, BOE) produced by these source rocks. Percent numbers in figure 1 represent a summation of petroleum reserves basin-by-basin (shown in table 2 and on the lithofacies and structural form maps). It is obvious that the statistical distribution of effective source rocks in the stratigraphic column is quite uneven. Six stratigraphic intervals appear to include an overwhelming majority of the world's effective oil and gas source rocks. These stratigraphic intervals are (1) Silurian (LlandoverianPridolian), (2) Upper Devonian-Tournaisian (FrasnianTournaisian), (3) Pennsylvanian-Lower Permian (Bashkirian-Kungurian), (4) Upper Jurassic (Callovian ${ }^{4}$ Tithonian), (5) middle Cretaceous (Aptian-Turonian), and (6) Oligocene-Miocene. These stratigraphic intervals represent only 35.2 percent of Phanerozoic time, but they have generated 91.5 percent of the original reserves of world oil and gas (which total about 2,200 billion BOE). This unevenness of source-rock distribution is sharper if one includes time of deposition of unmetamorphosed Proterozoic strata, the upper part of which (Vendian, Infracambrian, Eocambrian) is widely present in the sedimentary cover of many cratonic areas.

\section{METHODS}

\section{Data Base}

The purpose of this paper is to identify and quantify the main factors controlling the depositional setting, preservation, and effectiveness of hydrocarbon source rocks belonging to the six most important stratigraphic intervals. Maps constructed for each of the six stratigraphic intervals (geologic time slices) illustrate (1) dominant tectonic environments on the continental margins, (2) basic lithofacies composition of the sedimentary sequence, (3) morphic types (structural forms) of the sedimentary basins at the time of sourcerock deposition, (4) quantities and areal distribution of the original reserves of petroleum derived from source

\footnotetext{
${ }^{4}$ Although most U.S. stratigraphers place the Callovian in the Middle Jurassic, it is here included in the Upper Jurassic, as is done in the U.S.S.R. and most of Europe.
}

rocks of the particular stratigraphic interval, and (5) distribution of source rocks by their geochemical types and their current degrees of maturation. Where possible, areas where source rocks have been destroyed by postdepositional geologic processes (such as deformations or metamorphism) are indicated. Plate-tectonic reconstructions of A.M. Ziegler and his associates in the University of Chicago (Scotese and others, 1979; Ziegler and others, 1982) are used as base maps. The Mollweide equal-area projection of the maps significantly distorts the shape of geographic areas; however, it is very convenient for our purposes because it permits simple measurement of areas covered by various rock types. Where necessary, the base maps are modified to show microcontinents that caused deformation at continental margins when they docked with large continental masses.

Data from hundreds of publications on regional geology have been used in construction of the maps. We have not referenced publications on regional tectonics and lithology of the rock units used for preparation of tectonic and lithofacies maps. Such data are highly generalized on our maps, and an interested reader can find these data in numerous publications on regional geology. Many of the structural forms of basins shown on the lithofacies and structural form maps are taken from the same publications on the regional tectonics and structural development of petroleum basins. Many of these data are referred to in table 1 and in the text. For many other areas, we interpreted structural forms using various published cross sections and maps.

Our main concern was to document petroleum source rocks in all basins whose reserves were used for quantitative calculations. We focused on basins in which source rocks in any of the six principal stratigraphic intervals accounted for more than 1 percent of all reserves generated from that interval worldwide. Many basins had source rocks in more than one interval that met this criterion. The basins selected for each stratigraphic interval are listed in table 1. A short description of source rocks of the main petroleum basins is provided in later sections of the text. The degree of certainty of source-rock identification for various basins varies widely. In-depth studies using modern oil-source rock correlation techniques are available for most major petroleum basins. The source of the most complete analysis of each basin is cited. We tried to refer to recent publications that, in turn, refer to and use results of earlier studies. Commonly, the same publications also indicate major reservoir formations that contain presently known oil and gas reserves.

Documentation of source rocks is, in general, significantly poorer for small producing basins and for nonproductive areas (potential source rocks) than for major petroleum basins. Detailed geochemical studies have been conducted in some of them, primarily in the 


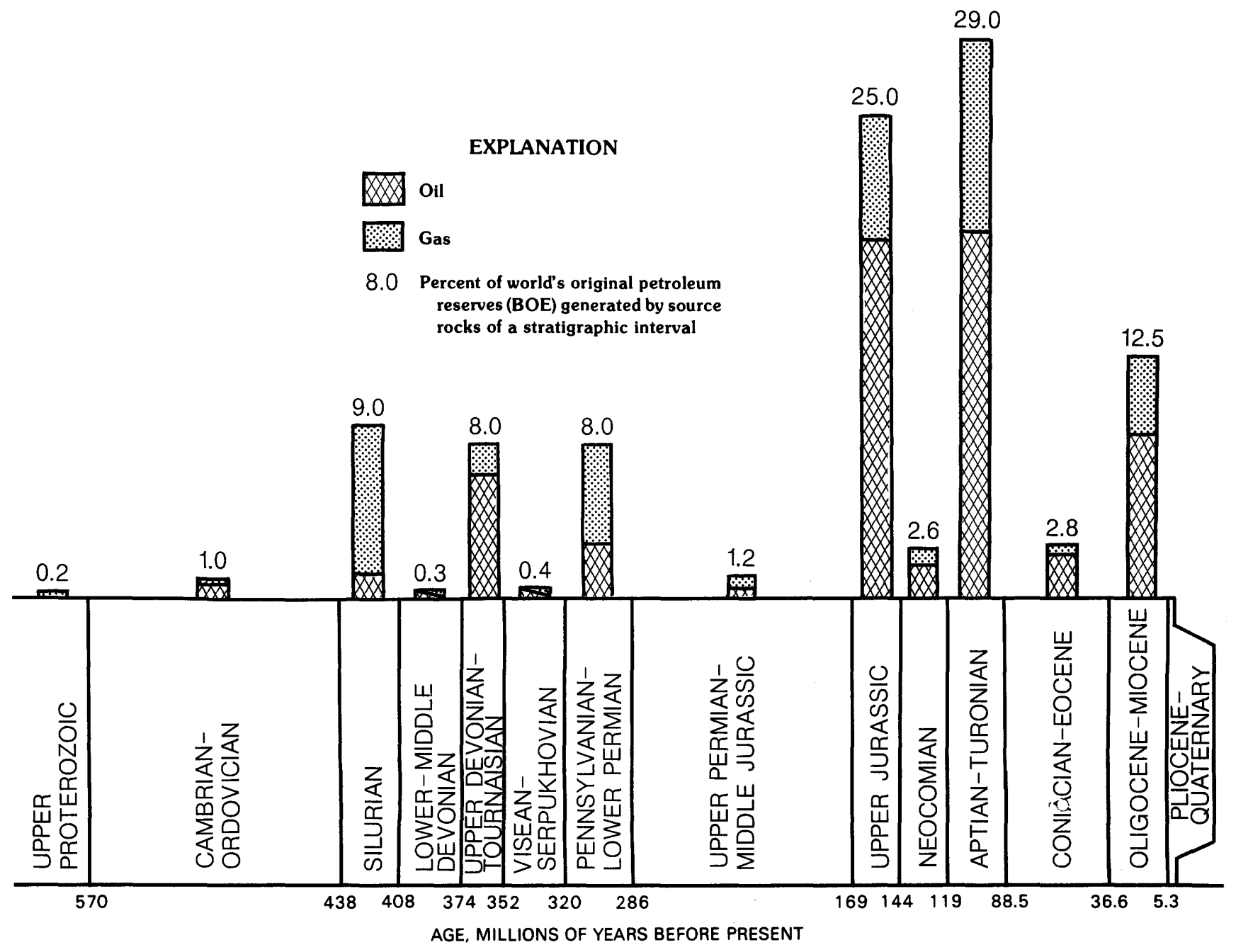

Figure 1. Distribution of effective source rocks through geologic time, in percent of world's original petroleum reserves generated by these rocks. Percent numbers are derived from summation of original petroleum reserves, in barrels of oil equivalent (BOE), of basins shown on the lithofacies and structural forms maps of the six principal stratigraphic intervals. Reserve data for other intervals are approximated from a review of the main basins containing source rocks in these intervals. Separation of the reserves into oil and gas is approximate ( \pm 1 percent).

United States, Canada, and other developed countries. However, in many small basins, the relation of petroleum fields to specific source-rock formations remains a matter of interpretation based on broad geologic analysis. For some of these, we have made our own interpretations; for others, we accepted the published interpretations. Identification of potential source rocks in nonproductive areas is based on lithologic characteristics of sedimentary sections. Primarily, black-shale formations enriched by kerogen types I or II (Tissot and Welte, 1984) and rocks significantly enriched by coaly organic matter (in excess of 2 percent) were classified as potential source rocks.

The original discovered reserves of petroleum include cumulative production and remaining identified reserves. Data on the cumulative production are rather firm and are widely reported in trade, government, and other special publications. Identified reserves are, in general, less certain. They are trustworthy and well reported for the United States (Dolton and others, 1981), Canada (Podruski and others, 1988; Procter and others, 1984), Australia (Forman and others, 1988), the North Sea (Ziegler, 1980), and some other world regions where reserves have been tallied field by field. Remaining and original petroleum reserve amounts in other basins of the world were compiled during the last 10 years by participants of the World Energy Resource Program (WERP) in the U.S. Geological Survey. The primary data that WERP relied upon were foreign government publications (for example, Indian Petroleum and Petrochemical Statistics), published and unpublished assessments of major oil companies (for example, Exxon Corporation, 1982; Roadifer, 1986) and the publications of separate researchers (Riva, 1988; Tanzil, 1985; Ivanhoe, 1985; Nehring, 1978). An important source of data was the field file of Petroconsultants S.A. (Geneva). 
- Table 1. Major productive basins containing source rocks of the six main petroleum-generating intervals

\begin{tabular}{|c|c|c|c|c|c|c|}
\hline $\begin{array}{l}\text { Basin or } \\
\text { province }\end{array}$ & $\begin{array}{l}\text { Structural } \\
\text { form }\end{array}$ & $\begin{array}{l}\text { Source-rock } \\
\text { formation }\end{array}$ & $\begin{array}{l}\text { Dominant } \\
\text { kerogen } \\
\text { type }\end{array}$ & Main reservoirs & $\begin{array}{l}\text { Principal } \\
\text { maturation stage }\end{array}$ & Reference \\
\hline \multicolumn{7}{|c|}{ Basins having Silurian source rocks } \\
\hline Arabian-Iranian & Plat form & $\begin{array}{l}\text { Gahkum and Tabuk Fms; } \\
\text { graptolitic shales. }\end{array}$ & II & $\begin{array}{c}\text { Khuff Fm (Permian); carbo- } \\
\text { nate and clastic rocks. }\end{array}$ & $\begin{array}{l}\text { Late Permian- } \\
\text { Triassic. }\end{array}$ & $\begin{array}{l}\text { Ala and others, } 1980 ; \\
\text { al-Laboun, } 1986 .\end{array}$ \\
\hline $\begin{array}{l}\text { Erg Oriental, } \\
\text { Erg Occidental. }\end{array}$ & Platform & $\begin{array}{l}\text { Silurian graptolitic } \\
\text { shales. }\end{array}$ & II & $\begin{array}{l}\text { Cambrian through Triassic } \\
\text { sandstones. }\end{array}$ & Cretaceous - - - - - & $\begin{array}{l}\text { Tissot, Espitalie, and } \\
\text { others, 1984; Balducchi } \\
\text { and Pommier, 1970; } \\
\text { Magloire, } 1970 .\end{array}$ \\
\hline $\begin{array}{l}\text { Permian, } \\
\text { Anadarko. }\end{array}$ & Plat form & $\begin{array}{l}\text { Silurian marine } \\
\text { shales. }\end{array}$ & II & Silurian carbonate rocks -- & $\begin{array}{l}\text { Pennsylvanian-Early } \\
\text { Permian. }\end{array}$ & Jones and Smith, 1965. \\
\hline Michigan-------- & $\begin{array}{l}\text { Circular } \\
\text { sag. }\end{array}$ & $\begin{array}{l}\text { Niagaran } \mathrm{Fm} \text {, off-reef } \\
\text { carbonate rocks. }\end{array}$ & II & Silurian carbonate rocks -- & $\begin{array}{l}\text { Late Cretaceous- } \\
\text { Early Tertiary(?). }\end{array}$ & Gardner and Bray, 1984 \\
\hline \multicolumn{7}{|c|}{ Basins having Upper Devonian-Tournaisian source roc } \\
\hline $\begin{array}{l}\text { Volga-Ural, } \\
\text { Timan-Pechora, } \\
\text { North Caspian. }\end{array}$ & Platform & $\begin{array}{l}\text { Domanik Fm and } \\
\text { facies equivalents; } \\
\text { marine shales and } \\
\text { carbonate rocks. }\end{array}$ & II & $\begin{array}{l}\text { Middle Devonian sandstones, } \\
\text { Lower Carboniferous sand- } \\
\text { stones, Upper Devonian- } \\
\text { Middle Carboniferous } \\
\text { carbonate rocks. }\end{array}$ & $\begin{array}{l}\text { Late Permian- } \\
\text { Triassic. }\end{array}$ & $\begin{array}{l}\text { Zhuze and others, 1975; } \\
\text { Ashirov and others, } \\
\text { 1981; Ulmishek, 1982; } \\
\text { 1988. }\end{array}$ \\
\hline Alberta -- ---- & Platform & $\begin{array}{l}\text { Duvernay, Ireton, and } \\
\text { Exshaw Fms; marine } \\
\text { shales. }\end{array}$ & II & $\begin{array}{l}\text { Upper Devonian carbonate } \\
\text { rocks. }\end{array}$ & $\begin{array}{l}\text { Middle Cretaceous- } \\
\text { Late Tertiary. }\end{array}$ & $\begin{array}{l}\text { Parsons, 1973; Porter } \\
\text { and others, } 1982 .\end{array}$ \\
\hline $\begin{array}{l}\text { Anadarko, } \\
\text { Permian. }\end{array}$ & Platform & $\begin{array}{l}\text { Woodford Shale; } \\
\text { marine shales. }\end{array}$ & II & $\begin{array}{l}\text { Silurian-Devonian } \\
\text { carbonates. }\end{array}$ & $\begin{array}{l}\text { Pennsylvanian-Early } \\
\text { Permian. }\end{array}$ & $\begin{array}{l}\text { Landes, 1970; Hill, 1971; } \\
\text { Campbe11 and others, } \\
\text { 1988; Jones and Smith } \\
\text { 1965. }\end{array}$ \\
\hline Appalachian ---- & Platform & $\begin{array}{l}\text { Chat tanooga Shale; } \\
\text { marine shales. }\end{array}$ & II & Devonian sandstones -- - - & $\begin{array}{l}\text { Pennsylvanian- } \\
\text { Early Permian. }\end{array}$ & Landes, 1970; Ray, 1971 \\
\hline $\begin{array}{l}\text { Williston, } \\
\text { Michigan, } \\
\text { I11inois. }\end{array}$ & $\begin{array}{l}\text { Circular } \\
\text { sag. }\end{array}$ & $\begin{array}{l}\text { New Albany Shale, } \\
\text { Antrim Shale, } \\
\text { Bakken Fm. }\end{array}$ & II & $\begin{array}{l}\text { Devonian-Pennsylvanian } \\
\text { sandstones and carbonates. }\end{array}$ & $\begin{array}{l}\text { Late Cretaceous- } \\
\text { Early Tertiary(?). }\end{array}$ & $\begin{array}{l}\text { North, 1985; Barrows and } \\
\text { C1uff, 1984; Meissner, } \\
\text { 1984. }\end{array}$ \\
\hline $\begin{array}{l}\text { Pripyat, } \\
\text { Dnieper-Donets. }\end{array}$ & Rift --- & $\begin{array}{l}\text { Upper Devonian- } \\
\text { Tournaisian marine } \\
\text { shales and } \\
\text { carbonate rocks. }\end{array}$ & II & $\begin{array}{l}\text { Upper Devonian carbonate } \\
\text { rocks (Pripyat), Carbon- } \\
\text { iferous-Lower Permian } \\
\text { clastic rocks (Dnieper- } \\
\text { Donets). }\end{array}$ & $\begin{array}{l}\text { Pennsylvanian- } \\
\text { Early Permian. }\end{array}$ & $\begin{array}{l}\text { Chaykovskaya and Volik, } \\
\text { 1986; I1'inskaya and } \\
\text { Kulayeva, } 1979 .\end{array}$ \\
\hline Illizi ------ & Plat form & $\begin{array}{l}\text { Upper and Middle } \\
\text { Devonian marine } \\
\text { shales. }\end{array}$ & II & $\begin{array}{l}\text { Devonian-Carboniferous } \\
\text { sandstones }\end{array}$ & Middle Cretaceous -- & $\begin{array}{l}\text { Tissot, Espitalie, and } \\
\text { others, 1984; Aliyev } \\
\text { and others, 1979. }\end{array}$ \\
\hline
\end{tabular}


Table 1. Major productive basins containing source rocks of the six main petroleum-generating intervals-Continued

\begin{tabular}{|c|c|c|c|c|c|c|}
\hline $\begin{array}{l}\text { Basin or } \\
\text { province }\end{array}$ & $\begin{array}{l}\text { Structural } \\
\text { form }\end{array}$ & $\begin{array}{l}\text { Source-rock } \\
\text { formation }\end{array}$ & $\begin{array}{l}\text { Dominant } \\
\text { kerogen } \\
\text { type }\end{array}$ & Main reservoirs & $\begin{array}{l}\text { Principal } \\
\text { maturation stage }\end{array}$ & Reference \\
\hline \multicolumn{7}{|c|}{ Basins having Pennsylvanian-Lower Permian source rocks } \\
\hline $\begin{array}{l}\text { Anadarko, } \\
\text { Permian. }\end{array}$ & $\begin{array}{l}\text { Foredeep } \\
\quad(\mathrm{SE}) \\
\text { rift } \\
\quad(\mathrm{NW})\end{array}$ & $\begin{array}{l}\text { Pennsylvanian- } \\
\text { Guadalupian } \\
\text { basinal facies, } \\
\text { marine shales. }\end{array}$ & II & $\begin{array}{l}\text { Pennsylvanian-Permian } \\
\text { sandstones and carbonate } \\
\text { rocks. }\end{array}$ & $\begin{array}{l}\text { Late Permian- } \\
\text { middle Cretaceous. }\end{array}$ & $\begin{array}{l}\text { Adler, 1971; Hartman and } \\
\text { Woodard, 1971; Jones } \\
\text { and Smith 1965; Camp- } \\
\text { bell and others, } 1988 .\end{array}$ \\
\hline $\begin{array}{l}\text { Southern North } \\
\text { Sea. }\end{array}$ & Foredeep & $\begin{array}{l}\text { Westphalian coal } \\
\text { measure. }\end{array}$ & III & $\begin{array}{l}\text { Rotliegend (Lower } \\
\text { Permian) sandstones. }\end{array}$ & $\begin{array}{l}\text { Triassic-Middle } \\
\text { Jurassic. }\end{array}$ & Ziegler, 1980. \\
\hline North Caspian -- & $\begin{array}{l}\text { Circular } \\
\text { sag. }\end{array}$ & $\begin{array}{l}\text { Carboniferous-Lower } \\
\text { Permian basinal } \\
\text { facies, marine shales } \\
\text { and carbonate rocks. }\end{array}$ & II & $\begin{array}{l}\text { Carboniferous-Lower Permian } \\
\text { carbonate rocks. }\end{array}$ & $\begin{array}{l}\text { Late Permian- } \\
\text { Triassic. }\end{array}$ & $\begin{array}{l}\text { Fomkin, 1985; Krylov and } \\
\text { Nekhrikova, } 1987 .\end{array}$ \\
\hline $\begin{array}{l}\text { Bighorn, Powder } \\
\text { River, Wind } \\
\text { River, Uinta, } \\
\text { Piceance. }\end{array}$ & $\begin{array}{l}\text { Linear } \\
\text { sag. }\end{array}$ & $\begin{array}{l}\text { Phosphatic shale } \\
\text { members of the } \\
\text { Phosphoria Fm; } \\
\text { marine shales. }\end{array}$ & II & $\begin{array}{l}\text { Pennsylvanian-Permian } \\
\text { sand stones. }\end{array}$ & $\begin{array}{l}\text { Late Cretaceous- } \\
\text { Early Tertiary. }\end{array}$ & $\begin{array}{l}\text { Claypool and others, } \\
\text { 1978; Stauffer, } 1971 \text {; } \\
\text { Cannon, } 1971 ; \text { Peterson } \\
\text { and Smith, 1986. }\end{array}$ \\
\hline Vilyuy ------- & $\begin{array}{l}\text { Circular } \\
\text { sag. }\end{array}$ & $\begin{array}{l}\text { Permian continental } \\
\text { clastic rocks. }\end{array}$ & $\begin{array}{l}\text { III, } \\
\text { coal }\end{array}$ & $\begin{array}{l}\text { Permian to Cretaceous } \\
\text { sand stones. }\end{array}$ & $\begin{array}{l}\text { Jurassic-Early } \\
\text { Cretaceous. }\end{array}$ & Cherskiy, 1986. \\
\hline Sichuan ----- & Platform & $\begin{array}{l}\text { Yangxin Fm; } \\
\text { argillaceous } \\
\text { limestones. }\end{array}$ & II & $\begin{array}{l}\text { Permian-Lower Triassic } \\
\text { carbonate rocks. }\end{array}$ & Middle Cretaceous -- & $\begin{array}{l}\text { Huang, 1984; Wang and } \\
\text { others, 1983; Li and Li } \\
\text { [1984]. }\end{array}$ \\
\hline Cooper - - - - - & Rift -- & $\begin{array}{l}\text { Gidgealpa Group } \\
\text { (Permian); coal } \\
\text { measure. }\end{array}$ & $\begin{array}{l}\text { III, } \\
\text { coal }\end{array}$ & Permian sandstones & Middle Cretaceous -- & $\begin{array}{l}\text { Kantsler and others, } \\
1984 .\end{array}$ \\
\hline \multicolumn{7}{|c|}{ Basins having Upper Jurassic source rocks } \\
\hline Arabian-Iranian & $\begin{array}{l}\text { Linear } \\
\text { sag. }\end{array}$ & $\begin{array}{l}\text { Hanifa, Diyal/Dukhan, } \\
\text { and Sargelu Fms; } \\
\text { marine shales, } \\
\text { marls, and } \\
\text { limestones. }\end{array}$ & II & $\begin{array}{l}\text { Arab Zone (Upper Jurassic) } \\
\text { and Shuaiba (middle } \\
\text { Cretaceous) carbonate } \\
\text { rocks. }\end{array}$ & $\begin{array}{l}\text { Late Cretaceous } \\
\text { and Late Tertiary. }\end{array}$ & $\begin{array}{l}\text { Ayres and others, 1982; } \\
\text { Klemme, 1984; Alshar- } \\
\text { han, 1987; Alsharhan } \\
\text { and Kenda11, 1986; } \\
\text { Murris, 1980; Koop and } \\
\text { Stoneley, 1982. }\end{array}$ \\
\hline West Siberian -- & $\begin{array}{l}\text { Circular } \\
\text { sag. }\end{array}$ & $\begin{array}{l}\text { Bazhenov Fm; marine } \\
\text { siliceous shales } \\
\text { and carbonate rocks. }\end{array}$ & II & $\begin{array}{l}\text { Neocomian deltaic } \\
\text { sandstones. }\end{array}$ & $\begin{array}{l}\text { Late Cretaceous- } \\
\text { Early Tertiary. }\end{array}$ & $\begin{array}{l}\text { Stasova, 1977; Ivantsova, } \\
\text { 1969; Kulikov, 1979; } \\
\text { Kontorovich and others, } \\
\text { 1975. }\end{array}$ \\
\hline $\begin{array}{l}\text { North Sea, } \\
\text { Greenland Sea. }\end{array}$ & $\begin{array}{l}\text { Linear } \\
\text { sag. }\end{array}$ & $\begin{array}{l}\text { Kimmeridgian Shale, } \\
\text { marine siliceous } \\
\text { shales. }\end{array}$ & II & $\begin{array}{l}\text { Middle Jurassic sandstones, } \\
\text { Upper Cretaceous-Lower } \\
\text { Tertiary chalk and } \\
\text { sandstones. }\end{array}$ & Early Tertiary - & $\begin{array}{l}\text { Ziegler, 1980; Cooper and } \\
\text { Barnard, 1984; Goff, } \\
\text { 1984; Baird, 1986. }\end{array}$ \\
\hline
\end{tabular}


- Table 1. Major productive basins containing source rocks of the six main petroleum-generating intervals-Continued

\begin{tabular}{|c|c|c|c|c|c|c|}
\hline $\begin{array}{l}\text { Basin or } \\
\text { province }\end{array}$ & $\begin{array}{l}\text { Structural } \\
\text { form }\end{array}$ & $\begin{array}{l}\text { Source-rock } \\
\text { formation }\end{array}$ & $\begin{array}{l}\text { Dominant } \\
\text { kerogen } \\
\text { type }\end{array}$ & Main reservoirs & $\begin{array}{l}\text { Principal } \\
\text { maturation stage }\end{array}$ & Reference \\
\hline \multicolumn{7}{|c|}{ Basins having Upper Jurassic source rocks--Continued } \\
\hline $\begin{array}{l}\text { Gulf of Mexico } \\
\text { (Gulf Coast, } \\
\text { Reforma-Cam- } \\
\text { peche, Tampico- } \\
\text { Chicontepec). }\end{array}$ & $\begin{array}{c}\text { Circular } \\
\text { sag. }\end{array}$ & $\begin{array}{l}\text { Kimmeridgian- } \\
\text { Tithonian marine } \\
\text { shales and } \\
\text { carbonate rocks. }\end{array}$ & II & $\begin{array}{l}\text { Upper Jurassic carbonate } \\
\text { and Lower Cretaceous } \\
\text { clastic rocks (Gulf } \\
\text { Coast); Cretaceous reefs, } \\
\text { Eocene-Miocene sandstones. }\end{array}$ & $\begin{array}{l}\text { Middle Cretaceous } \\
\text { (Gulf Coast); } \\
\text { Late Tertiary. }\end{array}$ & $\begin{array}{l}\text { Salvador and Green, } 1980, \\
\text { Peters on, 1983, 1985; } \\
\text { Salvador, 1987; Oehler, } \\
\text { 1984. }\end{array}$ \\
\hline $\begin{array}{l}\text { North Caucasus, } \\
\text { Amu-Darya. }\end{array}$ & $\begin{array}{l}\text { Linear } \\
\text { sag. }\end{array}$ & $\begin{array}{l}\text { Khodzhaipak Fm; Upper } \\
\text { Jurassic rocks } \\
\text { below salt layer; } \\
\text { marine shales and } \\
\text { limestones. }\end{array}$ & II & $\begin{array}{l}\text { Upper Jurassic limestones, } \\
\text { Cretaceous sandstones } \\
\text { and limestones. }\end{array}$ & Late Tertiary - & $\begin{array}{l}\text { Akramkhodzhayev and Egam- } \\
\text { berdyev, 1985; Maksimov } \\
\text { and others, 1986; } \\
\text { Krylov, 1979; Semashev, } \\
\text { 1983; Chakhmakhchev and } \\
\text { others, 1987; Seregin } \\
\text { and others, 1982. }\end{array}$ \\
\hline
\end{tabular}

\begin{tabular}{|c|c|c|c|c|c|c|}
\hline & & Basin & having & middle Cretaceous source roc & & \\
\hline Arabian-Iranian & $\begin{array}{l}\text { Linear } \\
\text { sag. }\end{array}$ & $\begin{array}{l}\text { Kazhdumi Fm; marine } \\
\text { shales and } \\
\text { limestones. }\end{array}$ & II & $\begin{array}{l}\text { Asmari limestone (Miocene), } \\
\text { Burgan delta (early- } \\
\text { middle Cretaceous). }\end{array}$ & Middle-late Tertiary & $\begin{array}{l}\text { Hu11 and Warman, 1970; } \\
\text { James and Wynd, 1965; } \\
\text { Dunnington, 1958, 1967; } \\
\text { Ala and others, 1980; } \\
\text { Murris, 1980; Koop and } \\
\text { Stoneley, 1982. }\end{array}$ \\
\hline Maracaibo ----- & $\begin{array}{l}\text { Linear } \\
\text { sag. }\end{array}$ & $\begin{array}{l}\text { La Luna Fm; marine } \\
\text { shales and } \\
\text { limestones. }\end{array}$ & II & Eocene-Miocene sandstones & Late Tertiary - - & $\begin{array}{l}\text { Zambrano and others, } \\
\text { 1972; Blaser and White, } \\
\text { 1984. }\end{array}$ \\
\hline $\begin{array}{l}\text { East Venezuela, } \\
\text { Middle Magda- } \\
\text { lena, Llanos } \\
\text { Oriente. }\end{array}$ & $\begin{array}{l}\text { Linear } \\
\text { sag. }\end{array}$ & $\begin{array}{l}\text { Querecual and La Luna } \\
\text { Fms; marine shales } \\
\text { and limestones. }\end{array}$ & II & Eocene-Miocene sandstones & Late Tertiary - - -- & $\begin{array}{l}\text { Hedberg, 1950; Krause, } \\
\text { 1988; McCollough and } \\
\text { Padfield, 1985; } \\
\text { Zumberge, 1984. }\end{array}$ \\
\hline $\begin{array}{l}\text { Alberta, } \\
\text { Overthrust, } \\
\text { Green River. }\end{array}$ & Foredeep & $\begin{array}{l}\text { Mannville marine } \\
\text { shales and } \\
\text { equivalents. }\end{array}$ & III & Cretaceous sandstones --- & Late Tertiary - - & $\begin{array}{l}\text { Parsons, 1973; Moshier } \\
\text { and Waples, } 1985 .\end{array}$ \\
\hline Gulf Coast - & $\begin{array}{l}\text { Circular } \\
\text { sag. }\end{array}$ & Marine shales - - - & II & $\begin{array}{l}\text { Cretaceous carbonates and } \\
\text { sandstones. }\end{array}$ & Late Tertiary - - & $\begin{array}{l}\text { Rainwater, } 1971 ; \\
\text { Holcomb, } 1971 .\end{array}$ \\
\hline $\begin{array}{l}\text { Amu-Darya, North } \\
\text { Caucasus, } \\
\text { Crimea. }\end{array}$ & $\begin{array}{l}\text { Linear } \\
\text { sag. }\end{array}$ & $\begin{array}{l}\text { Aptian-Albian marine } \\
\text { shales. }\end{array}$ & II & Cretaceous sandstones --- & Late Tertiary - & $\begin{array}{l}\text { Arkhipov and others, } \\
\text { 1979; Mirzoyev and } \\
\text { Dzhaparidze, 1979; } \\
\text { Shestopal, 1979; Maksi- } \\
\text { mov and others, } 1987 .\end{array}$ \\
\hline
\end{tabular}


Table 1. Major productive basins containing source rocks of the six main petroleum-generating intervals-Continued

\begin{tabular}{|c|c|c|c|c|c|c|}
\hline $\begin{array}{l}\text { Basin or } \\
\text { province }\end{array}$ & $\begin{array}{l}\text { Structural } \\
\text { form }\end{array}$ & $\begin{array}{l}\text { Source-rock } \\
\text { formation }\end{array}$ & $\begin{array}{l}\text { Dominant } \\
\text { kerogen } \\
\text { type }\end{array}$ & Main reservoirs & $\begin{array}{l}\text { Principal } \\
\text { maturation stage }\end{array}$ & Reference \\
\hline \multicolumn{7}{|c|}{ Basins having middle Cretaceous source rocks--Continued } \\
\hline $\begin{array}{l}\text { South Atlantic } \\
\text { basins. }\end{array}$ & $\begin{array}{l}\text { Rift/ } \\
\text { linear } \\
\text { sag. }\end{array}$ & $\begin{array}{l}\text { Upper Neocomian-Aptian } \\
\text { lacustrine and } \\
\text { marine shales; Turo- } \\
\text { nian marine shales. }\end{array}$ & I, II & $\begin{array}{l}\text { Cretaceous sandstones and } \\
\text { carbonates; Tertiary } \\
\text { sandstones. }\end{array}$ & $\begin{array}{l}\text { Late Cretaceous- } \\
\text { Early Tertiary. }\end{array}$ & $\begin{array}{l}\text { Ponte and others, } 1980 ; \\
\text { Clifford, 1986; Lehner } \\
\text { and De Ruiter, } 1977\end{array}$ \\
\hline $\begin{array}{l}\text { West Siberia } \\
\text { (northern). }\end{array}$ & $\begin{array}{l}\text { Circular } \\
\text { sag. }\end{array}$ & $\begin{array}{l}\text { Pokur Fm (Albian- } \\
\text { Cenomanian); } \\
\text { continental } \\
\text { clastic rocks. }\end{array}$ & $\begin{array}{l}\text { III } \\
\text { coal }\end{array}$ & $\begin{array}{l}\text { Albian-Cenomanian } \\
\text { sandstones. }\end{array}$ & Immature - & $\begin{array}{l}\text { Nesterov and others, } \\
\text { 1978; Rice and } \\
\text { Claypool, 1981; } \\
\text { Kortsenshteyn, } 1970 ; \\
\text { Grace and Hart, } 1986 .\end{array}$ \\
\hline North Slope --- & Foredeep & $\begin{array}{l}\text { HRZ shale, Hue Shale; } \\
\text { marine shales. }\end{array}$ & III & Cretaceous sandstones - - & $\begin{array}{l}\text { Late Cretaceous- } \\
\text { Early Tertiary. }\end{array}$ & $\begin{array}{l}\text { Carman and Hardwick, } \\
1983 ; \text { Molenaar and } \\
\text { others, 1987; Bird } \\
\text { and Magoon, 1987. }\end{array}$ \\
\hline Song11ao ---- & $\begin{array}{l}\text { Linear } \\
\text { sag. }\end{array}$ & $\begin{array}{l}\text { Qingshankou and } \\
\text { Nenjiang Fms; deep } \\
\text { lacustrine shales. }\end{array}$ & I & $\begin{array}{l}\text { Cretaceous deltaic } \\
\text { sandstones. }\end{array}$ & $\begin{array}{l}\text { Late Cretaceous- } \\
\text { Early Tertiary. }\end{array}$ & $\begin{array}{l}\text { Yang and others, 1985; } \\
\text { Zhou, 1985; Yang, } 1985 .\end{array}$ \\
\hline \multicolumn{7}{|c|}{ Basins having } \\
\hline $\begin{array}{l}\text { East Venezuela- } \\
\text { Trinidad, } \\
\text { Maracaibo. }\end{array}$ & Foredeep & $\begin{array}{l}\text { Oficina Fm and equi- } \\
\text { valents, deltaic } \\
\text { and prodeltaic } \\
\text { shales. }\end{array}$ & $\begin{array}{c}\text { III } \\
\text { (west) } \\
\text { II } \\
\text { (east) }\end{array}$ & Miocene-P1iocene sandstones & Late Tertiary - - - & $\begin{array}{l}\text { Michelson, 1976; Blaser } \\
\text { and White, } 1984 .\end{array}$ \\
\hline Niger Delta --- & Delta -- & $\begin{array}{l}\text { Akata and Agbada Fms; } \\
\text { deltaic shales. }\end{array}$ & $\begin{array}{l}\text { III } \\
\text { coal }\end{array}$ & $\begin{array}{l}\text { Upper Tertiary deltaic } \\
\text { sandstones. }\end{array}$ & Late Tertiary - - - & $\begin{array}{l}\text { Ejed awe and others, 1984; } \\
\text { Nwachukwu and Chukwura, } \\
\text { 1986; Bustin, 1988. }\end{array}$ \\
\hline Mackenzie Delta- & Delta -- & $\begin{array}{l}\text { Tertiary deltaic } \\
\text { shales. }\end{array}$ & III & $\begin{array}{l}\text { Upper Tertiary de1taic } \\
\text { sandstones. }\end{array}$ & Late Tertiary ----- & $\begin{array}{l}\text { Snowd on, 1980; Snowdon } \\
\text { and Powe11, } 1982 .\end{array}$ \\
\hline Mahakam Delta -- & De1ta -- & $\begin{array}{l}\text { Miocene deltaic } \\
\text { shales. }\end{array}$ & $\begin{array}{l}\text { III, } \\
\text { coal }\end{array}$ & $\begin{array}{l}\text { Upper Tertiary deltaic } \\
\text { sandstones. }\end{array}$ & Late Tertiary ----- & $\begin{array}{l}\text { Combaz and de Matherel, } \\
1978 \text {. }\end{array}$ \\
\hline $\begin{array}{l}\text { Californian } \\
\text { basins. }\end{array}$ & Rift --- & $\begin{array}{l}\text { Monterey Fm; diatoma- } \\
\text { ceous shale. }\end{array}$ & II & $\begin{array}{l}\text { Upper Tertiary sandstones } \\
\text { and shales. }\end{array}$ & Late Tertiary - - - & $\begin{array}{l}\text { Graham and Williams, } \\
\text { 1985; Crain and } \\
\text { others, } 1985 .\end{array}$ \\
\hline $\begin{array}{l}\text { Gulf Coast and } \\
\text { Mississippi } \\
\text { Delta. }\end{array}$ & $\begin{array}{l}\text { Half sag } \\
\text { and } \\
\text { delta. }\end{array}$ & $\begin{array}{c}\text { Tertiary marine and } \\
\text { deltaic shales. }\end{array}$ & III & Tertiary sandstones - & $\begin{array}{l}\text { Late Tertiary and } \\
\text { immature. }\end{array}$ & $\begin{array}{l}\text { Tipsword and others, } \\
1971 \text {; Dow, 1978; Rice } \\
\text { and Claypoo1, 1981. }\end{array}$ \\
\hline
\end{tabular}




\begin{tabular}{|c|c|c|c|c|c|c|}
\hline $\begin{array}{l}\text { Basin or } \\
\text { province }\end{array}$ & $\begin{array}{l}\text { Struct }{ }^{\prime} \text { ral } \\
\text { form }\end{array}$ & $\begin{array}{l}\text { Source-rock } \\
\text { formation }\end{array}$ & $\begin{array}{l}\text { Dominant } \\
\text { kerogen } \\
\text { type }\end{array}$ & Main reservoirs & $\begin{array}{l}\text { Principal } \\
\text { maturation stage }\end{array}$ & Reference \\
\hline \multicolumn{7}{|c|}{ Basins having Oligocene-Miocene source rocks--Continued } \\
\hline $\begin{array}{l}\text { Indonesian } \\
\text { basins. }\end{array}$ & Rift - - - & $\begin{array}{c}\text { Pematang Brown Shale } \\
\text { and Banuwati Shale, } \\
\text { lacustrine shales. } \\
\text { Talang-Akar Fm, flu- } \\
\text { viodeltaic shales. }\end{array}$ & $\begin{array}{l}\text { I } \\
\text { III, } \\
\text { coal }\end{array}$ & Upper Tertiary sandstones & Late Tertiary & $\begin{array}{l}\text { Kingston, } 1979 ; \\
\text { Robinson, 1987; } \\
\text { Gordon, } 1985 .\end{array}$ \\
\hline $\begin{array}{l}\text { North Kalimantan } \\
\text { (Baram Delta). }\end{array}$ & Delta --- & $\begin{array}{l}\text { Miocene deltaic } \\
\text { shales. }\end{array}$ & III & Upper Tertiary sandstones & Late Tertiary $\rightarrow \cdots$ & ASCOPE, 1981 \\
\hline $\begin{array}{l}\text { North China, } \\
\text { Biyang, } \\
\text { Nanxiang, } \\
\text { Jianghan. }\end{array}$ & Rift ---- & Lacustrine shales --- & I & $\begin{array}{l}\text { Upper Tertiary sandstones, } \\
\text { Sinian carbonate rocks. }\end{array}$ & Late Tertiary & $\begin{array}{l}\text { Lao and Gao, 1984; Li } \\
\text { Desheng and others, } \\
1984 ; \text { Zha, 1984; Huang } \\
\text { and others, 1984; Tong, } \\
1980 ; \text { Li Chunju and } \\
\text { others, } 1984 .\end{array}$ \\
\hline South Caspian -- & $\begin{array}{l}\text { Circular } \\
\text { sag. }\end{array}$ & $\begin{array}{l}\text { Maykop Series and } \\
\text { middle Mioocene } \\
\text { marine shales. }\end{array}$ & II & Pliocene sandstones - - & Late Tertiary - & $\begin{array}{l}\text { Ali-Zade and others, } \\
\text { 1975; Korchagina and } \\
\text { Zeynalova, 1986. }\end{array}$ \\
\hline North Caucasus & Foredeep & $\begin{array}{l}\text { Maykop Series and } \\
\text { middle Miocene } \\
\text { marine shales. }\end{array}$ & II & Upper Tertiary sandstones & Late Tertiary & $\begin{array}{l}\text { Burlakov and others, } \\
\text { 1987; Shcherbakov and } \\
\text { others, 1983; Chepak } \\
\text { and others, 1983. }\end{array}$ \\
\hline Suez - - & Rift ---- & $\begin{array}{l}\text { Rudies Fm; } \\
\text { marine shales. }\end{array}$ & II & $\begin{array}{l}\text { Cretaceous to Miocene } \\
\text { sandstones and } \\
\text { carbonate rocks. }\end{array}$ & Late Tertiary ------ & $\begin{array}{l}\text { Kholief and Baroket, } \\
\text { 1986. }\end{array}$ \\
\hline $\begin{array}{l}\text { Carpathian } \\
\text { (Ploiesti and } \\
\text { western } \\
\text { Ukraine). }\end{array}$ & Fored eep & $\begin{array}{l}\text { Menelitic Shale, } \\
\text { marine shales. }\end{array}$ & II & Upper Tertiary sandstones & Late Tertiary - & $\begin{array}{l}\text { Paraschiv and Ol teanu, } \\
\text { 1970; Gavrish, } 1985 .\end{array}$ \\
\hline
\end{tabular}

${ }_{2}^{1}$ Structural form that controlled deposition of source rocks.

${ }^{2}$ of Tissot and Welte (1984). 
Approximately 80 percent of world reserves, listed field by field, have been examined from geologic and engineering points of view by W.D. Dietzman and his colleagues with the U.S. Energy Information Administration. Some of their studies have been published in a series of reports (U.S. Department of Energy and U.S. Geological Survey, 1979; U.S. Energy Information Administration, 1983a, b, c). Together with other members of the World Energy Resource Program, we analyzed available assessments of the world's remaining petroleum reserves. For the countries that consider petroleum reserves to be classified information (such as the U.S.S.R. and China), we made a basin-by-basin assessment of reserves based on available petroleum geology and production data. Our group's assessments of identified reserves were reported by C.D. Masters and others (1987) on a country basis, although the original assessments were developed by basins. Original reserve numbers that we have accepted for all basins of interest are listed in table 2. The basins listed here are those whose source rocks account for more than 1 percent of reserves generated from at least one of the six principal stratigraphic intervals.

The assignment of original oil and gas reserves to a specific source rock was not a problem for most basins, where only one source-rock formation had generated all or nearly all of the petroleum. Some petroleum basins, chiefly the largest ones such as the Arabian-Iranian, West Siberian, and Greater Permian basins, contain more than one source-rock formation. However, in almost all cases, the main parts of reserves generated by each source-rock formation are areally and/or stratigraphically separated; thus each formation's contribution may be evaluated based on the same reserve data that were used to assess the basin's reserves. Petroleum reserve numbers shown on the maps are rounded to the nearest whole percent. Values corresponding to 1 percent vary from $1.75 \times 10^{9} \mathrm{BOE}$ on the Pennsylvanian-Lower Permian and Upper Devonian-Tournaisian maps to $6.4 \times 10^{\circ} \mathrm{BOE}$ on the middle Cretaceous map. We believe that for the majority of basins, the precision of our reserve assessment falls into these ranges. However, some inaccuracies were unavoidable considering the global nature of the study. We believe that these possible inaccuracies have very little, if any, effect on the main conclusions resulting from this study.

\section{Classification of Petroleum Basins}

Several petroleum basin classifications based on tectonic principles have been proposed in recent years (Bally and Snelson, 1980; Sokolov, 1980; Bois and others, 1982; Klemme, 1971, 1980, 1983; Kingston and others,
Table 2. Original petroleum reserves of major productive basins shown on the maps

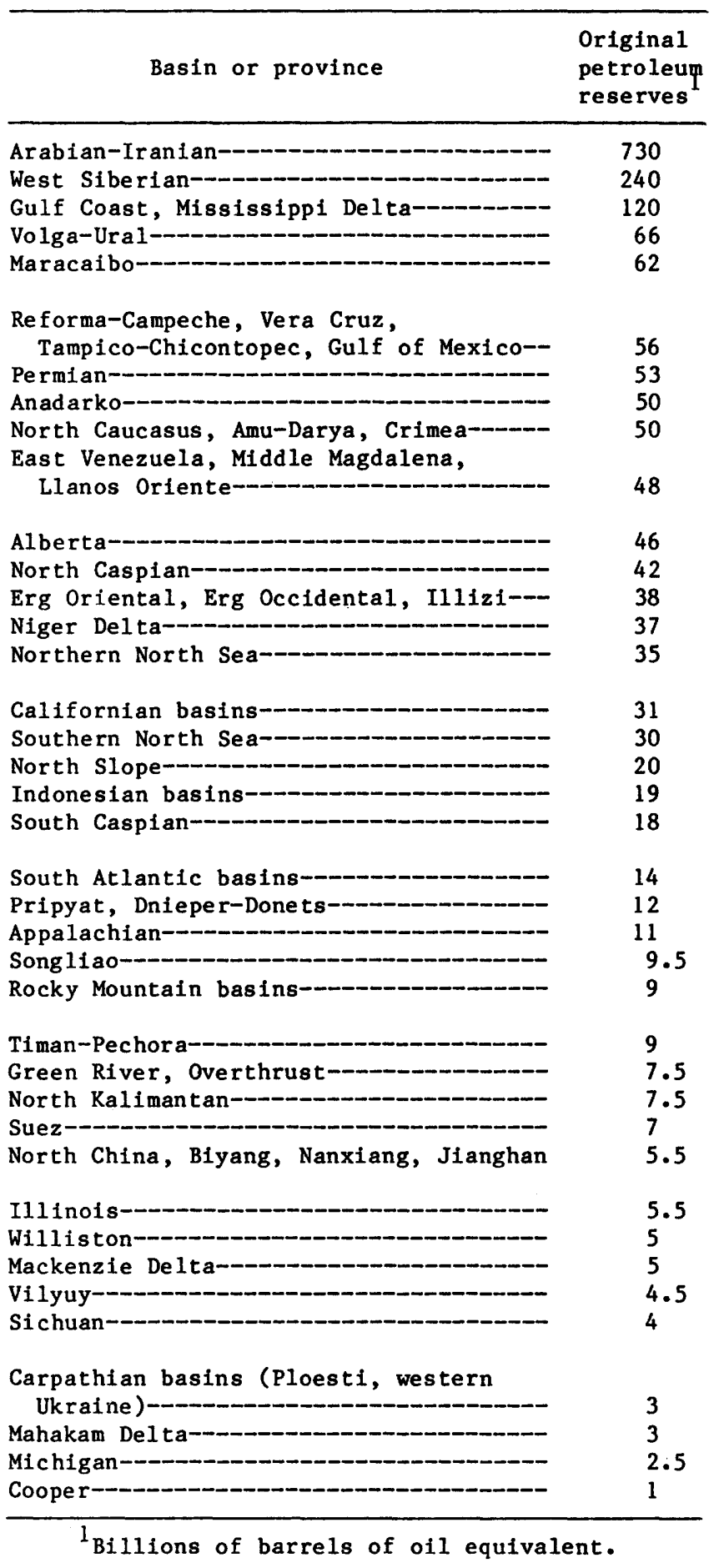

1983; and others). These classifications differ from one another primarily in their varied emphasis on such factors as geodynamic regimes, basin structural profiles, positions of the basins on continents, and tectonic stages in basin development. In this study we use the 
classification of Klemme that is shown in figure 2. This classification is considerably modified from Klemme's previous (1980) classification; however, a detailed description of it is beyond the scope of this paper. The classification is based on (1) the position of a basin within major geotectonic areas (cratons, accreted zones, and convergent and divergent margins) and (2) the sequence of structural forms that reflects the basin's tectonic evolution. The plate tectonic setting largely determines a basin's geologic history and results in a specific basin structural profile. Structural expressions of basins in different stages of their development strongly affected the deposition of source rocks within the basin. The subsequent tectonic history of a basin (overlying structural forms) controlled maturation of the source rocks, formation of hydrocarbon pools, and their preservation or destruction.

\section{Tectonic Maps}

A tectonic map for each of the selected time intervals (part $A$ on pls. 1-6) shows the main characteristics of the tectonic regime on the continental margins. Two main geotectonic processes, divergence and convergence of crustal plates, gave rise to passive and active continental margins. Several principal features of the active margins significantly affected the structural (morphotectonic) forms of depositional basins along the margins, and these forms in turn controlled the nature of sedimentation. Oceanic volcanic arcs separated fore-arc and back-arc basins and supplied abundant volcanic material to the associated sediments. Transverse and longitudinal rifts and median (intermontane) basins commonly formed following the development of continental magmatic arcs along B-subduction zones (Bally and Snelson, 1980). Also shown on the active margins are the docking of microcontinents onto the large continental massifs and continent-to-continent collisions. Both processes resulted in deformation at the margins, orogenies, the formation of rifted basins as relaxation features at trailing edge of the collision zones, and the development of foredeeps.

Passive margins are characterized by widespread rifting followed by the formation of morphologically varying sags over rifts. Large, thick deltas that formed along these margins created an environment highly favorable for the generation and entrapment of hydrocarbons. Of these, only the late Mesozoic and Tertiary deltas have been preserved; older ones were destroyed by subsequent tectonic activity. Young deltas are also known from active margins, where they are mainly found along marginal seas. The tensional regime along the margins of these seas is rather similar to that of passive margins in that both extensional rifting and wrench rifting occur. This tensional episode, however, is ephemeral in the geologic history of active margins; therefore, the associated deltas are preserved only along the Cenozoic margins.

Additional features shown on each tectonic map include the region of sedimentation and, for the two youngest stratigraphic intervals, the area of oceanic crust formed during the immediately preceding time period (Early Cretaceous for the middle Cretaceous and latest Cretaceous-early Tertiary for the Oligocene-Miocene map).

\section{Lithofacies and Structural Form Maps}

The lithofacies and structural form maps (part $B$ on pls. 1-6) illustrate the general facies for the stratigraphic intervals. Three facies are distinguished herein: dominantly marine, dominantly continental, and mixed marine and continental lithofacies. The degree of simplification stems from the global nature of the study, the relatively large stratigraphic range of each interval, and the broad requirements of the analysis. However, this simplified version of the facies composition correlates with the character of petroleum source rocks as shown on the source-rock maps.

Most basins in the course of their development passed through different tectonic stages. These tectonic stages are expressed as successive structural (architectural, morphotectonic) forms. Taken together, structural forms constitute a basin's structural profile, which is diagnostic of each basin type. Generalized basin profiles are shown in figure 2. Basin types are not shown on the maps; however, the structural forms that existed during the corresponding stratigraphic interval are indicated. These structural forms controlled the deposition of source rocks, their thickness, and their areal extent. A given structural form (for example, rifts) might exist in a number of areas during a specific time interval, but then variations in the subsequent tectonic histories of the areas can cause the form to be incorporated into the profiles of several different basin types. This subsequent tectonic history of each area affects the burial and maturation of source rocks, and their destruction. Thus, the tectonic history controls the effectiveness of source rocks as suppliers of oil and gas to reservoirs. The number of basic structural forms is rather restricted, although the dimensions and depths of individual structures can vary significantly. The basic structural forms shown on the maps are platforms, rifts, circular sags, linear sags, half sags, foredeeps, and deltas (depocenters). Wherever evidence was insufficient to show whether a sag is circular or linear, the structure was merely designated a sag. All other structural forms invariably have distinct morphologic differences. 


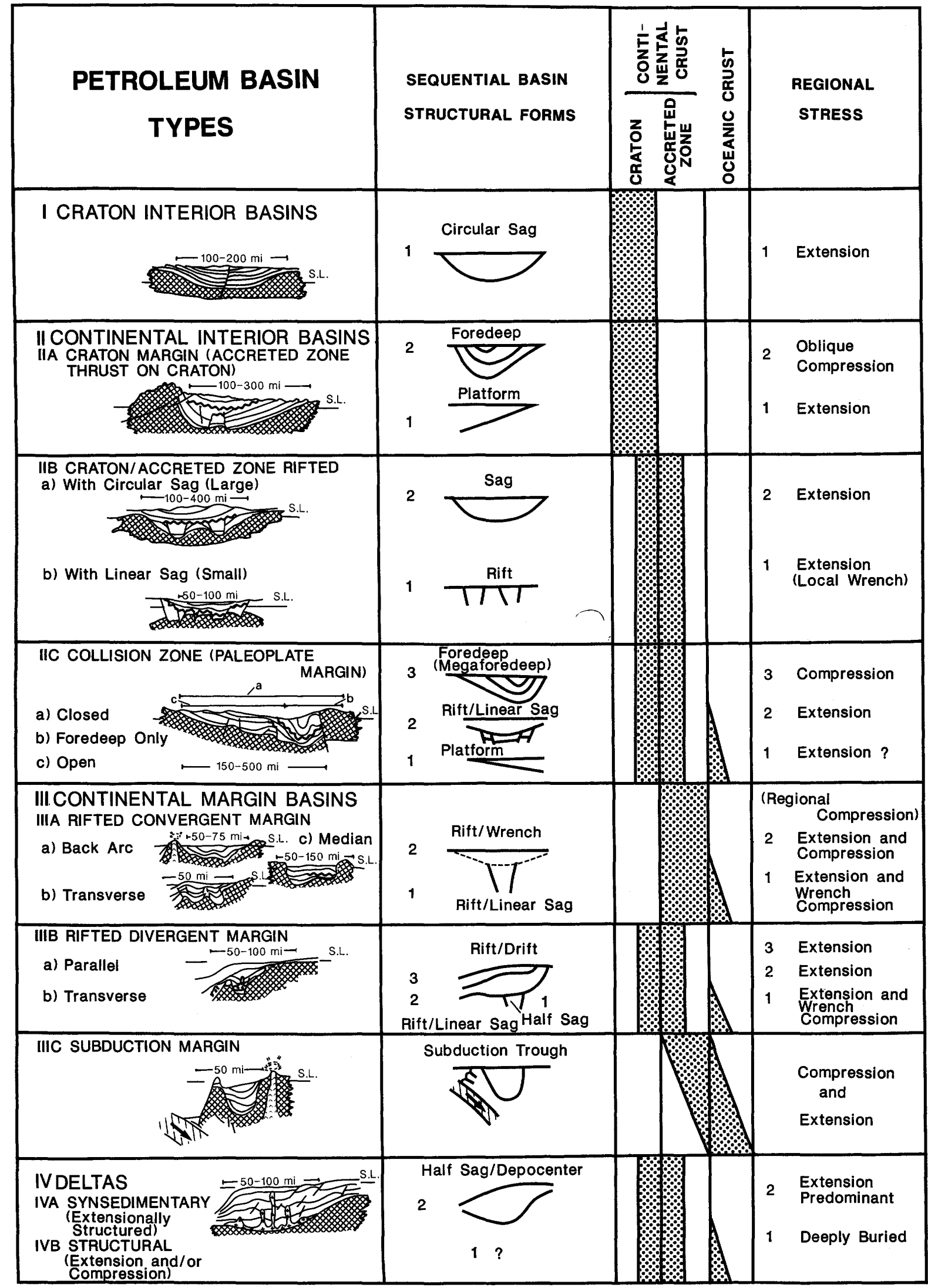

Figure 2. Basin classification scheme used in this report. The classification is based on the position of a basin within major geotectonic areas (shown by shading in column 3 ) and the sequence of structural forms that reflects the basin's tectonic evolution (shown in column 2). 
Each structural form is characterized by the morphology of a sedimentary body deposited in the structure. Platforms are characterized by areally large sheets of relatively thin sedimentary rocks on cratons and less commonly on accreted zones (epi-platforms). The strata dip very gently toward the ocean. Linear sags are strongly elongated depressions with gently sloping limbs. They are most commonly formed over single rifts. Circular sags are commonly larger than linear sags. They usually overlie branching rift systems (randomly oriented). Circular sags also include structures developed over basaltic windows in continental crust (small ocean basins) filled with sediments. Half sags are asymmetric sedimentary bodies composed of the seaward-prograding wedges of clastic rocks and carbonate bank sediments. They formed on passive continental margins or at the edges of rifted continental blocks in marginal seas. Rifts are linear, commonly rather narrow horst-and-graben depressions bounded by deep-seated faults. They are developed on cratons, in accreted zones, and sometimes in orogenic belts. A foredeep is an asymmetric trough developed between an orogenic belt and a foreland that is largely filled with molasse deposits derived from the orogen. The deepest part of the trough is shifted toward the orogen, which in turn is thrust upon sedimentary rocks of an earlier foredeep stage. Deltas (depocenters) in this study are very thick sedimentary bodies located on the continental margins (commonly along a triple junction). Some deltas are similar to half sags, but because of great sedimentary loading, deltas usually develop a partially closed central sag. Half sags, on the contrary, are generally open to the ocean. Other deltas may be structurally confined (for example, the Po Delta).

The structural form and lithofacies maps also show the approximate outlines of the present-day petroleum basins that contain discovered oil and gas generated by source rocks of the mapped stratigraphic interval. These basins are numbered and listed on the maps. Oil and gas may be confined to rocks of the same stratigraphic interval or may have migrated to rocks of other parts of the section. The amount of original oil and gas reserves (calculated in barrels of oil equivalent, BOE) is shown as a percentage of all oil and gas generated worldwide by source rocks of the same stratigraphic interval and trapped in the discovered fields. In basins where the discovered reserves equal less than 1 percent, the reserves are designated as minor $(\mathrm{M})$. The maps also record the amount of discovered original reserves generated by source rocks of a given stratigraphic interval in each of the structural forms that controlled deposition of these source rocks.

\section{Source-Rock Maps}

Source-rock maps of each stratigraphic interval (part $C$ on pls. 1-6) show the character and maturity of petroleum source rocks. The basis for distinguishing petroleum source rocks from non-source rocks was the reported amount and quality (kerogen type) of organic matter and, where available, oil-source rock correlation information. The source rocks shown on the maps include both those that generated reserves in discovered fields (effective source rocks) and those that did not (potential source rocks). The latter group includes those source rocks that for different geologic reasons either did not generate petroleum or produced petroleum accumulations that have since been destroyed. In addition, the reserve occurrence data from the structural form and facies maps are shown on the source-rock maps. The numbers (in percentage points) document the effectiveness of hydrocarbon generation, entrapment, and preservation. (On the source-rock maps, the numbers relate to areas of source-rock distribution rather than to basins and structural forms.)

All source rocks are subdivided into those with predominant types I and II kerogen (oil-prone) and those containing predominant type III kerogen and coal, according to classification of Tissot and Welte (1984). The main petroleum-generative fraction of coal is also represented by type III kerogen. Where both kerogen groups dominate different parts of the same stratigraphic interval, the more important group responsible for the petroleum occurrence is shown. In most cases, source rocks with types I and II kerogen appear to be more important. One of the few exceptions is Pennsylvanian coal of northwestern Europe, which has generated much more trapped petroleum than have the younger Zechstein black shales and carbonates with type II kerogen. In nonproductive areas, primarily black-shale formations enriched by type II kerogen and rocks significantly enriched by coaly organic matter (in excess of 1.5-2 percent) were classified as potential source rocks.

All source rocks are subdivided into those that have attained or surpassed maturity and those that are still immature. Overmature source rocks are grouped with mature because they are still capable of generating gas, although overmaturation certainly decreases hydrocarbon potential. Additionally, overmature source rocks did generate oil and gas earlier in their geologic history, which may have migrated to shallower parts of the section and may still be preserved there. Source rocks whose generative potential has been destroyed by subsequent tectonic processes (strong deformation and/or metamorphism) are also shown on the maps. In some areas these destroyed source rocks could have contributed at an earlier time to discovered reserves. An example is the deformed middle Cretaceous source rocks 
of the coastal mountains in Venezuela. Before their deformation, these rocks generated hydrocarbons that migrated laterally into the giant heavy-oil accumulations of the Orinoco belt.

\section{CONDITIONS OF DEPOSITION OF MAJOR SOURCE ROCKS}

\section{Silurian (Plate 1)}

The main tectonic events of the Silurian were the closing of the Iapetus Ocean and the collision of the North American and European continents, forming the Caledonian orogen. Passive tectonic regimes prevailed on the opposite sides of the collided continents. An extended seaway, the Proto-Tethyan Ocean, ${ }^{5}$ was first defined at this time; it separated the northern group of continents from the passive northern margin of Gondwana. The subduction of oceanic crust, the widespread formation of volcanic arcs, and the accretion of microcontinents took place along the western Pacific margin, along the Urals, north of the Siberian craton, and around the Kazakh group of microcontinents. The Pacific margin of North America had a passive-margin tectonic regime.

Among structural forms, platforms strongly dominated on the Proto-Tethyan passive margins of the North American, European, and Gondwana continents. Circular and linear sags were common in the continental interiors. The main rifts of Silurian age (initiated already in Ordovician time) were those in the Canadian Arctic, in the Timan-Pechora region of the northeastern Russian craton, on the Taimyr Peninsula, along the Tornquist line in central Europe, and in a chain of basins in central Australia. Foredeeps developed on the American side of the closing Iapetus Ocean.

Marine rocks, as measured from the map, cover 73 percent of the total Silurian depositional area. ${ }^{6}$ The strata were deposited over extensive platforms along the continental margins. Toward the continental interior regions, they pass into mixed marine and continental sections, with the continental rocks being mainly Upper Silurian.

\footnotetext{
The application of the names Proto-, Paleo-, and Neo-Tethys in this study follows the usage of the colloquium on Tethyan mountain chains held during the 26th International Geological Congress (Aubouin and others, 1980).

"Depositional area" in this study designates the area covered by preserved rocks of a particular age. Paleogeographic environments for areas where sedimentary rocks of this age have been truncated were not reconstructed because of the significant uncertainties involved in such reconstructions.
}

Organic-rich graptolitic shales are characteristic source rocks of the Silurian System. Organic matter in these shales is composed primarily of type II kerogen, much of which was derived from planktonic fauna (graptolites, tentaculitids). Later in geologic history, organic matter derived from animals was never as dominant as it was in the Silurian. This unusual genesis of organic matter resulted in a somewhat abnormal composition of kerogen: it is rich in non-hydrocarbon compounds, especially those containing nitrogen, and poor in hydrogen (Bazhenova, 1986). Graptolitic sediments were widely deposited on platforms of the northern margin of Gondwana. They abruptly passed landward into organic-lean sediments of the nearshore facies. Most of the margin is shown on the map to be located in the temperate and subpolar climatic zones at $40^{\circ}-50^{\circ}$ south. In later geologic times, the main depositional areas of type II kerogen were located in significantly lower latitudes. The dominance of animalderived organic matter in graptolitic shales may be responsible for this difference. However, some plate tectonic reconstructions suggest a more northern position of the northwestern Gondwana margin in the Silurian (Smith and others, 1981; Van der Voo, 1988).

The northern group of continents was located mainly in the tropical zone. Around these continents, carbonate sedimentation predominated on shallow-water platforms. Deposition of graptolitic shales was chiefly restricted to deep-water environments, whose distribution was controlled by actively subsiding structures, commonly rifts. Along the Proto-Tethyan margin of these continents and on the Siberian craton, the graptolitic shales were probably deposited on platforms; but many of these areas are now highly deformed, and their Silurian structural profiles are rather uncertain.

Organic-rich Silurian source rocks with highquality type II kerogen cover 42 percent of the total Silurian depositional area. The contribution of petroleum from these source rocks to the world's discovered oil and gas is nevertheless moderate. This relatively low productivity results largely from postdepositional destruction. About two-thirds of the Silurian source rocks have been strongly deformed and metamorphosed due to the splitting of continental slices from the northern Gondwana margin and their accretion onto the Tethyan margin of Eurasia. In addition, sedimentary strata were strongly deformed and partly metamorphosed in most of the Silurian rifts during the Hercynian tectonic event.

Silurian graptolitic shales account for 9 percent of the world's hydrocarbon reserves. Most hydrocarbons generated from Silurian rocks (85 percent) are gas, because of the deep occurrence and overmaturation of the source rocks. All these source rocks were deposited 
in parts of the platforms that have been preserved from destruction south and north of the belt of Tethyan deformations. The main part of the reserves generated by Silurian source rocks is on the platforms of northern Gondwana.

Silurian source rocks are well identified in the Erg Oriental and Erg Occidental basins of north Africa (Tissot, Espitalie, and others, 1984). These basins contain 20 percent of the petroleum reserves generated by Silurian strata. There, oil and gas from Lower Silurian to lowermost Devonian organic-rich graptolitic shales has charged reservoirs in underlying Cambrian and Ordovician strata, in overlying Lower Devonian strata, and in Triassic strata that unconformably overlie the Paleozoic rocks (Balducchi and Pommier, 1970; Magloire, 1970). Although maturation of source rocks began as early as the Paleozoic (especially on the southwest), most preserved petroleum was generated during Cretaceous time.

Although Silurian source rocks are not well studied in the Arabian-Iranian basin, they are the most probable source for gas in carbonate and basal clastic units of the Permian Khuff Formation. The Khuff contains 74 percent of Silurian generated petroleum under a cap rock of Permian and Triassic evaporite. The primary source rocks are dark-brown to black graptolitic shale of the Silurian Gahkum Formation in the Fars province of Iran (Ala and others, 1980) and similar shale of the Silurian Qusaiba Member of the Tabuk Formation in the Tabuk basin south of Jordan (al-Laboun, 1986). In the vicinity of the Qatar-South Fars arch, the Silurian source rocks are apparently absent due to Hercynian uplift and truncation. Paleostructural reconstructions suggest that some migration may have occurred before Permian time. However, the main migration of reservoired gas took place after deposition of the Permian and Triassic evaporite cap rock, at the time when the Silurian source was in the gas window. We speculate that, during Jurassic time, gas migrated into ancient salt-capped traps, which merely served as "way stations." Much later this gas remigrated into fold traps that were formed in Upper Permian rocks of the Zagros belt during Cenozoic time. The gas also filled block-uplift traps on the craton (Northwest Dome, Ghawar, and other structures); the growth of these traps was strongly enhanced by tectonic activation during the same time.

Silurian graptolitic shales deposited on a platform of southern North America contributed small quantities to gas reserves of the Permian and Anadarko basins (Hill, 1971) and to petroleum reserves of the Michigan basin (Gardner and Bray, 1984). Small oil and gas accumulations probably generated by Silurian source rocks are known in southeastern Turkey and in the Timan-Pechora basin of the U.S.S.R. (Vasserman and others, 1977). However, source rocks in the latter may be of Ordovician age.

\section{Upper Devonian-Tournaisian (Plate 2)}

Collision of the Euroamerican continent with northern Africa in the Late Devonian closed the central segment of the Proto-Tethyan Ocean. The resulting Acadian and Variscan deformations, volcanism, and accumulation of thick molasse deposits continued well into Carboniferous time. North of the collision zone, continuous adjustment along the older Caledonian belt, beginning in the Early Devonian, resulted in widespread rifting of the Old Red continent. East and west of the collision zone, the remaining parts of the Proto-Tethys were bounded by passive margins on the south and active subducting margins on the north. The circumpacific accretion zone first formed in the Devonian and persisted through the remainder of geologic history. Deformation along this zone, widespread continental and oceanic arc volcanism, and repeated accretion of microcontinental blocks and other alien terranes became prominent features of Pacific margins at this time. The clockwise rotation of Siberia and the northwestern drift of the already accreted Kazakh continent resulted in gradual narrowing of the Uralian and Irtysh-Zaysan (Ob-Zaysan) oceans. Other microcontinents (like, for example, South Kara) that are now deeply buried under younger rocks of the West Siberian basin could have existed in this region. Rifting and splitting of northern and southern China and the Scythian-Turanian microcontinent (or a group of continental blocks) from northeastern Gondwana initiated opening of the Paleo-Tethyan Ocean.

Structural forms that controlled Late DevonianTournaisian deposition are diverse. Platforms and gentle circular sags were common in inner parts of continents and on forelands landward of the active margins. Half sags developed along the southern margin of the opening Paleo-Tethys. Foredeeps formed in the back of continental magmatic arcs along the Pacific margin, in the Hercynian collision zone, and on the Canadian Arctic Archipelago. Rifts, some of them accompanied by basic volcanism, were widespread in the northern group of continents.

Marine rocks formed over approximately half of the depositional area of Late Devonian-Tournaisian time. One third of this area was overlain by rocks of mixed marine and continental origin, with continental rocks more common in the upper parts of sections than in the lower parts. Wholly terrestrial rocks are restricted to 14 percent of the depositional area and consist chiefly of alluvial units formed along the shorelines of epicontinental seas and in rifts of the Old Red continent. 
Source rocks of Late Devonian-Tournaisian age consist largely of organic-rich siliceous shale, marl, and limestone with dominant type II kerogen. This association of rocks is often called the black-shale facies. During Late Devonian-Tournaisian time, this facies was mainly deposited on platforms and in cratonic circular sags in the course of a widespread marine transgression. In contrast to the unusual high-latitude origin of Silurian source rocks, structural platforms of this interval were located in the tropical and temperate zones $\left(0^{\circ}-45^{\circ}\right.$ latitude). They occupied extensive forelands landward of active tectonic margins. Source rocks covered 21 percent of the entire Upper Devonian-Tournaisian depositional area. Areally, approximately 70 percent of the source rocks were preserved, but 30 percent have been destroyed by metamorphic processes.

Eight percent of the world's original petroleum reserves were generated by Upper Devonian-Tournaisian source rocks; 80 percent of the reserves generated from the interval are oil. Basins of the eastern margin of the Russian craton (Volga-Ural, Timan-Pechora, North Caspian) contain much of the petroleum of this interval. The principal source rock for these basins is the Domanik Formation, which is composed of organic-rich (organic carbon to 20 percent), marine, black, siliceous shale and limestone with type II kerogen (Zhuze and others, 1975; Ashirov and others, 1981; Ulmishek, 1982). Although migration of immature oil may have started in the Carboniferous (Ulmishek, 1988), the main maturation stage and the main migration accompanied the deposition of Hercynian molasses (Upper PermianTriassic). The oil was expelled into both underlying Middle Devonian and overlying Carboniferous and Lower Permian rocks as well as into adjacent reefs. Oil dominates in the reserves of petroleum of the TimanPechora and Volga-Ural basins. Giant gas-condensate accumulations of the North Caspian basin are sealed by the Kungurian salt cap.

Organic-rich, dominantly sapropelic (type II kerogen), bituminous black shales of the North American craton are rather similar to the Domanik source-rock facies of the eastern Russian craton. At least two-thirds of original petroleum reserves in Alberta are derived from these Upper Devonian and Lower Mississippian source rocks (Duvernay, Ireton, Exshaw, and Bakken Formations) (Parsons, 1973; Porter and others, 1982).

\footnotetext{
${ }^{7}$ Large gas-condensate and oil reserves of the North Caspian basin have been generated by a condensed black-shale section of Late Devonian through Early Permian age. In this paper, we assign one-half of these reserves to the Upper Devonian-Tournaisian interval and those remaining to the Pennsylvanian-Lower Permian interval.
}

Although some maturation and migration of hydrocarbons may have occurred in the Jurassic, most migration commenced with the formation of the Cretaceous foredeep.

Organic-rich black shales are widespread in the basins on the southeastern margin of the North American craton. They are present among deltaic and prodeltaic facies of the Chemung Formation and among prodeltaic and platform marine facies of the Chattanooga Shale in the Appalachian basin. They also compose the platform marine Woodford Shale in the Greater Anadarko and Greater Permian basins. These black shales are the principal source rock of the Appalachian basin and are the secondary sources in the Anadarko and Permian basins (Landes, 1970; Hill, 1971; Ray, 1971). Maturation of these shales probably commenced in late Paleozoic time.

In some of the craton interior basins of North America, South America, and northern Africa, Upper Devonian-Tournaisian black shales deposited in circular sags are proved to be the major source rocks (North, 1985). These include the bituminous New Albany Shale of the Illinois basin (Barrows and Cluff, 1984), the Bakken Formation shale of the Williston basin (Meissner, 1984), and the Antrim Shale of the Michigan basin. Somewhat less organic-rich shales of this age are known in the Barreirinha Member of the Curua Formation in the Amazon basin (Mosmann and others, 1986) and in the Upper Devonian section of the Illizi subbasin of the Erg Oriental basin in north Africa (Tissot, Espitalie, and others, 1984; Aliyev and others, 1979).

The time of maturation and migration of hydrocarbons from Upper Devonian source rocks of the Michigan and Illinois basins is uncertain. These black shales at their present depth are at maturation levels that indicate either that they were once buried 3,000 to 5,000 feet deeper than their present depth, or that a regional thermal event produced geothermal gradients significantly higher than those of today. The most probable time intervals of maturation and migration are Late Cretaceous and Early Tertiary in the Williston basin, Late Permian to Jurassic in the Amazon basin, and Permian to Late Cretaceous in the basins of north Africa.

Organic-rich Upper Devonian and lowermost Carboniferous rocks deposited in a rift are the main source for petroleum in the Pripyat and Dnieper-Donets basins of the Russian craton. In the Pripyat basin, wellstudied Upper Devonian source rocks are black shales and limestones with the average organic carbon content of 2 percent (Chaykovskaya and Volik, 1986). Tournaisian shale and carbonate rocks with organic carbon contents of 0.7-3 percent are probably the main source for hydrocarbons in the Dnieper-Donets basin (Il'inskaya 
and Kulayeva, 1979), although Upper Devonian and younger Carboniferous rocks may have generated some oil and especially gas (Vitenko and others, 1985).

\section{Pennsylvanian-Lower Permian (Plate 3)}

The collision of western Gondwana with North America and Europe continued into the Pennsylvanian-Early Permian and resulted in the Hercynian orogeny, during which the Mauritanian, Ouachita-Marathon, Alleghenian, and Variscan fold belts formed, strike-slip faulting was widespread, and orogenic molasses were deposited in foredeeps and intermontane depressions. Another series of major tectonic events took place to the east. Collision of the Kazakh and Siberian continents with the eastern margin of the Russian craton resulted in formation of the short-lived Laurasian supercontinent. The collision was accompanied by volcanism on continental margins and intense deformation in the Uralian and Irtysh-Zaysan fold belts. Subduction under the southeastern margin of Laurasia closed the ProtoTethyan Ocean, as the North China continent (including the Tarim block) and a number of microcontinents docked with Laurasia. These microcontinents are now incorporated into the Alpine fold belts and the accreted zones north of them. The eastern arm of a new Tethys (the Paleo-Tethyan Ocean), surrounded by passive continental margins, was now opened south of the collision zone. An outer subduction zone existed offshore from the North American Pacific margin, but the continental edge, along the marginal seas between this zone and the continent, had a passive tectonic regime. Rifting, commonly associated with strike-slip movements, was fairly active on all continents, especially in southern North America.

The Pennsylvanian-Lower Permian depositional area is nearly equally divided into three parts covered by marine, continental, and mixed facies. Marine sedimentation characterized the Arctic passive margin of Laurasia and the passive margins of Paleo-Tethys. Continental facies covered large areas in the polar and glaciated subpolar zones landward from the continental margins. Mixed facies including abundant paralic rocks predominated on active margins and in the zones of the Hercynian deformation (except for the Urals, where terrestrial sedimentation commenced in Late Permian time).

Structural platforms of Pennsylvanian-Early Permian time occupied the large areas on continents and along the passive margins of Gondwana and northern Laurasia. Rifting was active during Permian time, especially in zones along which the Neo-Tethys was later opened and the breakup of Gondwana occurred. Foredeeps were most abundant in the belts of the Hercynian orogeny. A series of wrench rifts, transverse to the collision suture, is found in southern North America; such rifts are less common along other active margins.

The character and distribution of PennsylvanianLower Permian source rocks differ significantly from those in the older Paleozoic stratigraphic intervals. For the first time, sedimentary rocks with type III kerogen and especially coals became an important source of hydrocarbons. These deposits cover more than one-half of the area that contains source rocks in the Pennsylvanian-Lower Permian section and are responsible for more than 20 percent of the hydrocarbons generated by this section. Rifts and foredeeps were the major structural forms that controlled source-rock deposition, and platforms were much less important than they had been previously. The great accumulations of orogenic molasses, the deep burial of source rocks, and the coaly nature of organic matter in a number of basins resulted in a predominance of gas over oil. Almost two-thirds of discovered hydrocarbons that have been generated by the Pennsylvanian-Lower Permian section are gas. Another reason for the dominance of gas in reserves is probably the exceptionally wide distribution of evaporites among Permian rocks (fig. 3). The evaporites constitute perfect cap rocks that seal 60 percent of generated hydrocarbons and prevent the escape of gas.

In high latitudes, where evaporite seals are absent, gas derived from the widespread coal deposits (fig. 3) could form only local accumulations retained by shale caps in especially favorable conditions, as for example, in the Vilyuy basin.

Pennsylvanian-Lower Permian source rocks have generated 8 percent of the world's discovered hydrocarbon reserves. More than half of the reserves are concentrated in the greater Anadarko and greater Permian basins ${ }^{8}$ of the south-central United States. We estimate that about 75 percent of hydrocarbons discovered in these two basins have been generated by Pennsylvanian, Lower Permian, and lowermost Upper Permian rocks. Much of the oil and gas migrated into dominantly salt-capped carbonate and clastic reservoirs of Late Permian age (Adler, 1971; Hartman and Woodard, 1971). These sapropelic source rocks with dominant type II kerogen were deposited in a combined structure consisting of a foredeep on the southeastern basin margin and a rift/sag duplex over older platform sequences on the basin's northwestern cratonic margin. Maturation and migration of oil and gas began during Late Permian-Triassic time.

\footnotetext{
${ }^{8}$ Source rocks in the lower part of the Upper Permian section of the Permian basin are included in calculations because their contribution to the hydrocarbon reserves (probably relatively small) cannot be separated from that of the underlying rocks.
} 


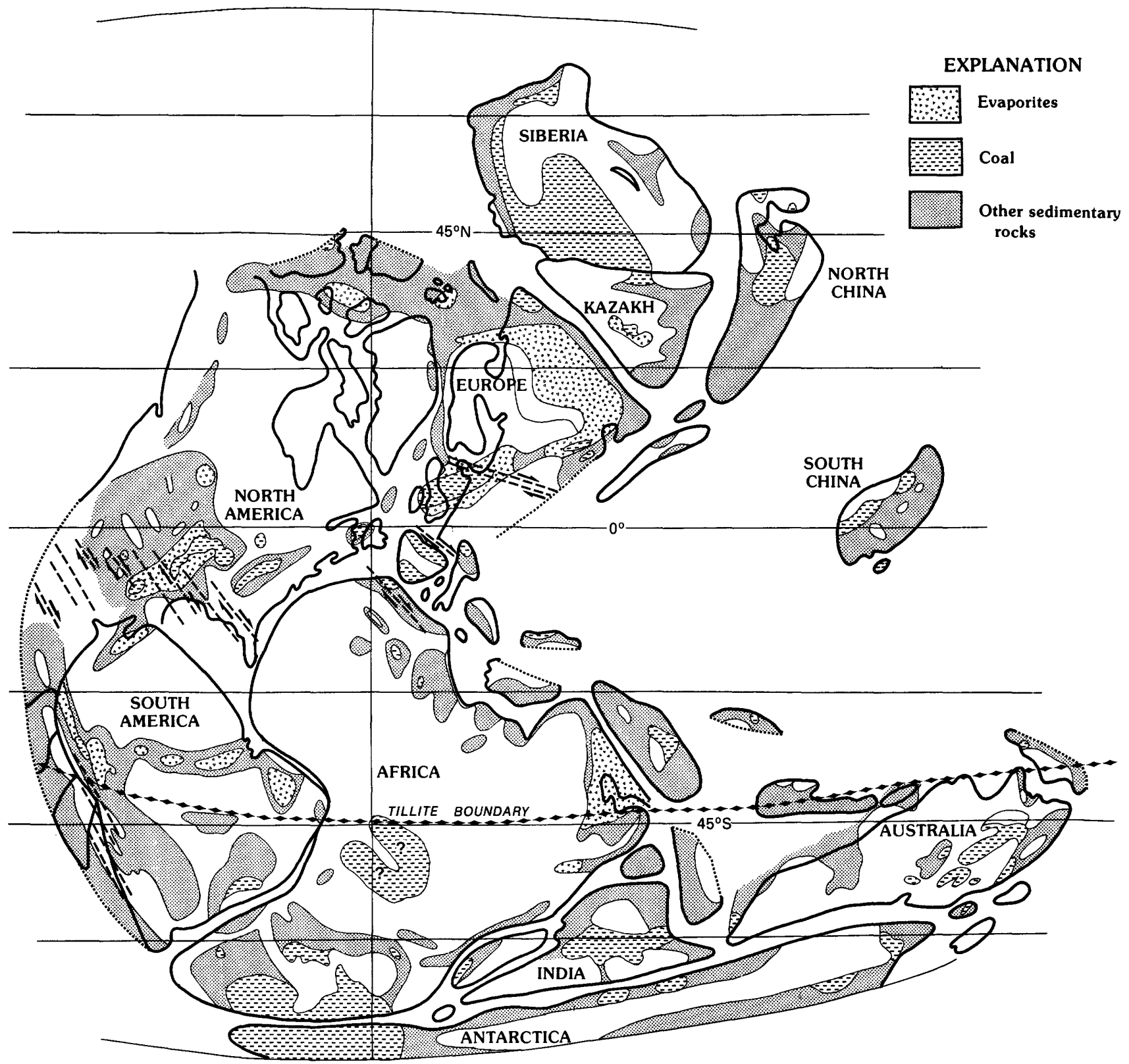

Figure 3. Distribution of evaporites and coals in the Pennsylvanian-Lower Permian stratigraphic interval.

Almost one-fifth of hydrocarbon reserves generated by the Pennsylvanian-Lower Permian-stratigraphic interval are concentrated in the southern North Sea subbasin, and these predominantly consist of dry gas. The gas has been generated by the thick Westphalian (middle Upper Carboniferous) coal measure deposited in the Hercynian (Variscan) foredeep (Ziegler, 1980); it is reservoired in Lower Permian sandstones under the Zechstein salt cap. Maturation and migration began in the early Mesozoic and continued into the Tertiary. Overmaturation of coals occurring now at depths as great as 5-6 miles has resulted in a high content of nitrogen in many gas fields. Small reserves of gas condensate and oil have been generated by the Kupferschiefer and Stinkschiefer black shales with type II kerogen and are reservoired in Zechstein carbonates.

Large gas condensate and oil reserves of the North Caspian basin probably have been generated by deepwater basinal facies of Late Devonian through Early Permian age deposited in a circular sag. Middle Carboniferous to Lower Permian black shales and marls are not well studied by geochemical methods because 
they are deeply buried. However, these rocks average 1-2 percent organic carbon in marginal sections and as much as 6 percent in sections more remote from provenance areas (Fomkin, 1985). Hydrocarbon accumulations occur in reefs and carbonate banks overlain by thick Kungurian salt. The main stage of maturation and migration took place during Late Permian-Triassic time, when thick, primarily continental clastic sediments were deposited over the salt formation. The basin is still poorly explored, and its share of the reserves generated by Pennsylvanian-Lower Permian rocks may be expected to substantially increase in the future.

The Lower Permian Phosphoria Formation has been the source of about $\mathbf{4 0}$ percent of the hydrocarbons found in the Rocky Mountain basins of northern Utah, northwestern Colorado, Wyoming, and south-central Montana. There, phosphatic shale members of the Phosphoria, enriched by type II kerogen, were deposited on the eastern flank of a linear sag on a platform margin that gradually rose eastward into western Wyoming and Montana and eastern Idaho (Stauffer, 1971; Cannon, 1971; Peterson and Smith, 1986). It is believed that maturation of these source rocks and migration of hydrocarbons commenced with Cretaceous burial about $125 \mathrm{Ma}$ and ceased before the Laramide orogeny at 65 Ma (Claypool and others, 1978). Owing to continuity of carrier beds, petroleum could migrate laterally over a distance of some 240 miles into eastern Wyoming reservoirs.

Permian continental clastic rocks that include coal beds are the main proved source rocks for large gas fields found within these same rocks and in younger rocks of the Vilyuy basin of East Siberia (Cherskiy, 1986). The rocks were deposited in a structural sag developed over a Devonian rift. The east side of the sag was opened to the continental slope prior to the Late Jurassic-Early Cretaceous Verkhoyansk orogeny. Maturation and migration of petroleum in the eastern part of the basin may have begun as early as the Triassic. However, the main generation of gas was in Jurassic to Early Cretaceous time (Cherskiy, 1986).

The Lower Permian Yangxin black and gray argillaceous micritic limestones are the main source of gas in the Sichuan basin of southern China (Huang, 1984). The limestones were deposited over a relatively deep but open platformal shelf during a widespread marine transgression (Wang and others, $1983 ; \mathrm{Li}$ and $\mathrm{Li}$ [1984]). The gas is contained mainly in Permian and Lower Triassic reservoirs. The early maturation and migration probably took place during Jurassic and Cretaceous time. The source rocks reached a stage of overmaturity, and much of the oil was transformed into gas after the Late Cretaceous Yanshanian orogeny in the adjacent Longmenshan Mountains and the resulting deposition of thick molasses.
Judging from recent geochemical studies, the Upper Carboniferous marine black-shale facies was the principal source for oil in the Karamay field of the Junggar basin of western China (Lin, 1984). A recent oil discovery in the northeastern part of the basin probably had the same source.

Permian coal is a source for gas, gas condensate, and small amounts of oil in fields of the Permian through Lower Cretaceous section of the Cooper subbasin of the Great Artesian basin of Australia. The coal-bearing sequence formed in a rift and reached maturity during, or soon after, the deposition of the thick Cenomanian section. In the deep Nappamerri trough, however, the coal beds matured earlier, in Early Cretaceous time (Kantsler and others, 1984).

\section{Upper Jurassic (Plate 4)}

The microcontinents that split off from northern Gondwana gradually closed the Paleo-Tethys in front of them as they drifted northward. The Neo-Tethyan Ocean was opened between the microcontinents and the passive margin of Gondwana. Volcanic rocks were common in both continental and oceanic arcs along the northern active margin of the closing Paleo-Tethys. Passive continental margins formed along both sides of the opening Neo-Tethys. The southeastern movement of Africa relative to North America resulted in the opening of the western arm of the Neo-Tethys. The two parts of the ocean were connected via relatively narrow basins underlain by oceanic crust (Ligurian and Vardar oceans). Later, the western part of the Neo-Tethys was incorporated into the spreading system of the Atlantic. Rifting in Gondwana resulted in opening of the oceanic crust between Africa on one side and India and Madagascar on the other. All of the circumpacific margin had an active tectonic regime, which included volcanism and the accretion of microcontinents, both especially pronounced along the western margins of both Americas.

Triassic and Jurassic time is characterized by widespread rifting commonly associated with basic volcanism. In many regions, rifting continued into the Late Jurassic. In other areas (such as western Siberia and the North Sea), rifting was terminated earlier and linear and circular sags formed over the rifts during Late Jurassic time. The main rift systems developed in zones of weakness along which, in later geologic times, the breakup of Gondwana and the separation of North America and Eurasia took place. Several rift troughs formed east of the continental magmatic arcs of South America; these rifts now underlie Cenozoic foredeeps.

An extensive Late Jurassic marine transgression, which reached its culmination in the Oxfordian and Kimmeridgian, resulted in the abundance of marine 
rocks. Marine rocks cover 61 percent of the Upper Jurassic depositional area. They were largely formed along Tethyan continental margins, in Arctic regions, and in extensive epicontinental basins of Europe and western Asia. Continental rocks covered 22 percent of the depositional area. They formed in intracontinental basins of a variety of tectonic types and they are especially characteristic of basins in China. Remaining depositional areas contain mixed marine and continental rocks; the latter are most common in lower and upper parts of the Upper Jurassic section.

The distribution of Late Jurassic structural forms reflects the regional tectonic regimes. Rifts and especially linear and circular sags that developed over Triassic and earlier Jurassic rifts are very characteristic. Half sags surrounded the opening Neo-Tethys. Platforms are not common, but are present in the interiors of inundated cratons. Foredeeps are rather unusual for this interval, which had no significant orogenies; they are chiefly restricted to basins in eastern Asia and western Canada.

Source rocks with type II kerogen are characteristic of the Upper Jurassic; they are present over three-quarters of the area that contains source rocks of this interval, and they extend much farther from the equatorial climatic zone into subpolar and polar latitudes than they had in either of the upper Paleozoic intervals discussed above. The confinement of the source rocks to certain structural forms also contrasts with that of older intervals. The majority of the rocks were deposited in relatively deep, silled marine basins in large linear and circular sags. Source rocks that contain type III kerogen and coal are not abundant in the interval. They are chiefly restricted to high paleolatitudes and are nearly absent from the tropical and temperate zones. Their absence in low paleolatitudes is probably due to the arid climatic conditions of the time indicated by the abundance of evaporites and red beds in the Alpine fold belts, the Middle East, the southern Rocky Mountains, and many other localities.

Upper Jurassic source rocks cover 27 percent of the area of deposition; most (90 percent) have not been destroyed by subsequent metamorphism. These source rocks were highly effective; they have generated 25 percent of the original petroleum reserves of the world, and 74 percent of the petroleum they have generated is oil. The largest share of petroleum reserves from this interval (46 percent) is located in the Arabian-Iranian basin. Upper Jurassic source rocks of the basin include the lower Kimmeridgian Hanifa and Diyal/Dukhan sapropelic bituminous marls and Bathonian to Oxfordian bituminous black shale and limestone of the Sargelu Formation (Ayres and others, 1982; Klemme, 1984; Alsharhan, 1987; Alsharhan and Kendall, 1986). These source rocks were deposited in the Basrah-Lurestan and Dezful basins, both separated from the ocean by the
Surmeh carbonate platform (Koop and Stoneley, 1982). These structures, described as "intrashelf basins" and "deeper shelf" by Murris (1980), are classified here as linear sags. Oil that was generated by the source rocks is contained in Upper Jurassic calcarenitic and oolitic Arab Zone reservoir rocks and middle Cretaceous rudistid and algal reefs and mounds of the Shuaiba Formation. Maturation of the source rocks and migration of the petroleum involved two phases: (1) early to middle Cretaceous long-distance lateral migration from the Sargelu source rocks to the Arab Zone, and (2) vertical migration from the Hanifa and Diyal/Dukhan source rocks to the Arab Zone and the Shuaiba Formation after the initial Late Cretaceous collision of Arabia with Asia. That collision resulted in the deposition of molasse and the deep burial and maturation of the source rocks. In this area, an ideal juxtaposition of prolific source rocks, excellent reservoir rocks, and good seals (Hith evaporite for the Arab Zone and Nahr Urm shales and marls for the Shuaiba Formation) resulted in the generation and preservation of giant oil reserves.

Highly organic-rich (organic carbon content more than 10 percent), black siliceous shale of the Bazhenov Formation of Volgian age is the main petroleum source for the very large oil reserves of the central West Siberian basin (Stasova, 1977; Ivantsova, 1969) and possibly for a part of the gas reserves in the northern areas of the basin (Grace and Hart, 1986). Oil occurs mostly in the Neocomian deltaic reservoirs that overlie source rocks in the Middle $\mathrm{Ob}$ region. Bituminous Bazhenov shale that contains type II kerogen was deposited in a deep-water silled basin in a large circular sag that formed over an extensive Triassic rift system (Kulikov, 1979). The main stage of maturation of source rocks occurred during deposition of the thick Upper Cretaceous-lower Tertiary section (Kontorovich and others, 1975).

Organic-rich, sapropelic black shale of Late Jurassic (Kimmeridgian) age in the North Sea (Viking graben, Central graben, and Trondelag platform) is a stratigraphic and facies analog to the Bazhenov shale of West Siberia. The Kimmeridgian shale was deposited in a linear sag overlying the Triassic to Middle Jurassic rift sequence. Major hydrocarbon reserves are found in Middle Jurassic deltaic sandstones of the rift and in uppermost Cretaceous-lower Tertiary chalk and sandstone (Ziegler, 1980; Cooper and Barnard, 1984). Peak petroleum generation occurred in the early Tertiary (Goff, 1984; Baird, 1986). Migration of oil and gas has continued to the present, probably in pulses from compartments with abnormally high fluid pressure in the source shale (Hunt, 1988).

In the Gulf Coast, Reforma-Campeche, and Tampico-Chicontepec provinces around the Gulf of Mexico, Kimmeridgian-Tithonian organic-rich shale containing dominant type II kerogen was deposited in a 
circular sag above extensive salt deposits of Callovian age (Louann and Isthmian Formations), which in turn were underlain by Triassic rifts (Salvador and Green, 1980; Peterson, 1983, 1985; Salvador, 1987). The shale achieved maturation in middle Cretaceous time in the Gulf Coast province and in the late Tertiary in the other two provinces. In the Gulf Coast, the petroleum migrated updip, into Upper Jurassic carbonate and Upper Jurassic and Lower Cretaceous clastic reservoirs. In the Reforma-Campeche province, reservoir rocks are Cretaceous rudistid carbonate rocks, Paleocene carbonate breccia, and possibly Miocene sandstones. Salt tectonics played an important role in formation of traps. The petroleum migrated into Cretaceous rudistid reefs and reef talus in the Tampico area and into Eocene sandstones in the Chicontepec area.

Upper Oxfordian-Kimmeridgian black bituminous shale and limestone of the Khodzhaipak Formation underlying thick Kimmeridgian-Tithonian salt is the major source for gas, gas condensate, and oil in fields in the Amu-Darya basin in Soviet Central Asia (Akramkhodzhayev and Egamberdyev, 1985). These deep-water facies rocks were deposited in a linear sag over the Triassic (or Permian) through Early Jurassic rift system (Maksimov and others, 1986). Petroleum migrated into Upper Jurassic reefs capped by salt and into Neocomian and Aptian sandstones in areas where the salt cap pinches out (Krylov, 1979; Semashev, 1983). The main stage of maturation was achieved in late Tertiary time during deposition of the Alpine molasse (Seregin and others, 1982), although rocks in the deepest parts of the basin could have matured earlier. Other basins in foredeeps of the Alpine fold belt of the southern U.S.S.R. also have deep-water Oxfordian and Kimmeridgian shale and carbonate rocks beneath Tithonian salt deposits. In most areas these rocks are poorly known because of their very deep occurrence. Probably, they are the major source for large reserves of oil in the Mesozoic section of the Groznyi area north of the eastern Caucasus, one of the sources for the East Kuban depression north of the central Caucasus (Chakhmakhchev and others, 1987), and one of the sources for the AfghanTadzhik basin (Safranov and others, 1983).

Significantly smaller petroleum reserves generated by Upper Jurassic source rocks are known in the Neuquen and San Jorge basins of Argentina, the Great Artesian basin and Northwest Shelf of Australia, offshore northeastern North America, Morocco, and the North Slope of Alaska. In the latter region, the amount of petroleum from the Upper Jurassic source cannot be separated from the amount generated by Triassic and older Jurassic rocks. Presumably, the Upper Jurassic contribution is relatively small because of truncation of these rocks toward the major petroleum accumulations. Recent data indicate that Upper Jurassic basinal marl characterized by type II kerogen is the main source for petroleum produced in the Vienna basin (Ladwein, 1988). Maturation was achieved after the Late Cretaceous-Paleogene overthrusting during deposition of the Neogene molasse.

\section{Middle Cretaceous (Plate 5)}

The Paleo-Tethyan Ocean was finally closed during Neocomian time, although continental volcanism along the suture continued well into the middle Cretaceous. The subduction zone and associated magmatic arcs along the southern margin of Eurasia shifted to the southern, previously passive margins of the accreted microcontinents. The breakup of Gondwana had already begun in the Late Jurassic and Neocomian, as can be seen from the occurrence of oceanic crust of this age between southern Africa and Antarctica. Areas of Upper Jurassic-Neocomian oceanic crust are also known in the western arm of the Neo-Tethys, in the Gulf of Mexico, and in the southeastern Mediterranean. Formation of the oceanic crust in the Black and Caspian Seas probably also began during this time.

The breakup of the Gondwana continent progressed substantially during the middle Cretaceous. The South Atlantic began to open in Aptian or early Albian time. The Indian subcontinent separated from Gondwana in the Late Jurassic and began its fast drift northward, narrowing the eastern Neo-Tethys and opening the Indian Ocean at its trailing margin. The breakup resulted in formation of extensive new passive margins on the edges of the separated continental blocks. Rifting occurred between Antarctica and Australia and between North America and Europe preceding the Late Cretaceous-early Tertiary separation of these continents. The North Slope of Alaska collided with the accreted terrane to its south, thereby completing the opening of the Canada basin in the Arctic. The circumpacific subduction zone continued to operate, resulting in the accretion of a number of terranes and in volcanism on the active margins, which was most intense in northeastern Asia.

Middle Cretaceous sedimentation occurred during a gradually proceeding marine transgression that reached its maximum in Turonian time. The transgression covered all the passive continental margins and penetrated far into most continents. Marine and mixed marine and continental facies were dominant; continental sediments were deposited only in the isolated intracontinental depressions in South America, Africa, and eastern Asia.

Structural forms of the middle Cretaceous interval are diverse. Linear and circular sags continued to develop over Late Jurassic sags and over some of the 
Late Jurassic rifts. Half sags were formed along the passive margins of the separated continents of Gondwana. Platforms developed chiefly in the internal parts of continents covered by epicontinental seas. Foredeeps formed in many of the Chinese basins (a result of the thrust faulting of the Yanshanian orogeny), in the northern Rocky Mountains, and along the north margin of the Brooks Range in Alaska. Rifts were not abundant in the middle Cretaceous, although some of them are known on the margins of the North Atlantic, in southern South America, and in southern Australia.

Potential source rocks of middle Cretaceous age are present in 27 percent of the depositional area. The character of these rocks differs significantly from those of the Upper Jurassic stratigraphic interval. Source rocks with types I or II kerogen are less abundant than those that contain kerogen type III. In high latitudes type III kerogen and coal are much more common than they were in the Upper Jurassic; type I kerogen was deposited locally in lakes. Rocks containing marine type II kerogen are almost exclusively confined to the Tethyan seaway. They were deposited mainly as relatively deep-water basinal facies in silled linear and circular sags. Source rocks with continentally derived type III kerogen and coal are found mostly in half sags and linear sags that formed along the newly created passive continental margins, in foredeeps, in some gentle sags, and over interior platforms. Effective middle Cretaceous source rocks are characterized by all three types of kerogen; most were deposited in linear and circular sags.

A large share of the world's oil and gas reserves (29 percent) has been generated by source rocks of middle Cretaceous age. Significantly, despite the widespread occurrence of type III kerogen and coal, the contribution of this kerogen type to discovered reserves is only moderate. The only place it has made a major contribution is in the giant reserves of dry gas in the Cenomanian reservoirs of northern West Siberia, beneath the Turonian shale cap reinforced by permafrost. This gas very likely originated biogenically from coaly organic matter of the Albian-Cenomanian Pokur Formation (Nesterov and others, 1978; Rice and Claypool, 1981). Its mechanism of accumulation was unique: gas from formational water repeatedly froze into hydrates during glacial epochs, and then was liberated by melting during interglacial stages (Kortsenshteyn, 1970). This mechanism effectively extracted gas dissolved in underground water. Some input of thermogenic gas from deeply buried Jurassic(?) rocks is possible (Grace and Hart, 1986), but probably was not important.

More than half of petroleum reserves generated by middle Cretaceous rocks are located in the ArabianIranian basin. The petroleum is concentrated in two main areas. Giant oil and gas reserves are present in Oligocene-Miocene reservoirs in an area 200 miles long and 60 miles wide in frontal ranges of the Zagros Mountains (Hull and Warman, 1970; James and Wynd, 1965). The main reservoir is fractured Asmari limestone, which is productive under the Gach Saran (Fars) salt and anhydrite seal in the foredeep folds formed by collision along the Neo-Tethyan suture. The middle Cretaceous Kazhdumi Formation-an ammonite-bearing, organicrich shale and a subordinate argillaceous limestone deposited in a linear sag-is the source for Asmari oil and gas (Dunnington, 1958; Ala and others, 1980). It seems probable that the initial vertical migration of hydrocarbons from the Kazhdumi Formation was into Upper Cretaceous carbonate units ("way stations") and that the oil and gas later remigrated into Asmari limestones, after folding and fracturing (Young and others, 1977; Ala, 1982). Detailed analyses of the regional relations of these source, reservoir, and cap rocks are provided by Murris (1980) and Koop and Stoneley (1982).

The Burgan delta is another area of the ArabianIranian basin where a giant hydrocarbon accumulation was generated by middle Cretaceous source rocks. The productive reservoirs are eastward-prograding deltaic sandstones of early middle Cretaceous age (Dunnington, 1967; Ala and others, 1980). Maturation of middle Cretaceous source rocks in the deepest parts of the basin and migration of petroleum commenced in latest Cretaceous time, but most source rocks reached maturity only in middle to late Tertiary time.

Most oil in the Maracaibo basin of Venezuela is proved to have been generated from organic-rich (type II kerogen) shale and limestone of the middle Cretaceous La Luna Formation (Zambrano and others, 1972; Blaser and White, 1984). The rocks were formed in an anoxic environment in a linear sag near the continental edge. Maturation of the organic matter began as early as the Eocene in the northeastern part of the basin and continues to the present. However, the main maturation/ migration stage occurred during late Miocene and Pliocene time (Blaser and White, 1984). The La Luna stratigraphic and facies equivalent (Querecual Formation) covers the northern part of the East Venezuela basin (Hedberg, 1950). This source rock was responsible for the formation of the Orinoco heavy oil belt. It also supplied oil to the recently discovered El Furrial giant (or supergiant?) oil field and to other large fields discovered in front of the northern thrust belt (Krause, 1988). Maturation of the source rock and migration of oil started in the Paleocene and continued to the present. Further rapid growth of discovered oil reserves in this region, which is highly probable, would significantly change the distribution of petroleum reserves generated by middle Cretaceous source rocks. Geochemical data 
indicate that the La Luna shale and marl have also generated oil found in the Middle Magdalena basin (Zumberge, 1984).

In the Alberta basin, a synorogenic clastic wedge of the foredeep contains large petroleum reserves in Lower and Upper Cretaceous sandstone reservoirs. The source rock for this petroleum is middle Cretaceous marine shale, which mostly contains type III kerogen (Parsons, 1973). This shale may also have been the source of the oil that created the Athabasca tar sands, though this point is still under debate (Moshier and Waples, 1985); other likely sources are Triassic and Upper Jurassic rocks (which were destroyed during the Laramide orogeny) and Upper Devonian rocks.

Several other hydrocarbon-producing regions in the world with smaller but substantial reserves were fully or partly dependent on middle Cretaceous source rocks. In the Gulf Coast basin, marine shale (type II kerogen) deposited in a circular sag contributed significantly to Cretaceous carbonate and sandstone reservoirs (Rainwater, 1971; Holcomb, 1971). Middle Cretaceous rocks, commonly Aptian-Albian marine shale (dominant type II kerogen), probably generated oil and gas in basins of the northern Caucasus (Arkhipov and others, 1979; Mirzoyev and Dzhaparidze, 1979) and Crimea (Shestopal, 1979), and also may have contributed in the Amu-Darya basin in Soviet Central Asia (Maksimov and others, 1987), although the connection of petroleum reserves with these source rocks is not well proved by geochemical data. Aptian euxinic marine shales (mixed types II and III kerogen) are widespread in the southern Atlantic (Tissot, Demaison, and others, 1984). The shales, however, are not responsible for petroleum reserves in rifted marginal basins of the Atlantic. Oil and gas in these basins were generated from upper Neocomian-Aptian lacustrine shales in rift sections and from Aptian basal marine shales in sags developed over the rifts. The basal black shales were formed before the opening of the ocean. Both types of source rocks generated petroleum in basins of the continental margin of Brazil (Ponte and others, 1980). In basins of offshore west-central Africa, source rocks are also present among Neocomian lacustrine shales (Clifford, 1986); however, the main source rock is probably the lower Aptian euxinic black shale phase that directly underlies the Aptian salt section (Lehner and De Ruiter, 1977). This shale is absent over many basement highs, but it is developed in depressions, especially in the northern basins.

Petroleum reserves on the Alaskan North Slope are thought to have been generated from several Triassic to middle Cretaceous source-rock units (Carman and Hardwick, 1983). The contributions of the individual source-rock units are difficult to differentiate, so the quantities assigned to various intervals should be considered speculative. The shale of the middle to upper
Cretaceous "high radioactive zone" (organic carbon up to 12 percent) in the area of the Kuparuk field and the Hue Shale of northeastern Alaska described by Molenaar and others (1987) both contain mixed types II and III kerogen (type III being more abundant). Where mature, the Hue Shale is a good source rock for both oil and gas (Bird and Magoon, 1987).

The Songliao basin in China is the largest petroleum province that depends on nonmarine source rocks (type I kerogen). Black shale (organic carbon as high as 8-10 percent) of the middle Cretaceous Qingshankou and Nenjiang Formations gave rise to giant oil accumulations in a large delta that filled the lake basin (Yang and others, 1985). The shale was deposited in a deep-lake environment in a linear sag that was formed over the Jurassic-Early Cretaceous rift system (Zhou and others, 1985). Peak generation and migration of oil coincided with the growth of main structures during latest Cretaceous-early Tertiary time (Yang, 1985).

\section{Oligocene-Miocene (Plate 6)}

Collision of the Indian subcontinent and the Arabian Peninsula with southern Asia led to the closing of the eastern Neo-Tethys and orogeny. The last remnant of the Neo-Tethys was restricted to the eastern Mediterranean, where the oceanic crust was being subducted under the Aegean volcanic arc. Rifting in the Red Sea separated Africa from the Eurasian continent. Passive margins surrounded the newly formed Indian Ocean, except for the northeastern edge, where subduction of the Indian plate resulted in volcanism and deformation in Southeast Asia.

The Atlantic Ocean, bounded by passive margins, absorbed the western Neo-Tethys. Spreading along the mid-Atlantic Ridge progressed into the Arctic Ocean with formation of the Gakkel Ridge. Simultaneously, spreading in the Canada basin ceased. At this same time, the separation of South America from the Antarctic Peninsula opened the circumantarctic seaway and led to the glaciation in Antarctica. Subduction of oceanic crust under much of the eastern Pacific margin resulted in volcanism, orogeny, and formation of foredeeps landward of volcanic arcs. In the western Pacific, Cretaceous subduction and continental volcanism gave way to Tertiary rifting and the formation of marginal seas.

General late Tertiary lowering of sea level, which began in the late Oligocene, resulted in a comparatively small depositional area during Oligocene-Miocene time. Marine rocks were largely restricted to marginal seas of the western Pacific, the Gulf of Mexico and Caribbean Sea, and the Mediterranean Sea and the connected Alpine foredeeps. Marine sediments were also deposited 
on all continental shelves, but most of the shelves were relatively narrow. Toward continental interiors, marine deposits pass into mixed marine and continental rocks, with continental rocks becoming more abundant upward in many of the sections. Continental sediments were deposited in interior sags, in foredeeps unconnected with the ocean, and in alluvial plains along the seashores.

Dominant structural forms of the OligoceneMiocene interval reflect global Alpine orogeny. Circular sags in intermontane depressions and in deep troughs with oceanic crust (eastern Mediterranean, Black Sea) are characteristic of the interval, and foredeeps are especially abundant. Half sags dominated passive margins of continents. Linear sags, platforms, and rifts are present but are neither abundant nor extensive. Many deltas formed where passive continental margins were crossed by older rifts. These deltas represent a type of structure very important for petroleum production from Tertiary rocks.

The marine regression of Oligocene-Miocene time and the significant relief in many parts of the continents resulted in deposition of source rocks different from those of older stratigraphic intervals. Source rocks that are characterized by types I and II kerogen occupy only 16 percent of the total source-rock area. Kerogen type II dominates in some Alpine foredeeps, in the Suez basin, and in California. Type I kerogen characterizes source rocks of the rifted basins of eastern China and of some back-arc basins of Indonesia. Source rocks with type III kerogen are present in half sags, deltas, and many foredeeps, and are responsible for about two-thirds of original oil and gas reserves generated by this stratigraphic interval. Type III kerogen has not been such an important generator of oil in any other interval. Its dominance in the Oligocene-Miocene interval is mainly due to the petroleum-rich deltas, which are believed to generate most of the oil and gas produced from their sequences. In some instances, however, source rocks in these sequences are poorly defined (as in the Niger Delta, for instance; Bustin, 1988), and a deeper source for oil and gas is possible.

Source rocks are present over a quarter of the Oligocene-Miocene depositional area. The petroleum generated by these source rocks is one-third gas and two-thirds oil, and equals $\mathbf{1 2 . 5}$ percent of the world's original reserves. The Gulf Coast and Mississippi Delta contain 34 percent of petroleum generated from this interval. Source rocks containing humic organic matter are abundant in the delta and in the Gulf Coast half sag. Marine shale units that contain type III kerogen are thought to be source rocks in the Gulf Coast (Tipsword and others, 1971; Dow, 1978). However, their correlation with hydrocarbons in fields is poorly defined.
In the Oficina area of the central East VenezuelaTrinidad basin, the Oligocene-Miocene Oficina deltaic shale, which contains type III kerogen, and the middle Cretaceous Querecual sapropelic shale (La Luna equivalent; now partially destroyed) supplied oil into Miocene sandstones. In the eastern part of this basin, pre-middle Miocene organic-rich prodeltaic shale (type II kerogen) was the main source for petroleum in middle and upper Miocene deltaic sandstones (Michelson, 1976). Good marine source rocks having mixed types II and III kerogen (type III being more abundant) have been identified in the lower Miocene section of the Maracaibo basin (Blaser and White, 1984). Although geochemical data indicate a dominant middle Cretaceous (La Luna Formation) source for oil, a contribution from the Eocene and Miocene sources to petroleum reserves is probable in the deeper southeastern part of the basin.

The Oligocene-Miocene parts of the Akata and Agbada Formations constitute most of the thermally mature section of the Niger Delta. Type III kerogen and coal in this section are believed to be the sources for rich oil and gas fields (Nwachukwu and Chukwura, 1986; Ejedawe and others, 1984). However, geochemical data indicate very poor quality of the source rocks (Bustin, 1988) and suggest that a deeper, pre-deltaic source for the oil is possible. More certainly, type III kerogen in deltaic rocks is responsible for oil and gas reserves in the Beaufort-Mackenzie basin of Canada (Snowdon, 1980) and in the Mahakam basin of Borneo (Combaz and de Matheral, 1978). In both areas, the resinite component of the kerogen, which was derived mainly from the resin of coniferous trees, is a significant source for oil (Snowdon, 1980; Shanmugam, 1985).

The bituminous, siliceous Monterey Formation (Miocene) was deposited in wrench rifts of California. This diatomaceous source rock generated giant oil reserves of the region despite the small size of individual basins (Graham and Williams, 1985; Crain and others, 1985). The Monterey Formation is one of a few examples in which upwelling was probably important for deposition of effective source rocks (Demaison and Moore, 1980). Wrench rifts also controlled the deposition of Miocene and Oligocene organic-rich lacustrine shales (Pematang Brown Shale, Banuwati Shale) in several back-arc basins of northeastern Sumatra and Java. These shales, which contain type I kerogen, generated most of oil in this region. Petroleum in the less productive Ardjuna and Jutibarang basins of the same region was generated from the fluviodeltaic, coal-bearing Talang-Akar Formation (Oligocene-Miocene). These lacustrine and coal-bearing source rocks provided the bulk of the petroleum reserves of Indonesia (Kingston, 1979; Robinson, 1987; Gordon, 1985).

Conditions of Deposition of Major Source Rocks 
The North China basin is the second richest basin in China. Source rocks there are deep-lacustrine, organic-rich shales that contain type I kerogen (Lao and Gao, 1984; Li Desheng and others, 1984; Zha, 1984). The source rocks occupy a number of relatively small rifts beneath the Miocene-Pliocene sag. The precise stratigraphic position of the source rocks in the Tertiary section varies somewhat, but most of them are of Oligocene age (Huang and others, 1984). Similar source rocks of mainly Oligocene age are present also in the smaller Biyang, Nanxiang, and Jianghan basins (Tong, 1980; Li Chunju and others, 1984).

Source rocks are poorly identified in the South Caspian basin because of their deep burial in the very thick (more than 12.5 miles) sedimentary section. The main production is from the middle Pliocene deltaic sequence of the Baku and West Turkmenia regions. However, Pliocene rocks are organically very lean (organic carbon 0.2-0.4 percent) (Ali-Zade and others, 1975). Additionally, they are immature to depths of about 2.5 miles because of the low geothermal gradient (Korchagina and Zeynalova, 1986). The most probable source for the large oil and gas reserves of the basin is the Oligocene-lower Miocene Maykop Series and possibly some middle Miocene rocks. The marine Maykop Series has been drilled only in the shallower parts of the basin and in the adjacent North Caucasus region, where it is composed of similar lithofacies. The average content of dominantly sapropelic organic matter in Maykop shales is rather high (organic carbon 1.3-1.4 percent), especially in the lower part of the series, where the content of organic carbon commonly exceeds 3.5 percent (Burlakov and others, 1987). The presence of syngenetic oil pools in fractured shale reservoirs of the series suggests its high petroleum generation potential (Chepak and others, 1983; Shcherbakov and others, 1983). The Maykop Series and overlying middle Miocene organic-rich marine shales are the most probable source for the large, but now almost depleted, reserves of naphthenic oil in the Tertiary section of the Groznyi and Maykop areas in the North Caucasus foredeep.

The lower Miocene Rudeis Formation, composed of deep-water marine shales, is commonly believed to be the source for oil and gas in the Suez rift basin of Egypt (Petroconsultants, 1982; Kholief and Barakat, 1986). However, deeper Upper Cretaceous and Eocene lacustrine shales may also be responsible for a part of the oil reserves (Clifford, 1986). The petroleum pools are in carbonate and clastic reservoirs of Cretaceous through Miocene age. Oligocene organic-rich shale (menelitic shale), which contains type II kerogen, is the main source for petroleum in the Ploiesti area of Romania (Paraschiv and Olteanu, 1970) and in the Carpathian foredeep of the western Ukraine in the U.S.S.R. (Gavrish, 1985). A number of other oil and gas producing areas in which petroleum was generated by Oligocene-Miocene rocks are present around the world, but their reserves are small.

\section{MAIN FACTORS CONTROLLING DEPOSITION AND EFFECTIVENESS OF SOURCE ROCKS}

\section{Geologic Age}

It is a rather common conception that the qualitative diversity and abundance of petroleum source rocks increased through geologic time from the Late Proterozoic to the late Mesozoic and Tertiary. The well-known peak in hydrocarbon reserves in upper Mesozoic and Cenozoic rocks (Bois and others, 1982; Raaben, 1986; see also fig. 8) is considered a basis for this point of view. The evolution of life, and especially the colonization of land by plants, supposedly provided large additional amounts of organic matter to sediments that were not available before the late Paleozoic. The concept, however, seems to us to be only partially correct. Figure 4 illustrates the areal distribution of potential source rocks in the six analyzed stratigraphic intervals. (Source-rock areas were measured from the maps.) Obviously, no regular increase of depositional areas of source rock from the Silurian to the Oligocene-Miocene is observed. The maximum area of source rocks is in the middle Cretaceous interval, and the second largest is in the Silurian deposits despite the more complex tectonic history of the latter. A significant increase in area of rocks having type III kerogen and coal (which became dominant in Tertiary time) is accompanied by a decrease of area overlain by rocks containing kerogen types I and II. Because rocks with type I kerogen are rare and are not significant in the overall balance (having provided, by our estimation, approximately 2.7 percent of the original reserves of world petroleum), the relation shown in figure 4 may be interpreted as the gradual elimination of marine environments favorable for deposition of facies enriched by sapropelic (type II kerogen) organic matter, primarily the black-shale facies.

Therefore, the exceptionally large oil and gas reserves generated by the Upper Jurassic and middle Cretaceous stratigraphic intervals result not only from the widespread availability of source rocks but also from such other factors as preservation of source rocks, their late maturation, and preservation of petroleum. Figure 5 shows the relative areas of once-deposited source rocks that have been destroyed by deformation and metamorphism. Nearly two-thirds of Silurian source rocks, 


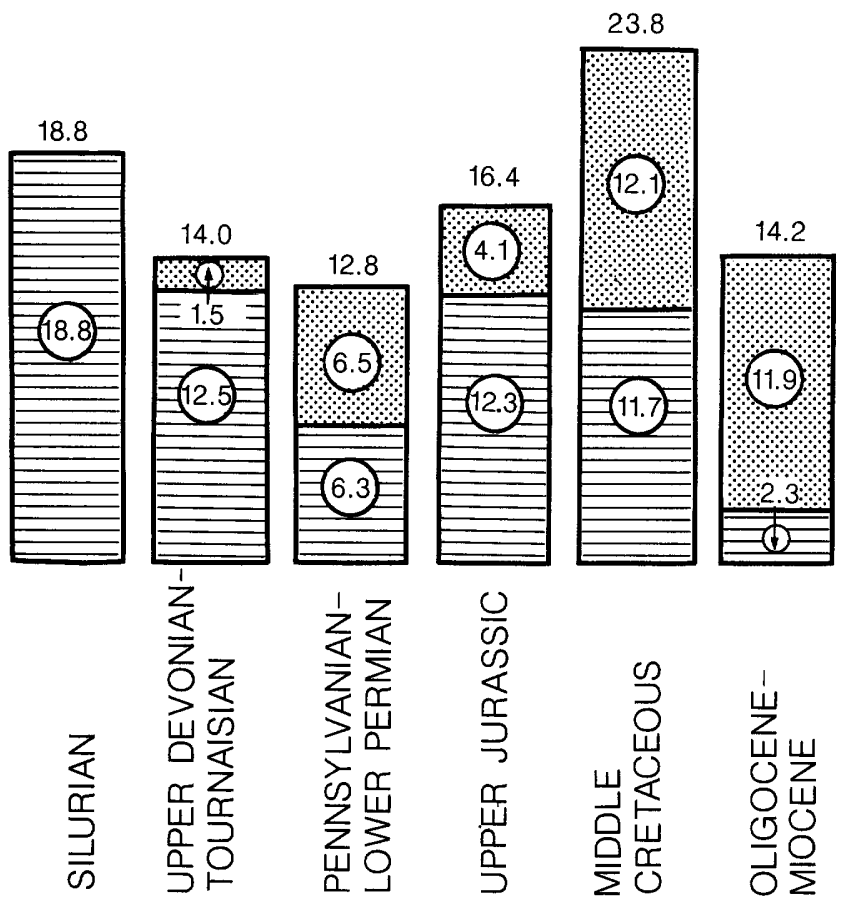

EXPLANATION

Source rocks with:

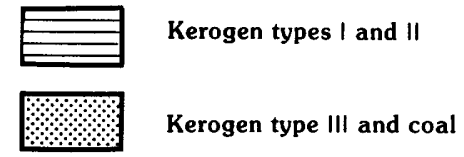

14.2 Source rock area, percent of total for the six intervals

Figure 4. Relative areal extent of petroleum source rocks, in percent of the total source-rock area for the six principal stratigraphic intervals. The areas are measured from the petroleum source-rock maps.

deposited mainly on wide platform margins of Gondwana and southern Euroamerica, have been destroyed by the subsequent splitting of northern Gondwana, by Hercynian through Tertiary accretion of Gondwana blocks onto Eurasia, and by the Hercynian collision of northern Gondwana with Euroamerica. Silurian graptolitic source rocks were also destroyed in a number of Caledonian rifts that were deformed during the Hercynian tectonic stage. The amount of destroyed source-rock area diminishes progressively through younger ages and is nearly zero for the OligoceneMiocene interval. When the destroyed areas are subtracted, the areal extent of source rocks appears to expand from the Silurian to the middle Cretaceous and then decrease in the Oligocene-Miocene because of the worldwide marine regression.

Figure 6 shows the areal extent of two groups of source rocks (those with kerogen types I and II and those with kerogen type III and coal) for the six stratigraphic

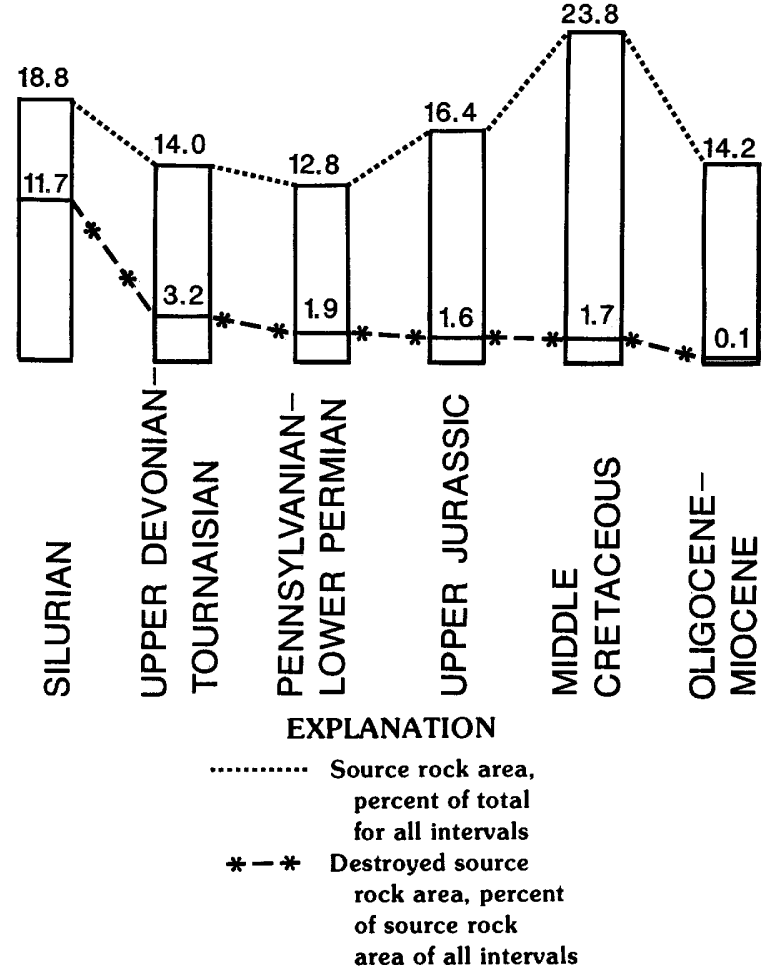

Figure 5. Relative areas of deposited and destroyed (deformed, metamorphosed) source rocks, in percent of the total source-rock area of the six principal stratigraphic intervals. The areas are measured from the petroleum source-rock maps.

intervals considered in this paper versus the effectiveness of source rocks (amount of generated petroleum reserves) for the same intervals. Both the area of source rocks for the intervals and the petroleum reserves generated by the rocks are normalized to 100 percent for easier comparison. The chart demonstrates that despite the significant amounts of oil and gas generated by kerogen type III and coal, this kerogen type is less effective than kerogen types I and II. The percentage of oil and gas reserves generated by kerogen types I and II is larger than the corresponding percentage of total source-rock area for all stratigraphic intervals except for the Upper Devonian-Tournaisian, in which the value is slightly lower. The ratio between the corresponding percentages ranges from 0.77 to 1.73 . This relation contrasts with that for type III kerogen and coal, in which this ratio varies from 0 to 0.56 . The higher petroleumgeneration efficiency of kerogen types I and II is well known from experimental geochemical studies and mass balance calculations (Hunt, 1979; Kontorovich and others, 1975). Our data show that this result is also statistically correct for geologic environments despite the fact that organic matter in source rocks almost always 
contains a mixture of kerogen types. However, usually one type of kerogen is predominant or at least more abundant, and, therefore, plays the main role in petroleum generation.

Figure 6 suggests that the statistically evaluated effectiveness of older source rocks per unit of preserved area is only slightly smaller than that of younger (Mesozoic and Cenozoic) source rocks. Most probably, this relation is due not to the lower quality of older source rocks but to the poorer preservation of oil and gas in older basins. In addition, Silurian and Upper DevonianTournaisian source rocks have been deposited over the wide platformal areas, some parts of which were not involved in basin subsidence (some areas of northern Gondwana, for instance). Kontorovich and others
(1986), by analysis of 100 petroleum basins of different ages, also show that the richness (amount of petroleum reserves per unit of rock volume) of Paleozoic and younger basins is statistically similar.

The oil-prone character of kerogen types I and II and the essentially gas-prone character of kerogen type III and coal are also well known from experimental geochemical data. The statistical verification of this difference in geologic environments is reflected in figure 7. For the Paleozoic stratigraphic intervals, the quantitative relation of oil versus gas reserves generated by kerogen types I and II appears random. This relation clearly depends on the degree of kerogen maturation in the major petroleum basins. The dependence of oil or gas predominance on the degree of maturation is especially

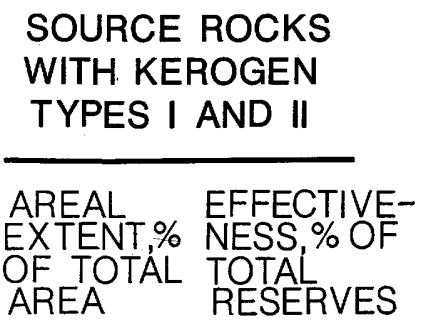

\section{OLIGOCENE-MIOCENE}

MIDDLE CRETACEOUS

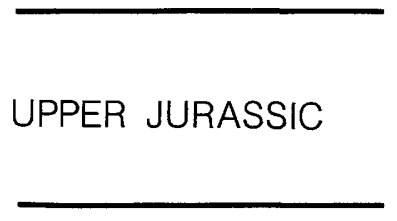

PENNSYLVANIANLOWER PERMIAN

UPPER DEVONIANTOURNAISIAN

SILURIAN
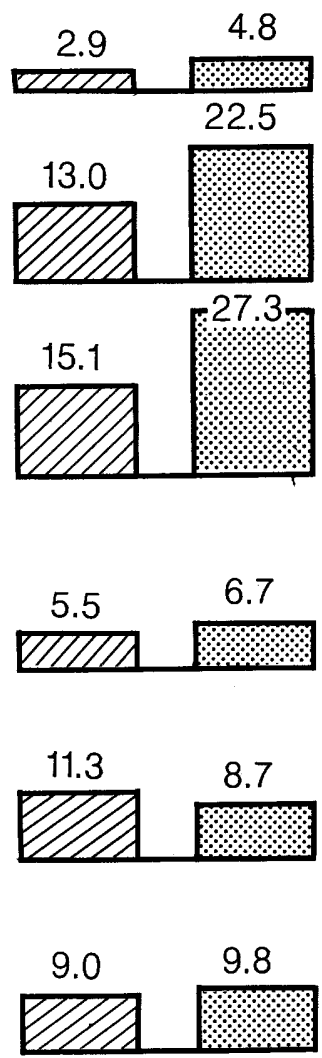

SOURCE ROCKS

WITH KEROGEN

TYPE III AND COAL
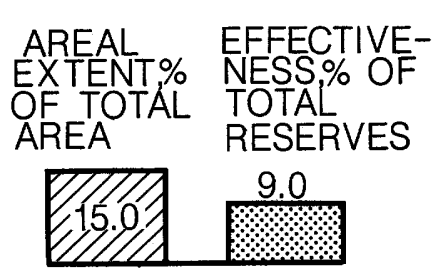

15.1
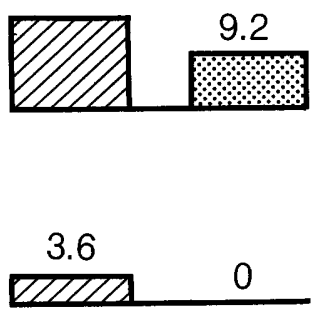

8.4
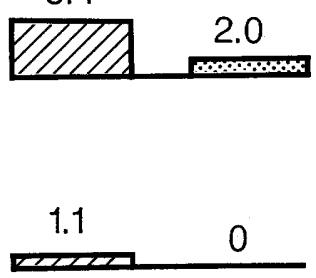

Figure 6. Relative areal extent of preserved source rocks versus their effectiveness. The effectiveness is measured in amounts of original petroleum reserves generated by these source rocks (shown on the lithofacies and structural forms maps). The total area of preserved source rocks of the six principal stratigraphic intervals and the total original reserves of petroleum generated by these source rocks are both normalized to 100 percent. 


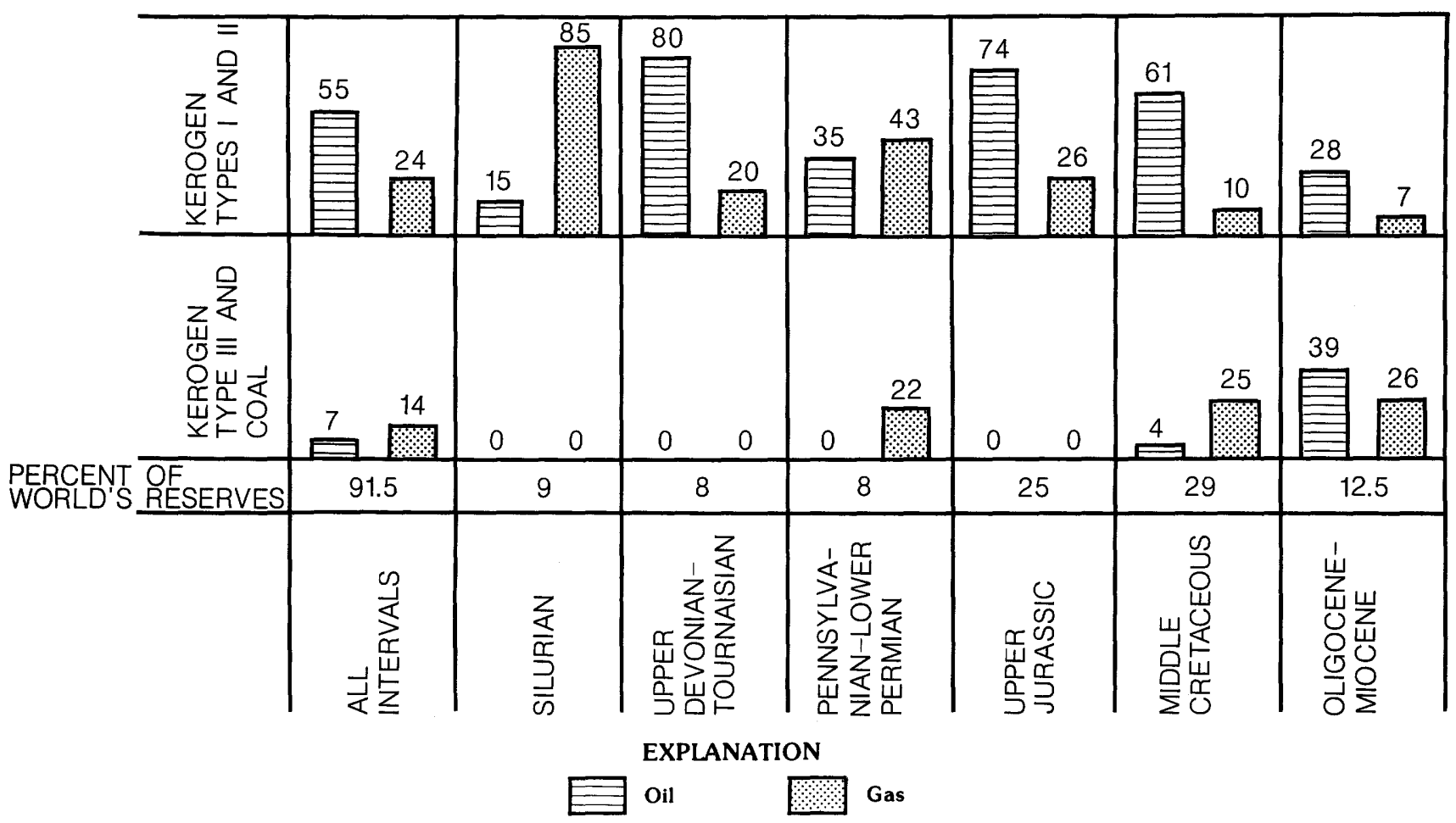

Figure 7. Oil versus gas resenves generated by source rocks with kerogen types I and II and those with kerogen type III and coal. The reserve amounts are expressed in percent of original petroleum reserves (based on barrels of oil equivalent) generated by source rocks of each stratigraphic interval.

pronounced for Paleozoic source rocks because the main reserves generated from these rocks are concentrated in only a few major basins. For example, nearly threequarters of the petroleum reserves generated from Silurian rocks are found in the Arabian-Iranian basin, where the source rocks are overmature and the dominant type of petroleum is gas. In contrast, Upper DevonianTournaisian source rocks of the North American and Russian cratons are mainly in the oil window, and most petroleum is oil. For the Mesozoic and Cenozoic stratigraphic intervals, the overmaturation problem is statistically less acute and petroleum reserves generated by kerogen types I and II are distributed in a larger number of basins. In these reserves, the share of oil significantly exceeds that of gas, as could be expected from the geochemical properties of the kerogen. In original reserves of petroleum generated by kerogen types I and II of all principal stratigraphic intervals, the amount of oil is more than twice the amount of gas.

Quite a different relation bctween oil and gas in original petroleum reserves is observed for source rocks with dominantly humic type III kerogen and coal. Although such rocks had appeared already in Late Devonian-Tournaisian time, the Chu-Sarysu basin in the Kazakh Republic of the U.S.S.R. is the only area of the world where Upper Devonian-Tournaisian rocks of this type have generated small amounts of reserves ( $\mathrm{Li}$ and others, 1982), and these are mainly gas. Beginning in Pennsylvanian-Early Permian time, type III kerogen and coal became a significant generator of petroleum. However, through the middle Cretaceous, type III kerogen and coal yielded mainly gas with comparatively little oil. Only in the Oligocene-Miocene did type III kerogen become an important source of oil in original petroleum reserves. We shall discuss this interesting change in generative potential of type III kerogen later.

The petroleum reserves generated by various stratigraphic intervals from the Late Proterozoic through the Neogene are compared with petroleum reserves entrapped in the same stratigraphic intervals in figure 8. In this chart, we combined the Oligocene-Miocene stratigraphic interval with the overlying Pliocene through Holocene deposits. Data were insufficient to assign discovered oil and gas reserves to these intervals separately. In addition, the amount of petrolcum reserves generated by Pliocene and younger sediments is trivial. Oil reserves in basal Frasnian clastic rocks (Pashiy horizon) of the Volga-Ural province were assigned to the Lower-Middle Devonian interval because they constitute a single reservoir formation with Middle Devonian sandstones. Petroleum reserves that occur in the lower Upper Permian section of the Greater Permian basin 


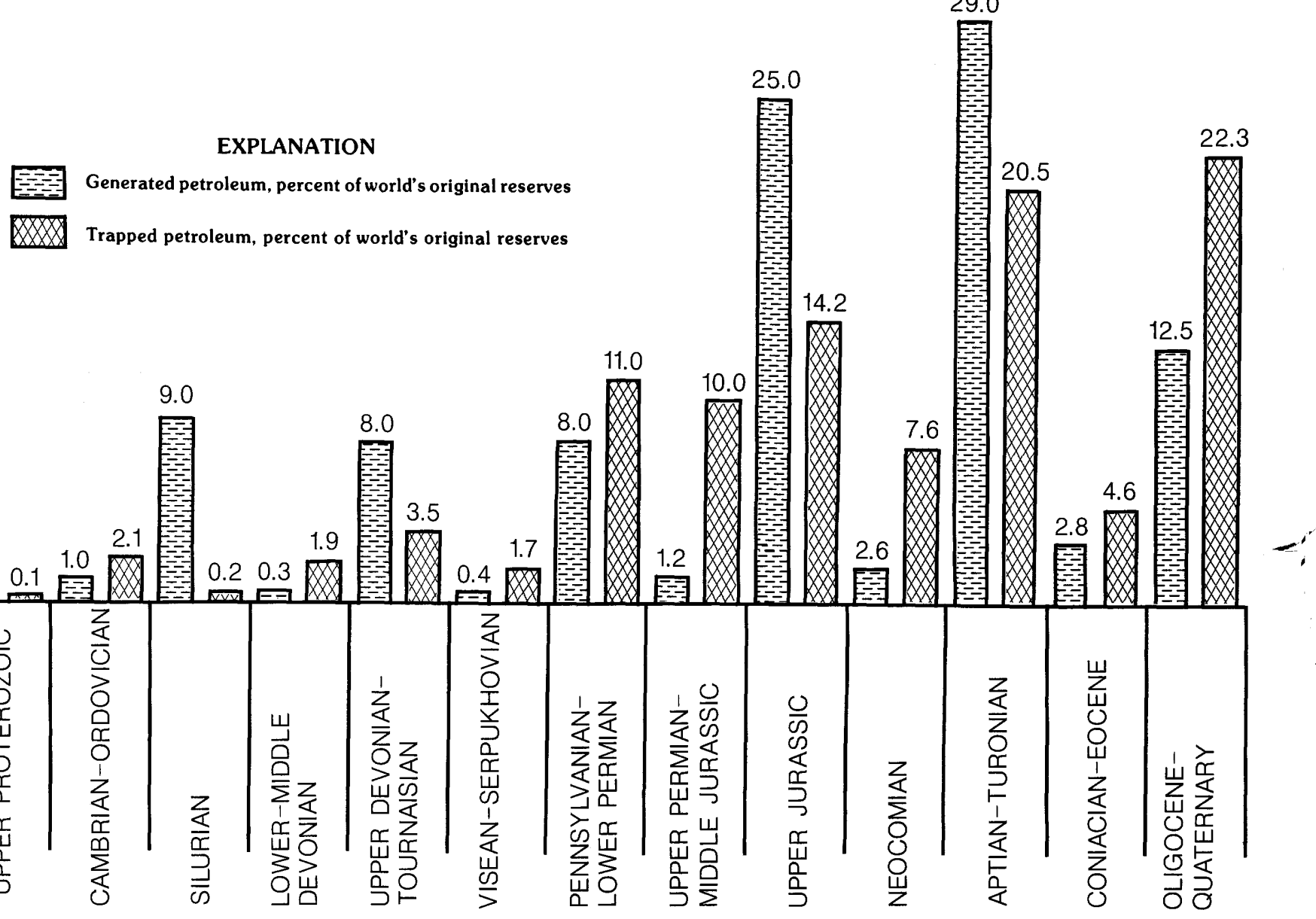

Figure 8. Original petroleum resenves generated versus those trapped in Upper Proterozoic through Quaternary strata. Total world's original reserves of petroleum are normalized to 100 percent. Reservoir formations of major petroleum basins are indicated in table 1.

(United States) were calculated together with the reserves of the Pennsylvanian-Lower Permian interval because they belong in a single reservoir sequence.

Vertical redistribution of generated petroleum in the stratigraphic succession is obvious from the chart. Of the six principal generating intervals, only two contain reservoirs for more petroleum than have been generated by these same intervals. The large reserves in the Pennsylvanian-Lower Permian reservoirs, we infer, are explained by the exceptional role of widespread Permian evaporites (fig. 3), which sealed oil and gas generated from rocks of this and older stratigraphic intervals. The youngest interval also contains more original petroleum reserves than have been generated by OligoceneMiocene source rocks. This result is partly due to large reserves in the Pliocene strata (as in the Gulf Coast and the South Caspian basin, for instance) that were aggregated in these calculations with the reserves of the Oligocene-Miocene interval. The four other principal stratigraphic intervals, although rich in entrapped oil and gas, contain less petroleum than was generated by rocks of those same intervals. In contrast, stratigraphic intervals poor in source rocks, such as the Upper PermianMiddle Jurassic and Neocomian intervals, contain large oil and gas reserves.

The direction of vertical migration of hydrocarbons generated by the six principal source-rock intervals and the stratigraphic position of the receiving reservoirs are shown in figure 9. Each number is a percentage of the world's original petroleum reserves entrapped in a corresponding stratigraphic unit and assigned to a source rock in one of the six principal stratigraphic intervals. The numbers in diamond shapes represent the portion of petroleum trapped in the generating interval. The numbers in circles represent the vertically migrated portion of petroleum.

Of course, migration into stratigraphically higher or lower strata does not necessarily correspond to actual upward or downward movement in all geologic situations. For example, in rifts, reservoir rocks on horsts were commonly filled by flow updip and through faults from younger source rocks in adjoining grabens. 


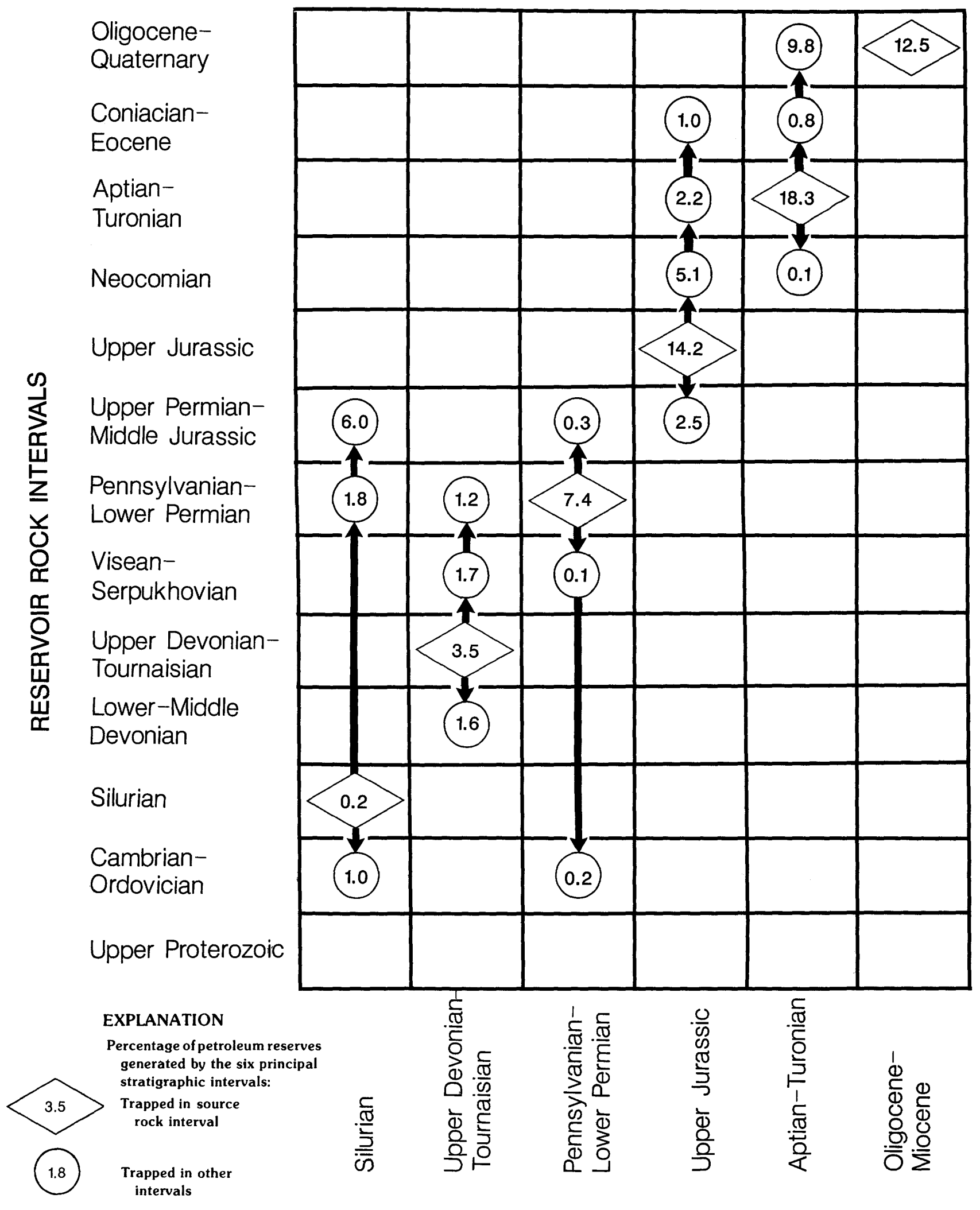

\section{SOURCE ROCK INTERVALS}

Figure 9. Vertical migration of petroleum, in percent of world's original reserves of oil and gas (BOE). The amount of migrated petroleum is calculated from the reserve occurrence data on major petroleum basins of the world and from data presented in figure 8. 
Stratigraphically downward but structurally upward vertical migration commonly occurred along unconformities. These unconformities separate two successive structural forms, such as a sag over a rift, and are conduits for migrating oil and gas. In less tectonically disturbed structural forms, such as platforms and various sags, the stratigraphic and physical directions of vertical migration are usually consistent. Because these simpler structural forms contain the bulk of world's oil and gas reserves, we consider migration into older and younger stratigraphic units as being approximately equivalent to downward and upward migration, respectively.

As is obvious from figure 9, upward migration dominates. However, the migration into older rocks is also common for the stratigraphic intervals from the Silurian through the middle Cretaceous. Very little migration into older rocks is recorded for the OligoceneMiocene interval. Such migration does occur locally, but the amount of petroleum involved is small. A good example is the Sinian (Upper Proterozoic) carbonate reservoirs in the "buried hill" structures of the North China basin, which are filled with petroleum that originated in onlapping Tertiary source rocks (Fei and Wang, 1984).

There is a principal geologic difference between the upward and the downward migration of petroleum. The vertical distance of upward migration is limited only by the presence of a reliable regional seal. Oil and gas commonly transit thick sections of rocks before being trapped beneath a seal. In the Volga-Ural province, for example, oil generated from Upper Devonian rocks (Domanik Formation) is found in all units of the overlying thick (5,000-10,000 feet) Upper Devonian through Upper Permian stratigraphic succession. In contrast, downward migration is always short-distance and reaches only as far as the reservoirs directly underlying the source rocks. This difference in the distances of vertical migration upward and downward reflects the different driving mechanisms of the migration: abnormally high fluid pressere in source rocks for the downward migration and mainly buoyancy (beyond the source rock) for the upward migration.

The characteristics of the upward and downward migration resulted in a specific stratigraphic range of petroleum productivity in each basin. In general, a productive sequence connected with one or more source rock units is restricted by a regional seal at the top and includes a reservoir rock unit directly underlying the source rock, at the bottom. A productive sequence commonly includes unconformities that are important conduits for migration of oil and gas. Therefore, productive sequences are very different from tectonostratigraphic sequences, which reflect the major tectonic stages in basin development. A productive sequence in a petroleum basin, or in a laterally isolated part thereof, was called an independent petroleum system (IPS) by Ulmishek (1986). The independence of a petroleum system is understood in the sense that the distribution of oil and gas in the system resulted from the generation, migration, entrapment, and preservation of hydrocarbons within this system and was not affected by processes occurring outside the system.

The vertical separation of a basin into IPS's may be exemplified by northern West Siberia. The lower system comprises Jurassic source rocks and the Aptian shale regional seal that controls very large accumulations of thermogenic gas condensate and smaller oil pools in Neocomian sandstone reservoirs. The upper IPS includes the Albian and Cenomanian Pokur Series, which was a source for biogenic dry gas. The gas is trapped in sandstones under the Turonian shale regional cap rock. The sealing capacity of Turonian shale is enhanced by permafrost and related gas hydrates.

A good example of the horizontal separation of a petroleum basin into IPS's is found in the North China (Huabei-Bohaiwan) basin. The basin consists of eleven Eocene-Oligocene rifts that are overlain by Neogene sag rocks. Source rocks of the Oligocene Shahajie and Dongying Formations occur in the separate rifts, each of which is an IPS. Large oil reserves have been discovered in these formations, in the underlying Kongdian Formation, and in basement rocks (Zhang, 1985).

The Arabian-Iranian basin also exemplifies the controlling role of IPS's in the distribution of oil and gas reserves. At least four systems are present. Each contains a source rock, a reservoir rock, and a regional seal, and each had its own specific mechanism of migration and entrapment. Silurian graptolitic black shale generated gas that migrated into unconformably overlying Permian and Triassic carbonate and clastic reservoir rocks. The reservoirs are capped by an extensive evaporite seal of Triassic age. This combination of source rock, reservoir rock, and seal forms a regional, stratigraphically limited IPS. The IPS has not been charged from other source rocks and has not leaked hydrocarbons outside the system.

Upper Jurassic bituminous black shale of the Arabian-Iranian basin generated petroleum that migrated into Kimmeridgian carbonate reservoirs capped by Tithonian evaporites. This is also a regionally extensive, stratigraphically limited IPS. The third stratigraphically limited system of moderate areal extent has been charged by petroleum generated from Aptian bituminous shale. The reservoir rocks are Aptian sandstones capped by the Albian shale. Aptian black shale was also the major source rock for OligoceneMiocene fractured carbonate reservoirs under Miocene salt and anhydrite in the Zagros foredeep. Probably, petroleum originally migrated into Upper Cretaceous rocks ("way stations") and later remigrated into Tertiary 
carbonate rocks after the late Tertiary folding. This combination of source, reservoir rock, seal, and traps represents an IPS of a wide stratigraphic range and a moderate, orogenically limited areal extent. The concept of IPS's has much in common with the generative basin concept of Demaison (1984). However, the IPS concept stresses the importance of regional seals and emphasizes generation, entrapment, and preservation of oil and gas in an essentially isolated fluid system.

\section{Paleolatitudes}

A warm, moist climate, characteristic of low to moderate paleolatitudes, supported abundant organic life and is believed to be a favorable factor for deposition of source rocks (Grunau, 1983). Generally, our data confirm this point of view; 66.4 percent of the total source-rock area of the six principal stratigraphic intervals was located in the tropical and temperate paleoclimatic zones, less than $45^{\circ}$ north or south of the paleoequator. Only 33.6 percent of the source-rock area was at paleolatitudes greater than $45^{\circ}$ (subpolar and polar zones). The causes of this distribution are not obvious and most probably are not connected with exclusively biologic factors. Marine tropical waters are very favorable for high diversification of life forms but not necessarily for large biomass and a correspondingly large supply of organic matter into sediments. Deposition of black-shale facies was usually facilitated by extreme abundance of a very few species, commonly blue-green (cyanobacteria) and green algae. In general, organic-rich marine rocks contain a poorer, less diversified fauna than adjoining organic-lean normal marine rocks; this relationship was well shown, for example, for Paleozoic rocks of the Siberian craton (Bazhenova, 1986). On land, extremely high productivity is characteristic of tropical rain forests. However, peat bogs and other accumulations of organic material are very uncommon there because of the high rate of decomposition of organic matter (Nikonov, 1959; Bates, 1960). An explanation for the abundance of source rocks in low paleolatitudes was proposed by Bois and others (1982), Parrish (1982), and North (1985). They suggest that conditions were favorable for formation of anoxia in the Mesogea Ocean (Tethys). For most of Phanerozoic geologic history, this ocean was located in low paleolatitudes and was significantly isolated from oxygenated polar waters by latitudinal continental barriers.

The areal distribution of potential source rocks by paleolatitudinal zones, as measured from the sourcerock maps of the six principal stratigraphic intervals, is shown in figure 10. Paleozoic source rocks with kerogen types I and II, except for those of the Silurian interval, are almost exclusively confined to the low paleolatitudinal zones. The presence of a large Silurian source-rock area in higher paleolatitudes, as discussed above, may result from the incorrect interpretation of the position of the northern Gondwana margin. Alternatively, the deposition of Silurian source rocks in high paleolatitudes might result from the dominance of graptolitic organic matter in that interval. The paleoecology of graptolites is poorly known; planktonic forms of these animals probably flourished in both cold and warm waters (Erdtmann, 1982).

Beginning with the Upper Jurassic interval, source rocks with kerogen types I and II became noticeably more common in high paleolatitudes. However, significantly larger source-rock areas still remained in the tropical and temperate zones. Source rocks deposited in high paleolatitudes are especially abundant in the Upper Jurassic. Black-shale facies of this age cover large areas of West Siberia, the Barents and North Seas, and the Sverdrup basin. Widespread deposition of black-shale facies in high latitudes during the Mesozoic contradicts the concept of Bois and others (1982), Parrish (1982), and North (1985). As discussed above, their concept connects favorable conditions for anoxia and resulting black-shale deposition with the east-to-west elongation of the Tethyan Ocean. Yet, beginning in the Jurassic, the Tethys reached its greatest latitudinal extent as a result of the splitting of northwestern Gondwana and Laurasia. The partial shift of black-shale facies into higher latitudes, which is especially significant in the Upper Jurassic interval, could be caused by the development of favorable structural forms in the northern subpolar regions, as will be discussed below.

A very different areal distribution is characteristic for source rocks that contain dominant type III kerogen and coal. These source rocks are absent in the Silurian interval and appear only in minor amounts in the Upper Devonian-Tournaisian at low paleolatitudes. Evidently, during the initial stage of their expansion, terrestrial plants were mainly or exclusively confined to the tropical and subtropical climatic zones. In the PennsylvanianLower Permian interval and in the Mesozoic intervals, the latitudinal distribution of humic organic matter (type III kerogen and coal) in source rocks is opposite to that of sapropelic organic matter. The largest depositional areas of potential source rocks with type III kerogen and coal were located in high latitudes, in the subpolar and polar climatic zones. However, during Tertiary time, source rocks containing type III kerogen and coal were again deposited mainly in the tropical and temperate paleoclimatic zones. This reverse shift of source-rock deposition was mainly due to the formation of large deltas in which type III kerogen dominates. It should be noted that the described areal distribution of source rocks with type III kerogen and coal is more conjectural than that given for kerogen types I and II because the 


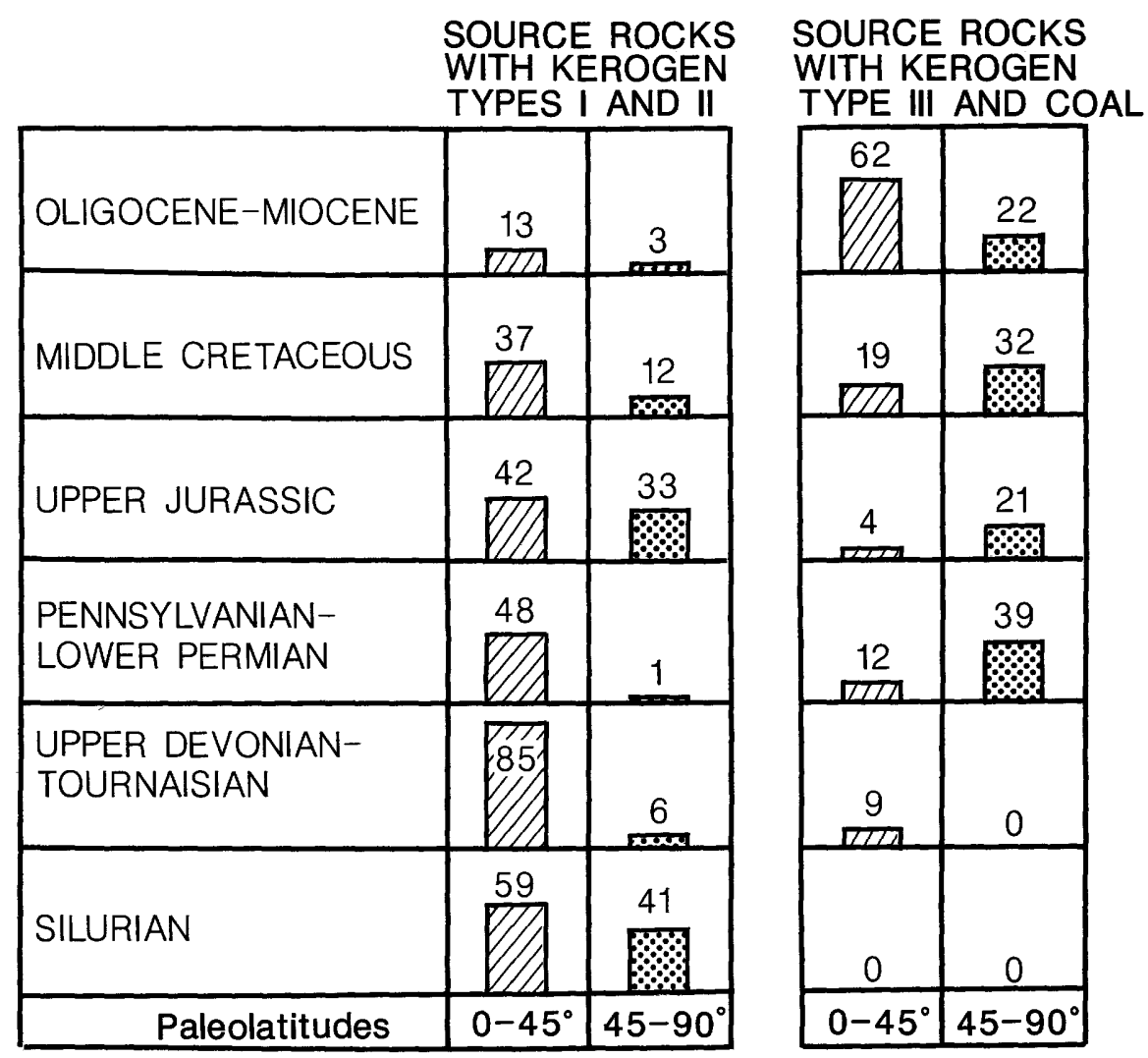

Figure 10. Relative areal distribution of source rocks of the six principal stratigraphic intervals by paleolatitudinal zones. Source-rock areas are measured from the petroleum source-rock maps. Source-rock area of each stratigraphic interval is normalized to 100 percent.

identification of potential source rocks in nonproductive areas is more subjective. Many lithologies contain moderate amounts of terrestrially derived organic matter; in most cases, however, we designated as potential source rocks only coal-bearing formations or rocks significantly (in excess of 2 percent) enriched by dispersed coaly organic matter.

A comparison of the areal extent of both designated groups of source rocks with their effectiveness (amounts of generated oil and gas reserves), in low and high paleolatitudes, is presented in figure 11. To facilitate the comparison, both the total oil and gas original reserves generated by source rocks of the six principal stratigraphic intervals and the total areal extent of these source rocks were normalized to 100 percent. Areas of destroyed source rocks were subtracted from calculations. The chart reveals a prominent feature: only for source rocks with kerogen types I and II, deposited in low paleolatitudes, does the effectiveness (in comparable units of measurement) greatly exceed the areal extent. In contrast, the effectiveness of the three other groups of source rocks is much lower than their areal extent. The result could be expected for both paleogeographic groups of source rocks with kerogen type III and coal; as was shown above, the effectiveness of these source rocks is statistically lower than that of rocks containing kerogen types I and II. But the quality of kerogen types I and II in source rocks that were deposited in high latitudes does not explain their low effectiveness. This quality is commonly very good, as is demonstrated by the Upper Jurassic Bazhenov Formation of West Siberia-one of the most efficient source rocks in the world. The higher effectiveness of source rocks with kerogen types I and II in low latitudinal zones is connected with two factors other than the quality of source rocks. The first of them is commonly high reservoir capacity due to the wide development of reefs and other carbonate reservoir rocks. Reservoirs in low latitudes include both carbonate and siliciclastic rocks. In polar and subpolar regions, however, only siliciclastic rocks are potential reservoirs, and many of them are characterized by "dirty" lithology. Another important factor is the large areal extent of salt and anhydrite in low paleolatitudes. These evaporite rocks commonly overlay large basinal areas, providing excellent regional seals. A comparable special cap rock in northern latitudes is permafrost, but only in northern West Siberia is it known to seal large gas reserves. In the geological record, permafrost is an ephemeral 


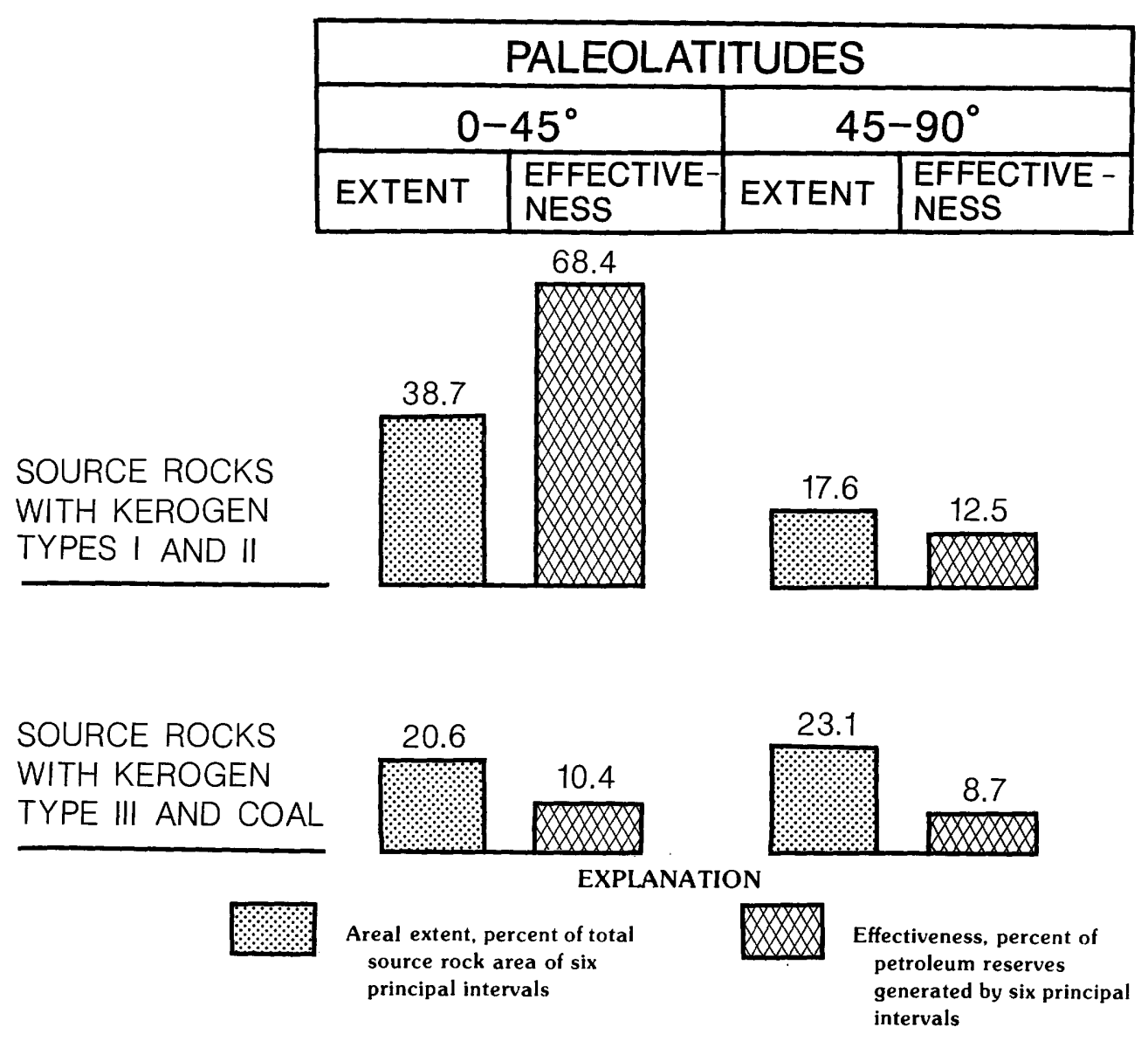

Figure 11. Relative areal extent versus effectiveness of source rocks by paleolatitudinal zones. The effectiveness is measured in amounts of original petroleum reserves generated by source rocks. Both total area of source rocks of the six principal stratigraphic intervals and total petroleum reserves generated by these source rocks are normalized to 100 percent.

phenomenon; unlike evaporites, it has controlled the migration and the preservation of petroleum only for short periods during recent time. Black-shale facies with type II kerogen, carbonate reservoir rocks (especially reefs), and overlying evaporites were commonly juxtaposed and genetically related. This common association resulted in a high endowment of oil and gas. No such genetic and spatial connection has been found between siliciclastic reservoir rocks, seals, and source rocks with type III kerogen and coal. That is why the effectiveness of these source rocks, whether deposited in low or high paleolatitudes, does not differ significantly.

\section{Structural Forms}

Structural (morphotectonic) forms reflecting tectonic stages in basin development significantly affected source-rock deposition. The structural regime controlled relief in and near areas of deposition, the distribution of sources of clastic material, and the rates of subsidence and sedimentation. Figure 12 demonstrates the effectiveness of source rocks that were deposited in various structural forms represented in the six principal stratigraphic intervals. As seen from the chart, three structural forms out of the seven distinguished in this study are responsible for the bulk of oil and gas reserves. Source rocks that have been deposited in these three structural forms-platforms, circular sags, and linear sags-provided 77.7 percent of original reserves generated by the six principal stratigraphic intervals. The four other structural forms together provided only 22.3 percent of the original reserves of petroleum.

The effectiveness of the two groups of source rocks (those with kerogen types I and II and those with kerogen type III and coal) varies differently among the structural forms. The effectiveness of source rocks with humic (type III and coal) kerogen varies relatively little in different structural forms, whereas the analogous variation for source rocks with kerogen types I and II is very significant. Petroleum reserves generated by type I kerogen are not large; in our assessment, they constitute 


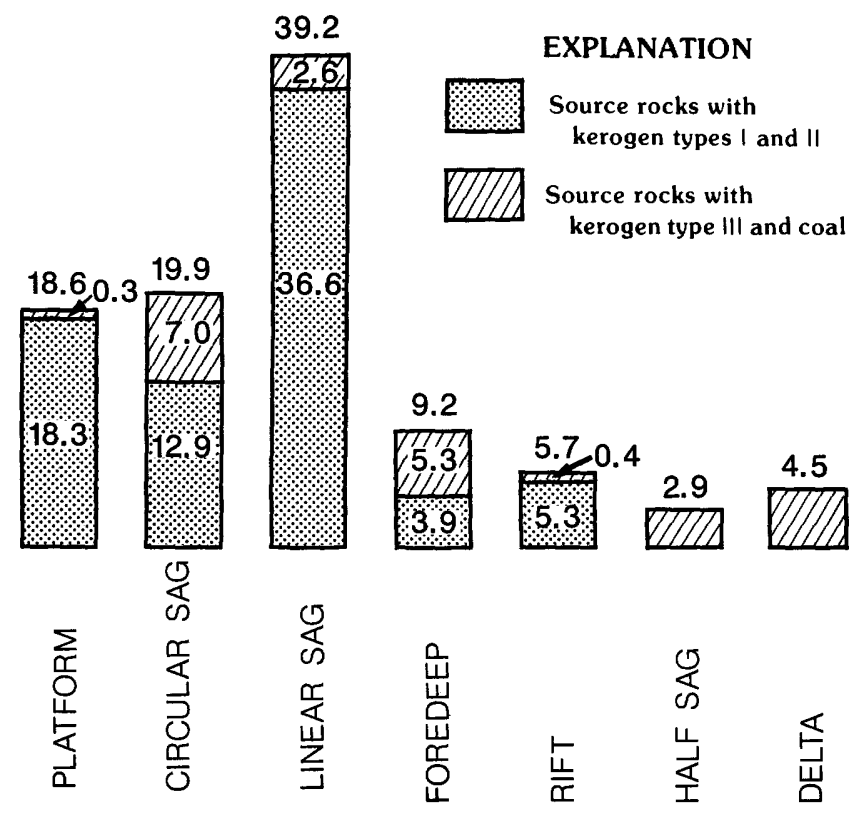

Figure 12. Effectiveness of source rocks deposited in various structural forms, in percent of original petroleum reserves generated by source rocks of the six principal stratigraphic intervals. The reserve amounts are calculated and are related to specific structural forms from data shown on the lithofacies and structural forms maps and the petroleum source-rock maps.

approximately 2.7 percent of the original reserves of world petroleum. Therefore, we conclude that structural forms controlled primarily the deposition of source rock with type II kerogen: that is, dominantly black-shale facies. These facies were deposited chiefly and, since the late Paleozoic, probably exclusively under anaerobic and dysaerobic conditions. Over geologic time, as reflected in figure 12 , these conditions have occurred preferentially on platforms and in circular and linear sags, less commonly in rifts and foredeeps, and never in deltas and half sags.

The distribution of original petroleum reserves that have been generated from source rocks deposited in various structural forms during each of the six principal time intervals is shown in figure 13. The chart reveals an interesting feature: for each of the time intervals, source rocks that generated the bulk of petroleum reserves were deposited in only one or two structural forms. Even more important is that each structural form controlled deposition of effective source rocks only during one or two time intervals. Deposition of effective source rocks on platforms occurred preferentially in the Silurian and Late Devonian-Tournaisian time intervals. Very few effective source rocks were deposited in other structural forms during these times. During the Mesozoic (Late Jurassic and middle Cretaceous intervals), the principal sites for deposition of effective source rocks were linear and circular sags; other structural forms were relatively unimportant. Half sags and deltas only gave rise to source rocks during the Oligocene-Miocene interval. The bulk of effective source rocks in rifts and foredeeps were deposited during the Pennsylvanian-Early Permian and Oligocene-Miocene time intervals, which correspond to the climaxes of the Hercynian and Alpine orogenies.

The preference of effective source rocks for rifts and foredeeps during the Pennsylvanian-Early Permian and the Oligocene-Miocene probably had a dominant tectonic cause. Rifts and foredeeps were the only structures that experienced active subsidence during the orogenic events. Thus, these structures accumulated both black-shale facies (where the subsidence rate exceeded the rate of sedimentation) and coaly clastic sediments (where the sedimentation rate was higher). Slowly subsiding platforms and linear and circular sags (except for very deep basins with oceanic crust, such as the North Caspian basin) were commonly overwhelmed by orogenic molasses. In such circumstances, these platforms and sags rarely were favorable for formation of organic-rich rocks.

The relocation of effective source-rock deposition from platforms in the early and middle Paleozoic to circular and linear sags in the Mesozoic and to half sags and deltas (depocenters) in the Cenozoic most probably was not caused by a single controlling factor. One of the factors was the tectonically controlled preservation of structural forms and associated source rocks during geologic history. Structural forms that were developed on the Silurian and Late Devonian plate margins, such as rifts, foredeeps, half sags, deltas, and many circular and linear sags, were deformed during subsequent tectonic events. Deformed structural forms of PennsylvanianLate Permian and Mesozoic ages are principally limited to half sags and deltaic depocenters, but some rifts and foredeeps were also subjected to destructive deformation. For the Oligocene-Miocene time interval, however, the whole spectrum of structural forms has been preserved everywhere except for a few areas of presently active plate margins. However, tectonic developments do not completely account for the changed role of various structural forms in source-rock deposition through time. We believe that another important cause of this change was the evolution of life on the earth.

\section{Biological Evolution}

The significance of biological evolution for the genesis of oil and gas is poorly understood. In the great majority of publications concerning paleogeographic and paleostructural conditions of source-rock deposition, the evolution of biota, although acknowledged in principle, is treated in very general terms. The event most commonly referred to is the development of higher plants on the land in the middle Paleozoic, which resulted in the 

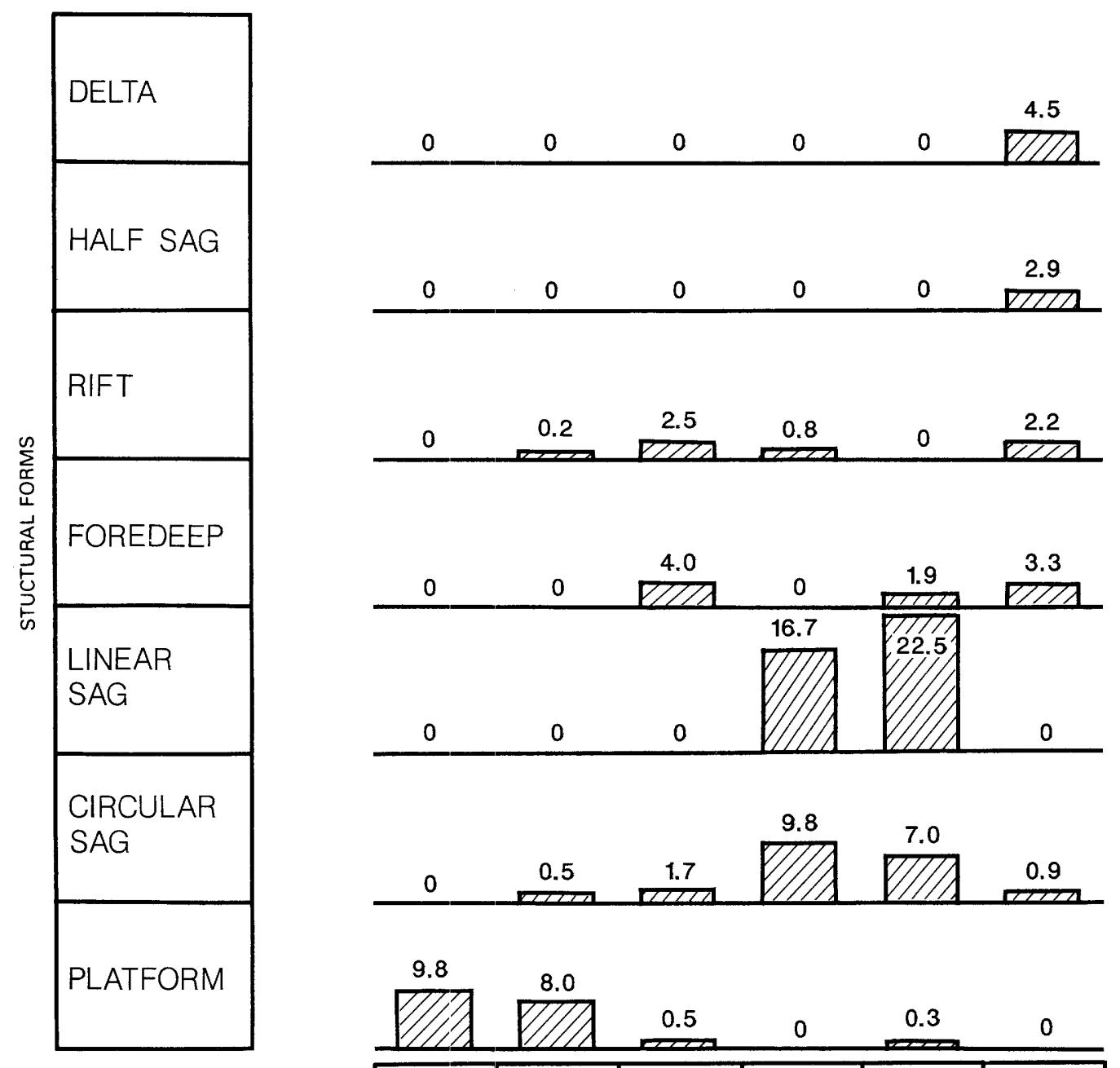

\begin{tabular}{cccccc}
0 & 0 & 0 & 0 & 0 & 2.9 \\
\hline
\end{tabular}
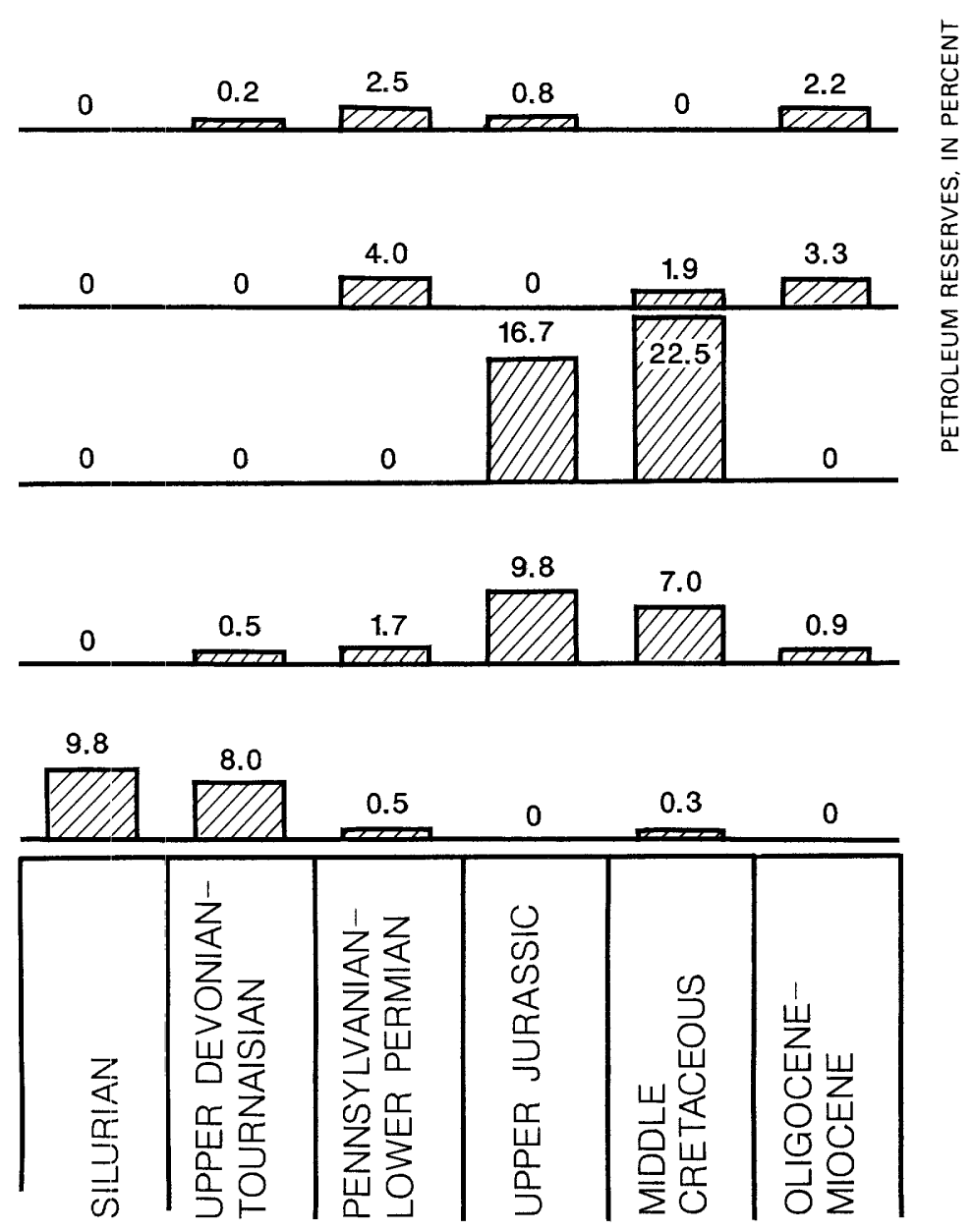

Figure 13. Effectiveness of source rocks deposited in various structural forms within each of the six principal stratigraphic intervals, in percent of original petroleum reserves generated by source rocks of the six intervals. The resenve amounts are calculated and are related to specific structural forms from data shown on the lithofacies and structural forms maps.

appearance of coal and terrestrially derived organic matter as new sources for oil and gas. The minimal attention given to paleobiological problems by petroleum geologists and geochemists probably results from the fact that organic matter in marine sediments was chiefly derived from single-cell phytoplankton during all of geologic history. It is believed that the major groups of phytoplankton (especially cyanobacteria), once they had appeared, were essentially immutable and that their basic chemical composition has changed little from at least Late Proterozoic time (Guseva and others, 1981; Stewart, 1983). Black-shale facies of different ages have a surprisingly monotonous geochemistry, and through the ages their organic matter has been derived mainly from the same groups of phytoplankton, particularly cyanobacteria (blue-green algae) and green algae (Parparova and others, 1986). However, very few publications have specifically dealt with the changes in the paleogeographic 
environments of organic-matter accumulation that resulted from the evolution of the biosphere (Bülow, 1959; Davitashvili, 1971; Eremenko and others, 1986). We will discuss here those evolutionary problems that might account for the changes in paleogeographic and paleostructural settings of source-rock deposition and that are apparent from our maps. These changes and the major evolutionary events discussed below are summarized in figure 14.

Two biological principles are important in interpreting source-rock deposition. First, every ecologic community, since at least the Late Proterozoic, consisted of three basic groups of organisms: producers, consumers, and decomposers (Bates, 1960). Producers (photosynthetic plants) synthesize organic matter from inorganic substances and provide the ultimate food base for the two other groups. Consumers (animals) eat the organic matter and are themselves organized into food chains. Much of organic matter on the land and some in the sea is not consumed in the food chains. The remaining organic matter is subjected to aerobic and anaerobic bacterial decomposition (decomposers). The bacterial decomposition, especially anaerobic, does not result in complete oxidation of organic matter. More stable components of this organic matter, such as lipids, tend to accumulate in sediments. In certain cases, bacteria themselves provide a significant share of the accumulated organic material (Tissot and Welte, 1984). In general, the loss of organic matter in anaerobic decomposition is rather small; in some assessments, it does not exceed 35 percent (Parparova and others, 1986). In the aerobic aquatic environment, the role of bacterial decomposition is restricted, and the bulk of organic matter is consumed by the metazoan population (Degens and Mopper, 1976).

The second principle is that the amount of organic matter buried in marine sediments depends little on the rate of bioproduction. This amount is controlled mainly by the balance between organic matter production and destruction (the latter includes consumption and decomposition). In many highly bioproductive areas, such as upwelling zones, the amount of organic matter buried in sediments is very low. (For example, see Hubert and others, 1977.) The inorganic oxidation of organic matter, compared with biological destruction, is highly inefficient and probably never has played a significant role in the aquatic environments. Therefore, the amount of accumulated organic matter depends

\section{TYPICAL CONDITIONS OF SOURCE ROCK DEPOSITION}

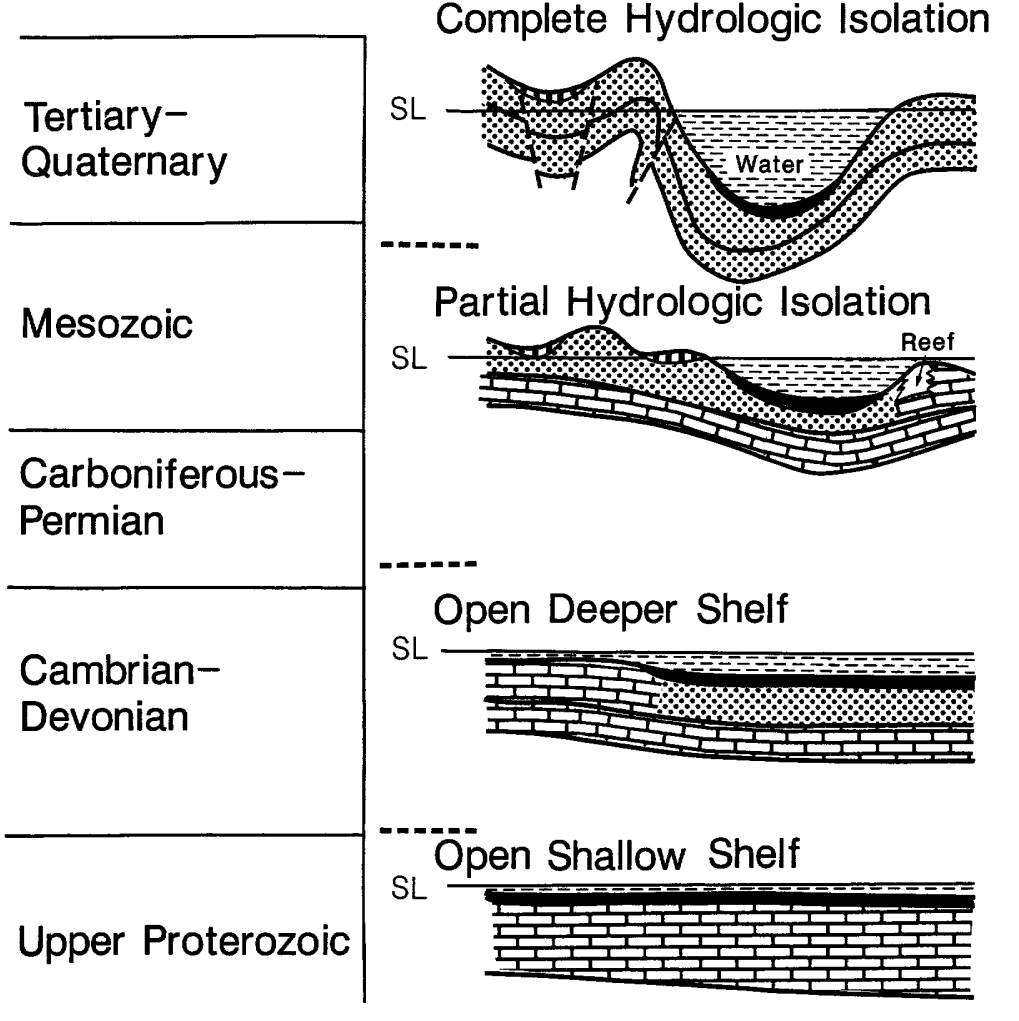

\section{MAJOR EVENTS IN BIOLOGIC EVOLUTION}
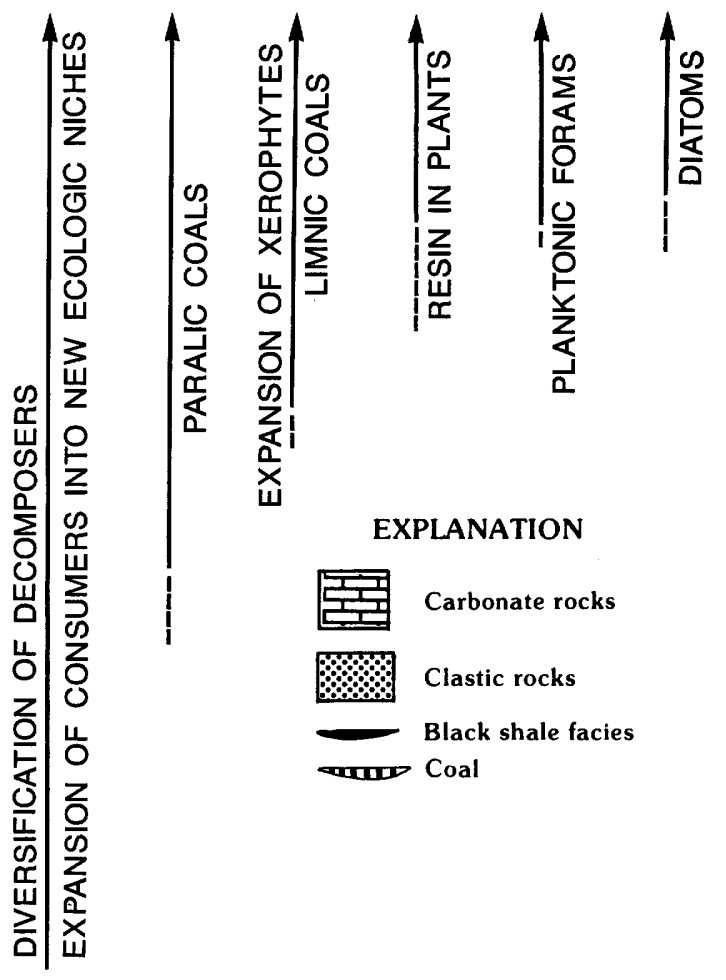

Figure 14. Changes in typical conditions of source-rock deposition through Phanerozoic time and major events of biological evolution that affected these changes. SL, sea level. 
mainly on the activity of consumers and decomposers. At present, this activity is regulated exclusively by the availability of oxygen, but it probably was not so during earlier stages of geologic history.

In terrestrial environments, aerobic bacterial decomposition of organic matter is more important than in the aquatic environments. Much of the terrestrial bioproduction (wood, for example) is not digestible for most animals and is decomposed by bacteria and saprophytic plants. In a sense, the terrestrial biosphere is underdeveloped because the evolution of consumers has not reached the point at which nearly all of the available food resource is utilized.

Conditions favorable for formation of marine organic-rich rocks in the Late Proterozoic and early Paleozoic differed from those that existed in later geologic times. Most probably, this difference was related to the level of biological evolution reached by both consumers and decomposers. In addition to the deepwater basinal facies deposited primarily in rifts (which were mostly destroyed by later deformation and metamorphism), organic-rich source rocks of Late Proterozoic and early Paleozoic age were widely formed in shallow seas on the cratons. These were commonly deposited not only under anaerobic conditions but also in dysaerobic and aerobic environments. ${ }^{9}$

Stromatolitic dolomites, which were deposited under undoubtedly aerobic conditions in shallow water, are important source rocks in the Upper Proterozoic, although organic-rich black shales are also known (for example, in the Grand Canyon area of Arizona; Reynolds and others, 1988). Unlike Phanerozoic dolomites, stromatolitic dolomites are characteristically richer in organic matter and bitumen than the underlying and overlying shales. Dolomite of the Sinian Denying Formation was the source for large gas pools in the Sichuan basin of China (Tang and Zhang, 1984). Algal dolomite of the Starorechensk Formation (Upper Proterozoic) in the north-central part of the Siberian craton was the only possible source for the large Rossokhin bitumen deposit in underlying sandstone (Klubov, 1983). Dolomite of the Riphean (upper Proterozoic) Kaltasin Formation of the eastern Russian craton is believed to be a source for oil shows in drill holes (Lagutenkova and Chepikova, 1982).

Widespread deposition of organic-rich sediments on platforms continued into the early Paleozoic. These

\footnotetext{
${ }^{9}$ In the present-day seas, the following ranges of oxygen content, in milliliters per liter, characterize environmental zones: less than 0.01, anaerobic; $0.01-1.0$, dysaerobic; more than 1.0, aerobic (Byers, 1977). The oxygen content in ancient seas was probably less, owing to the lower concentration of oxygen in the atmosphere. However, the relative positions of the zones and their effects on the ecologic communities were similar to those of the present.
}

platforms may have been slightly deeper than those of the Late Proterozoic, but they were open to the ocean, for no evidence of structural or sedimentary barriers exists. The organic-rich rocks contain some benthic organisms, many of which are eurytropic and might be able to withstand dysaerobic, but not anaerobic, conditions over the bottom. Examples are numerous and we shall mention only a few:

(1) The Middle Cambrian to Tremadocian alum shales were deposited over large areas of western Fennoscandia in a shallow sea of the then stable craton (Andersson and others, 1985). These black radioactive shales with organic carbon content as high as 20 percent locally contain brachiopods and trilobites. However, widespread lenses of organically very rich carbonate rocks (stinkstones) contain abundant and diversified benthic fauna. The absence of bioturbation in the adjoining shales and the continuation of fine lamination from shales into stinkstone lenses suggest that the anoxic/oxic interface was at, or very close to, the bottom surface. The preservation of organic matter in the fossiliferous stinkstones indicates low activity of the consumer population.

(2) The Lower and Middle Cambrian Kuonam Formation and its stratigraphic and facies analogs overlie an area of about 300,000 square miles in the northern and eastern parts of the Siberian craton. The formation is mainly composed of black and dark-brown clayey and siliceous limestones with beds of black shale. All rocks contain abundant organic matter (type II kerogen), some as much as 25 percent. On the west, the black-shale facies passes into archaeocyathan and algal limestones that form a barrier reef 15 miles wide (Zhuravleva, 1985). A giant evaporitic basin, 1,250 miles wide, was located west of the barrier reef. The Kuonam Formation contains abundant trilobites but is devoid of archaeocyaths (Bazhenova, 1986). Large benthic trilobites (Paradoxides) and brachiopods (Linnarssonia) are present in black shales together with probably pelagic trilobites (Miomera) (Pel'man, 1982). Paradoxides are especially abundant in small (commonly only $1.5 \times 3$ feet) limestone lenses among black-shale facies. These lenses also contain abundant brachiopods of the genus Arcotretidae (filter-feeders) and sponge spicules. The black-shale facies were deposited on a shelf open eastward to the ocean, probably under dysaerobic to aerobic conditions. The depth of the shelf was not great, as the Kuonam Formation is underlain and overlain by shallow-water variegated limestones with a rich benthic fauna (Bakhturov, 1985).

(3) Kukersite is probably the best studied blackshale facies of Ordovician age. This facies overlies an area of about 40,000 square miles in the Baltic region of the U.S.S.R. south of the Fennoscandian shield. The 
content of organic carbon in the black calcareous shales reaches 30 percent and more. The black shales contain an abundant and diversified shelly fauna commonly buried in live position, remnants of benthic algae, and, rarely, worm burrows. The depositional environment is interpreted as a relatively shallow but hydrologically quiet shelf with well-oxygenated bottom waters (Fomina, 1959; Raudsepp, 1959). Analogous Ordovician organicrich facies are widespread on the North American and Australian cratons (Jacobson and others, 1988). The organic matter was mainly derived from the benthic alga Gloeocapsamorpha prisca, which probably formed mats on the sea bottom.

(4) Organic-rich graptolitic shales of Ordovician and Silurian age were deposited in diverse conditions ranging from deep-water marine basins of geosynclines and rifts to shallow-water platforms on cratons. In deepwater basins, such as the Hazen rift of the Franklinian geosyncline in northern Canada, anoxic conditions dominated and a rare shelly fauna is present as redeposited occurrences (Trettin, 1978). On many platforms where planktonic graptolites are dominant, as in the Baltic region, for example, some eurytropic thin-shelled brachiopods such as Paterula are nevertheless common (Surlyk, 1980; Sokolowski, 1970). Very thin, laterally discontinuous layers of graptolitic shales occur in the Ordovician section of the eastern part of this region among light-colored shallow-water limestones (Geodekyan and others, 1976). Abundant trilobites are reported in Ludlovian graptolitic shales of the Podlyas depression in Poland (Tomczykowa and Tomczyk, 1971). Pelecypods occur with graptolites in Ordovician strata of the Taimyr Peninsula in Russia (Nikiforova and Obut, 1965). Small brachiopods, pelecypods, and ostracodes are abundant in Llandoverian graptolitic shales of the Siberian craton (Tesakov and others, 1986). Chitinozoans and pelecypods are reported in Silurian organic-rich graptolitic facies in the Kufrah basin of Libya (Turner, 1980). However, none of these graptolitic shales include a rich stenotropic shelly fauna. Dysaerobic or alternating dysaerobic and anaerobic conditions were, probably, most characteristic for the environments of graptolitic black-shale deposition.

(5) The Frasnian (Upper Devonian) Domanik Formation extends over hundreds of thousands of square miles of the Russian craton's eastern margin from the Barents Sea to the Caspian Sea. The formation is typically 70-130 feet thick and consists of dark-brown to black clayey and siliceous limestones with interbeds of marl and thin-bedded calcareous shale. The content of organic carbon is largest in the shale (to 20 percent), but the limestones are also organically rich (3-6 percent). The shale generally contains only pelagic fauna (goniatites, tentaculitids) and is devoid of bioturbation. The limestones, however, in addition to pelagic forms, contain thin-shelled brachiopods (Liorhynchus and Lingula), small pelecypods (Buchiola and Pterochaenia), and ostracodes (Entomazoe) (Mirchink and others, 1965). The ostracodes and Pterochaenia were probably epiplanktonic (sargassoid fauna). The rest of the fauna was probably benthic, indicating dysaerobic conditions, probably, with short anaerobic intervals during deposition of shale. The sea was not very deep (probably not more than a few tens of meters) because, in many areas, the Domanik Formation is underlain and overlain by undoubtedly shallow-water rocks including reefs.

(6) Upper Devonian-Lower Mississippian blackshale facies of the North American craton were deposited in conditions grading from anaerobic to dysaerobic. The areal distribution of these conditions was probably controlled by the varying water depth and the local hydrologic circulation. Mostly the depth of the sea did not exceed several tens of meters (McCollum, 1988); the shales are commonly overlain by shallow-water rocks. A lack of bottom life and complete anoxia were characteristic for the Middlesex Shale in the deeper Appalachian basin (Byers, 1977; Russell, 1985) and mostly also for the Antrim Shale in the Michigan basin (Gutschick, 1987). In contrast, a dysaerobic depositional model has been developed for the organic-rich Mississippian Delle Phosphatic Member (Woodman Formation) of the Deseret basin in Utah and adjacent States (Sandberg and Gutschick, 1979, 1984). Poor, sparse benthic fossils and signs of bioturbation indicate dysaerobic rather than anaerobic conditions in a number of other localities: in the Ohio Shale near Lake Erie (Broadhead and others, 1982), in the Grassy Creek and Blocher Shales of the Illinois basin (Bergstrom and others, 1980), in the Duvernay Formation of Alberta (Stoakes, 1980), and in the Bakken Formation of North Dakota (Webster, 1984).

The described characteristic examples indicate typical depositional environments of organic-rich marine rocks during Late Proterozoic through middle Paleozoic time. A very shallow-water carbonate, even reefal, aerobic environment of deposition was characteristic for the late Proterozoic. The concentration of organic carbon in Upper Proterozoic stromatolitic dolomites is not very large; usually it ranges from 0.5 to 1 percent. This low concentration may be due to the relatively high sedimentation rate of these dolomites and the resulting dilution of organic matter. Since Cambrian time, marine organic-rich rocks have not been formed in this environment. Cambrian and Ordovician black-shale facies were evidently deposited on slightly deeper shelves that had open connections with the ocean. The difference in sea depths from adjoining organic-lean reefal facies could be very small, as exemplified by the Kuonam Formation of the Siberian craton. The depositional environment ranged from anaerobic and dysaerobic 
(alum shales) to aerobic (kukersite). Where present, the anaerobic zone commonly was very thin, as indicated by numerous lenses of fossiliferous stinkstone among alum shales. Significantly, the anoxicity did not essentially control the organic richness of rocks; for example, kukersite, deposited in aerobic conditions, commonly contains organic carbon in excess of 30 percent. The deposition of the black-shale facies on slightly deeper open shelves continued during the Silurian and Devonian, but it no longer occurred under aerobic conditions. However, it continued to occur quite commonly in the dysaerobic environment.

The deposition of black-shale facies in the presentday seas occurs only in the anoxic environment (Demaison and Moore, 1980). Metazoan consumers and aerobic bacterial populations utilize organic matter until the available oxygen supply is exhausted. In the anoxic zone, sulfur bacteria reduce sulfates, creating poisonous hydrogen sulfide. The deposition of abundant organic material under aerobic and dysaerobic conditions during Late Proterozoic to middle Paleozoic time indicates low activity of both consumers and decomposers, which did not fully utilize oxygen and organic matter as the available energy source. The efficiency of this utilization was probably restricted by the level of evolutionary development reached by consumers and decomposers.

The Ediacara deposit of Australia is a demonstrative example of inefficient consumption of organic matter in Late Proterozoic time. The deposit is famous for the Precambrian soft-bodied fauna that occurs in shallow-water siliciclastic rocks (Glaessner, 1966). The rocks were deposited in an oxygenated, moderately turbulent environment. The excellent preservation and abundance of the soft-bodied Ediacara fauna indicates the absence or scarcity of carrion-eating animals. Especially surprising is the fact that such animals as medusids could be buried in the sediment before decomposition, which in analogous present-day conditions occurs in about 10 days (Gall, 1983). The preservation of soft bodies in Phanerozoic rocks is exceedingly rare and occurs only in very special cases. Partly this rarity is explained by higher activity of burrowing infauna in the Phanerozoic than in the latest Precambrian (Droser and Bottjer, 1988). However, even in the environments in which the burrowing activity was suppressed or absent (such as black-shale facies and other fine-laminated marine rocks), impressions of softbodied animals are rare. Since the discovery of the Ediacara fauna, similar Precambrian fossils have been found in many locations of the world: in Africa, North America, West Europe, and the U.S.S.R. (Sokolov, 1979; Fedonkin, 1987). Both the absence of the scavengers and very low activity of the heterotrophic bacterial population account for the worldwide preservation of these fossils.
Very little is known about the evolution of bacteria, although their fossils are known from rocks as old as the Archean (Schopf and Walter, 1983). It is often supposed that bacteria as well as autotrophic prokaryotes reached their high diversification early and changed little from that time (Bates, 1960; Stewart, 1983). All fossil bacteria found in rocks as old as Early Proterozoic have modern morphologic analogs (Hofmann and Schopf, 1983). However, Davitashvili (1971) showed that the expansion and diversification of bacteria should follow the evolution of other life forms and their expansion into new ecological niches. The evolution of bacteria could have proceeded through improvement in the efficiency of physiological functions rather than through morphologic changes (Tappan, 1980). Some data seemingly support this point of view. Degens and Mopper (1976) found that, even at present, the physiological activity of microbes in deep waters is about two orders of magnitude slower than their activity in shallow-water environments. The chemical mechanism for this suppressed activity is not clear; changes in the chemical structure of organic substances at great pressure may be involved. In any case, the fact may be interpreted as a demonstration of the continuous evolution of bacteria in adjusting to the high-pressure conditions at greater depth. The very good preservation of chitinous exoskeletons and even of proteinaceous skeletons of graptolites indicates relatively low efficiency of decomposers in the early Paleozoic (Kozlowski, 1966; Berry, 1987). The absence or rarity of graptolite fossils in the coral-bearing carbonate facies may result from their poor preservation rather than from a primary absence (Berry, 1962). The destruction of graptolite skeletons may have been caused not only by mechanical disintegration but also by high microbial activity in the well-aerated carbonate biotopes. Chitin does not accumulate in modern sediments, although its annual biological production is estimated to be several billion tons (Tasch, 1973). Chitin in sediments is decomposed by enzymes secreted by the chitinoclastic bacteria. It seems probable that during early Paleozoic time, these bacteria were absent outside the well-aerated biofacies environments:

The evolutionary history of worms and other softbodied burrowing deposit feeders is another insufficiently studied area of paleobiology (Robison, 1987). The fossil record is mainly restricted to tubes and jaw apparatus (scolecodonts) of polychaete annelids. Annelids are known from Precambrian strata and reached high diversification as early as the Cambrian (Glaessner, 1976). However, studies of ichnofossils provide some data on the evolutionary trends of burrowing infauna. A major increase in infaunal tracefossil diversity and intensity of bioturbation occurred during the earliest Cambrian (Crimes and Anderson, 1985). However, these changes in abundance and 
diversification of trace fossils are recorded mainly in very shallow-water facies. Droser and Bottjer (1988), in their study of Cambrian strata of the Great Basin in the United States, showed that the intensity of bioturbation diminished greatly in deeper water sediments. Highly bioturbated sediments of the inner shelf (above mean storm-wave base) pass into contemporaneous, significantly less bioturbated sediments of the welloxygenated but slightly deeper middle shelf (between mean and maximum storm-wave base). Colonization of deeper water environments by burrowing infauna, its diversification, and its efficiency in utilizing food (by improvement of feeding patterns) all increased very slowly from the Paleozoic into the Tertiary (Seilacher, 1977).

At present, worms play an outstanding role in the consumption of organic matter in the upper layer of sediments. Some observations suggest that burrowing worms pass a sediment to the depth of 2 feet through their digestive tracts twice a year (Davitashvili, 1971). Modern deposit-feeding worms, especially polychaete annelids and nematodes, tolerate widely varying oxygen concentrations. These benthic invertebrates remain active when the oxygen level drops below 1.0-0.5 milliliters per liter and the shelly fauna disappears (Rhoads and Morse, 1971). However, data on lower Paleozoic black-shale facies suggest that the ecology of ancient worms could have been different. A good example is the Upper Devonian Domanik Formation of the eastern Russian craton. Thin (often measured in centimeters) layers of bituminous black shale devoid of any signs of bioturbation are overlain by limestone beds that are also enriched by organic matter and that contain both planktonic and benthic shelly fossils. Reducing conditions inside the earlier deposited mud obviously precluded the penetration of burrowers into it, although a sufficient amount of oxygen was present in bottom water during deposition of the limestone. A rapid alternation of organic-rich black shale with greenish-gray organic-lean shale was described in the Antrim Shale of the Michigan basin (Gutschick, 1987). Each layer is only several centimeters thick but, nevertheless, the traces of burrowing are recorded only in the very thin uppermost portion of each black-shale layer. It seems likely that during the early and middle Paleozoic, deposit-feeding worms were more vulnerable to poorly oxygenated conditions than eurytropic shelly filter feeders. Low activity of the burrowing infauna strongly favored the preservation of organic matter in freshly deposited sediments.

Zooplankton and zoobenthos supplied a part of the organic matter in many black-shale facies of early and middle Paleozoic age. An especially important role probably belonged to planktonic and sessile graptolites and tentaculitids. A significant admixture of the zoogenic component is believed to result in the high content of nitrogen and sulfur and the somewhat low content of hydrogen in kerogen of many lower and middle Paleozoic black shales (Fayzullina and others, 1986; Zhuze and others, 1975; Bazhenova, 1986). The large biomass of these primary consumers resulted from the short food chains due to the poor development and low efficiency of predators. Since the middle Carboniferous, the zoogenic component has not played an important role in organic matter deposited in marine conditions.

As we've noted, the depositional environments of organic-rich sediments changed gradually from Late Proterozoic through middle Paleozoic time. The very shallow-water, probably nearshore, well-oxygenated environment of deposition was characteristic of those sediments during Late Proterozoic time. The still rather shallow-water environments varying from aerobic to anaerobic dominated the deposition of organic-rich sediments in the early Paleozoic. Dysaerobic to anaerobic environments on slightly deeper but open marine shelves were typical of the deposition of these sediments during middle Paleozoic time. Shallow-water open marine shelves are characteristic for the platforms and this explains why platforms contain the bulk of effective source rocks in the studied Silurian and Upper Devonian-Tournaisian intervals. Of course, black-shale facies were also deposited in Paleozoic deep-water stagnant basins, but these source rocks were mainly destroyed during the Caledonian and Hercynian tectonic events.

The deposition of sediments rich in organic matter on shallow-water shelves is explained primarily by the postulated low level of evolutionary development of consumers and aerobic decomposers, which commonly could not fully utilize the available resources of oxygen and organic matter. At the same time, the occurrence of dysaerobic and even anaerobic conditions on shallow shelves probably indicates the low partial pressure of oxygen in the ancient atmosphere. However, the low oxygen content may not be solely responsible for the described trend of black-shale deposition. First, blackshale deposition, at least in some cases, occurred in aerobic conditions (kukersite), and second, the content of oxygen in the atmosphere could hardly have changed significantly between Cambrian and Middle Devonian time, before the significant expansion of green plants into the terrestrial environments.

Two major evolutionary processes affected the deposition of organic-rich petroleum source rocks in late Paleozoic and later times. These processes were diversification of consumers and their expansion into new ecological niches, and evolution and expansion of plants into the terrestrial environments. These developments resulted in an attenuation of the range of conditions favorable for the preservation of organic matter in 
marine sediments. At the same time, new sources for organic matter appeared on land. Contemporaneously, effective lacustrine source rocks appeared and became increasingly important through Mesozoic and Tertiary time.

Extensive marine deposits enriched by sapropelic organic matter became very uncommon on shallow continental shelves beginning about middle Carboniferous time. The enhanced preservation of organic matter in sediments could still take place in some specific paleogeographic environments such as back-reef lagoons. However, these environments were ephemeral in time and restricted areally; therefore, the resulting deposits were unimportant as petroleum source rocks. During late Paleozoic and Mesozoic time, marine blackshale facies were preferentially deposited in deep-water (usually several hundred meters), semienclosed basins that were separated from the open sea by structural arriers or reefs. This change to a deep-water habitat can be partly explained by the increasing concentration of oxygen in the atmosphere and marine water; however, the increased efficiency of consumers, especially infauna, most probably also played an important role. Particular paleontological changes responsible for the displacement of black-shale deposition into deep-water basins is difficult to document because very little is known about the evolution of worms and bacteria. However, the gradual colonization of deep water by many groups of benthic fauna (such as brachiopods and many echinoderms) is well known. This evolutionary development may suggest that other groups of organisms devoid of hard parts could experience analogous ecological changes.

Even for late Paleozoic and Mesozoic time, the importance of anoxia for the deposition of organic-rich black-shale facies (as advanced by Demaison and Moore, 1980 , for instance) is probably exaggerated. Comprehensive paleoecologic studies of black-shale facies are rare; however, some data suggest that this facies could be deposited also in dysaerobic conditions. A good example is the Bazhenov Formation of the West Siberian basin, which is the principal source rock of this rich petroleum basin. This formation of mainly Volgian age was deposited in a marine basin that may have been 1,500-2,000 feet deep in its central part (Rudkevich and others, 1988). The deep part of the basin occupied about a half of its area, or about 400,000 square miles. The formation is $30-200$ feet thick and is composed of siliceous smectite shales containing as much as 20 percent organic carbon. The dominant fossils are the remnants of pelagic forms, but the formation contains many (in places tens of) coquinoid layers composed of Buchia and Inoceramus, commonly in live position and undoubtedly autochthonous (Vyshemirskiy, 1986). These layers are separated by intervals devoid of benthic fauna. No traces of deposit feeders are present in any of the rocks. Obviously, no hydrogen sulfide poisoning was present during deposition of the coquinoid layers; it probably developed during intermittent intervals. The anoxic zone must have been thin, considering the multiplicity of coquinoid layers (Vyshemirskiy, 1986). The absence of deposit feeders, which resulted in the preservation of organic matter, probably indicates their lower tolerance to dysaerobia compared with Buchia and Inoceramus. However, in this case the absence of deposit feeders may be explained by the low rate of colonization of the basin bottom by this group of animals after the periods of the hydrogen sulfide poisoning.

Slow colonization of the basin bottom by consumers and the resulting preservation of organic matter may be especially important for lakes. As discussed in detail by Davitashvili (1971), deep waters of young present-day lakes are commonly devoid of benthic fauna. In older lakes, the bottom fauna is sparse and consists of shallow-water forms that could adapt to the new conditions. Only in very old lakes, such as Baikal, have specific deep-water forms had enough time to evolve. For such lakes, though, even a short-term change of salinity due to climatic change or invasion of marine water, or the momentary deterioration of aerobic conditions could eliminate the whole deep-water ecologic community. The formation of a new deep-water population might take a significant amount of geologic time, during which the conditions for preservation of organic matter would be very favorable. The ecologic flexibility of producers is much higher; even after complete elimination in extreme cases, they can quickly repopulate surface waters after the reestablishment of tolerable conditions.

Beginning in about the late Late Cretaceous, the deposition of marine black-shale facies in semienclosed basins, which was characteristic for late Paleozoic and Mesozoic time, became quite uncommon. The major black-shale facies were deposited in very deep, almost completely isolated basins similar to the present-day Black Sea. The principal basins of this type were formed in tectonic depressions of the Alpine fold belt. In the semienclosed silled basins that controlled the deposition of organic-rich rocks during late Paleozoic and Mesozoic time, the black-shale facies were essentially replaced by organic-lean Globigerina ooze. Planktonic foraminifers became an important part of the pelagic fauna only in Late Cretaceous time. In the beginning of the Tertiary, three major genera of the planktonic foraminifers, Globigerina, Orbulina, and Globorotalia, rapidly evolved and expanded through all the climatic zones of the oceans (Buzas, 1987). The massive development of planktonic foraminifers probably significantly affected the bioproduction and deposition of organic matter, because the foraminifers mainly fed on the unicellular producers. 
The controlling role of planktonic foraminifers in consumption of organic matter is indicated by the fact that the facies of black shales and Globigerina ooze are mutually exclusive. A good example is the lower Tertiary section of the Caucasus region in the U.S.S.R. In the eastern North Caucasus, the Paleocene-Eocene rocks are only about 300 feet thick. The rocks were formed in a marine basin more than 3,000 feet deep in its central part (Berlin and Ulmishek, 1978). The section is chiefly composed of white Globigerina ooze, but includes a 65-foot-thick organic-rich layer in the middle part of the upper Eocene. Unlike the overlying and underlying Globigerina ooze, the black marl (Kuma Formation) contains only sparse, small planktonic foraminifers (Zhizhchenko, 1969). No tectonic or paleogeographic events that might have resulted in the depositional changes from white ooze to black marl and then back to white ooze can be identified. Probably, the foraminiferal fauna was nearly eliminated by a short-term change of salinity or a slight deterioration of the aerobic regime due to the worsening of circulation. The elimination of foraminifers could result in a sharp increase of bioproductivity of unicellular producers and intense deposition of organic matter.

The evolution of diatoms was another event important for the deposition of Cenozoic source rocks. The first indubitable centric diatoms are known from the Lower Cretaceous. However, diatoms flourished beginning in the Paleocene and especially in the Miocene, when they spread into high latitudes (Meyen, 1987; Tappan, 1980). Also during the Tertiary, pennate diatoms appeared and penetrated into fresh waters. Diatoms have an extremely high content of lipids, which reaches 40 percent of their weight (Bazhenova and others, 1986). They became an important producer of organic matter, especially in upwelling zones (such as California) and in marginal seas (such as Sakhalin).

The evolution and expansion of terrestrial plants, beginning in the Silurian, resulted in the appearance of a new source of organic matter for both continental and marine sediments. The main stages of plant evolution are well known; we shall briefly discuss only the few aspects of this evolution that were important for the deposition of petroleum source rocks. The earliest terrestrial plants were essentially amphibious and populated tidal flats and nearshore marshes. The first large trees appeared only in the Late Devonian (Archaeopteris flora); they formed forests along the river banks (Meyen, 1987). At the very end of the Devonian and during the Carboniferous, the forests slowly expanded over the slopes of hills; however, the great majority of plants still occupied a relatively narrow strip along the sea shores. Mangrove forests also appeared in the latest Devonian. This areally limited character of vegetation probably persisted during Early Permian time. The proximity of most of the late Paleo- zoic flora to the sea shores resulted in the great predominance of paralic coals during this time. Limnic coals appeared in the Late Carboniferous but became widespread in the Mesozoic and reached their maximum abundance in Tertiary time with the inland expansion of vegetation.

In the context of this study, an important aspect of plant evolution is the development of organs whose chemical composition resulted in formation of oilgenerating constituents within generally gas-prone type III kerogen. Two groups of chemical compounds are of interest in this respect: (1) waxes, which are the main precursors of paraffinic oils, and (2) resins, which generated naphthenic oils during thermal alteration (Tissot and Welte, 1984; Shanmugam, 1985).

Resins of higher plants are believed to be the source of naphthenic oils in some geologically young formations such as the Tertiary strata of the Mackenzie Delta, Canada (Snowdon, 1980; Snowdon and Powt 1982), and the Upper Cretaceous-Tertiary Latro a Group of the Gippsland basin, Australia (Shanmugan 1985). Resin is produced by trunks and branches and, to a lesser extent, by leaves of some trees. Secretion of resin is a plant's response to an external injury by physical or biological causes (feeding, parasitism). This protective mechanism evolved gradually, evidently as a response to the expansion and diversification of vertebrate feeders, insects, and parasitic fungi. Davitashvili (1971) notes that even Mesozoic fossil cycadophytes are surprisingly devoid of injuries by insects and fungi. Resin ducts in the wood did not appear in the fossil record until the Jurassic (Stewart, 1983). The main producers of resin were conifers of the family Pinaceae. The genus Pinus had evolved by the Early Cretaceous; other genera of the Pinaceae-Picea, Larix, Pseudotsuga, and a few othersdid not appear until the early Tertiary or later (Stewart, 1983). Thus, a significant content of resin in terrestrial organic matter is essentially a late Mesozoic and Tertiary phenomenon; commercial amounts of naphthenic oils derived from terrestrial sources of older age are unknown. Additionally, the development of protective resin-secretion organs was accompanied by the areal expansion of conifers. Mesozoic coniferophytes were tropical lowland plants; not until the Tertiary did they expand into high latitudes and uplands (Hughes, 1973). Since at least the end of the Paleogene, the Pinaceae have played the paramount role in the terrestrial vegetation (Meyen, 1987).

Waxes in the higher plants form a layer (cuticle) over the stem, leaves, and fruits, which protects these parts from mechanical injuries and desiccation. The derivatives of plant waxes and other lipids and lipid-like substances during diagenesis form liptinite (exinite), which is the main precursor of oil from terrestrially derived organic matter. Liptinite is present in coal and 
coaly organic matter of rocks as old as the Devonian; well known, for example, are upper Paleozoic cannel coals essentially formed by spores. Thick cuticles of leaves were characteristic of some Paleozoic plant groups, such as Westphalian cordaites. Despite early development, such protective tissues remained relatively unimportant through most of the Paleozoic; their importance (and probably their abundance) increased very gradually as the plants adjusted to more arid environments. The main groups of the coal-forming Carboniferous flora were dwellers of nearshore swamps. Allochthonous remains of xerophytic plants that supposedly grew on low hills are known in some Carboniferous coal measures-for example, in the Donets coal basin of the U.S.S.R. (Fisunenko, 1964). However, the dominant flora consisted of hygrophilous plants.

The xerophytic character of late Paleozoic and probably early Mesozoic plants does not necessarily suggest climatic conditions as arid as those implied by present-day xerophytes. Early plants that conquered previously uninhabited areas, even with sufficient amounts of rainfall, probably had a xerophytic character. The xerophytism is a relative feature, depending on the evolutionary level reached by plants (Davitashvili, 1971). In the late Paleozoic and early Mesozoic, plants with a xerophytic habitus may have grown in rather humid environments. Additionally, the development of soils affected the character of the plant population. The effect of soil development is well demonstrated by the colonization of Krakatoa Island west of Java after the volcanic explosion and complete destruction of life in 1883. Several years after the disaster, the biological desert was colonized by mainly xerophytic grasses with some shrubs and ferns on hills (Richards, 1952). Only in 1932 was the savanna replaced by a mixed forest, which will supposedly give way to a stable rain forest in the future. This change of vegetation resulted from the formation of soil, which took significant time despite the very good substratum (volcanic ash) and the abundance of moisture. Krakatoa Island may present a model for the colonization of previously barren lands by late Paleozoic and early Mesozoic plants.

The latest Paleozoic and early Mesozoic colonization of vast land areas by plants caused some general changes in the character of continental sedimentation that affected the deposition of source rocks. A developed forest stabilizes river channels and prevents the erosion of soils. It is believed that before the late Paleozoic, permanent rivers were rare, and the bulk of clastic material was transported by ephemeral streams (Davitashvili, 1971; Lindsay, 1987). The forestation of inland areas resulted in landscape types that had been absent or uncommon in earlier times. Of special interest here are forest lakes surrounded by swamps. The organic matter deposited in such an environment was mainly derived from terrestrial plants but contained an essential aqueous admixture chiefly from unicellular algae. In places, beds highly enriched by organic matter from planktonic algae (gyttja) were deposited (Dean and Fouch, 1983). These lakes were quite ephemeral and quickly became peat bogs. Interlayers of lacustrine rocks in the resulting coal-bearing sequences now contain type I kerogen, which can provide an oil source in a generally gas-prone section.

The discussed evolutionary changes in plants and the inland expansion of forests resulted in the gradually rising content of resins and probably also waxes in terrestrial organic matter. At the same time, the amount of type I kerogen in organic matter deposited in humid climatic conditions increased. These changes can account for the increasing proportion of oil in petroleum that was generated from source rocks containing dominant type III kerogen from the late Paleozoic through the Tertiary.

The considerations discussed in this section suggest an important role for biological evolution in deposition of source rocks during latest Proterozoic and Phanerozoic time. The effect of biological evolution on source-rock deposition was principally expressed as two opposing developmental trends. On one hand, the evolution of producers and their expansion into new ecological niches, both in the sea and on the land, increased the areas of bioproduction. The diversification of producers widened the range of organic matter types available for accumulation in sediments in favorable conditions. On the other hand, the evolution of consumers and probably also decomposers resulted in more complete utilization of organic matter as food. This development brought about a change in the environments suitable for deposition and preservation of organic matter in sediments. The range of environments favorable for deposition and preservation of organic matter with type II kerogen was significantly attenuated, and, hence, the marine black-shale facies gradually lost their role as the most prolific source rock for petroleum resources. In the Tertiary, this role was passed to source rocks with type III kerogen and coal.

\section{Maturation of Source Rocks}

The time of maturation of effective source rocks is not shown on the maps; however, it is indicated in the descriptions of the main petroleum basins in table 1 . The diagram in figure 15 demonstrates oil and gas reserves generated by each of the mapped stratigraphic intervals during consecutive periods of source-rock maturation. Maturation is a long process that commonly embraces more than one time interval. In figure 15 , we placed the reserve amount generated by a specific source rock into that time interval when this source rock entered the oil 
window or, if the reserves are dominated by thermogenic gas, the gas window. Even with this approach, the cases in which a source-rock formation entered the oil window during two and even three subsequent time intervals in different parts of a basin are common. The length of maturation time depends on the tectonic nature of a basin. Long maturation periods were characteristic of source rocks deposited on platforms and in many sags. In contrast, source rocks in rifts and foredeeps subsided rapidly and reached maturation within geologically short times. To relate a certain reserve amount to each of subsequent maturation periods is difficult, and simplifications are unavoidable. For this reason, the reserves related to a certain age of source-rock maturation are shown in figure 15 as ranges of percentages from the total reserves that were generated by the source rocks of each interval. Thus, figure 15 reflects the general tendency in timing of maturation rather than the exact amounts of petroleum generated at a specific time.

The time of oil and gas generation by source rocks cannot always be equated with the time of formation of known fields. Under certain conditions, oil generated in source rocks can be retained in these rocks for a long time. This situation may occur when source rock is separated from reservoir rock by an impermeable seal.
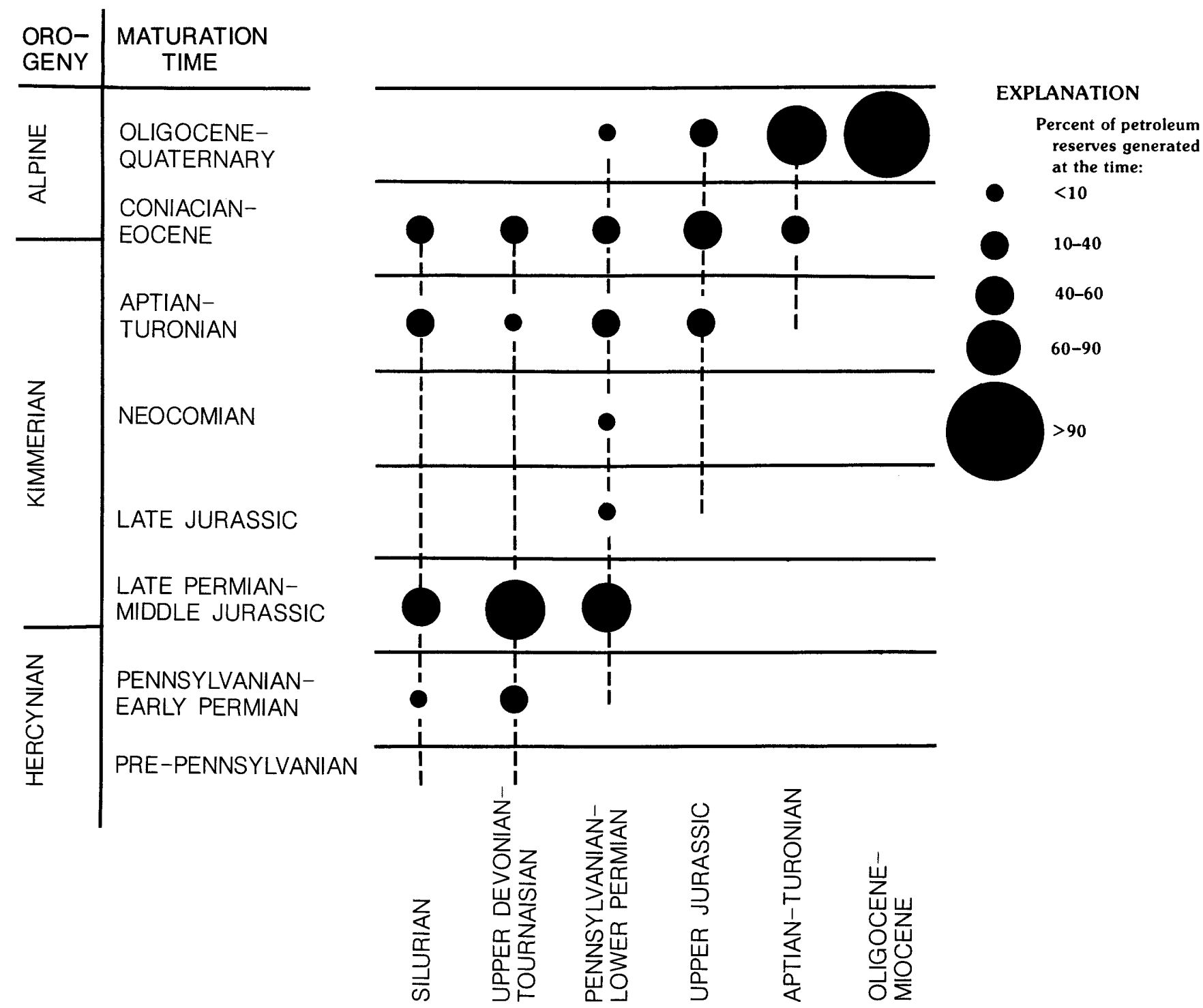

SOURCE ROCK INTERVAL

Figure 15. Maturation times of effective source rocks. Original petroleum reserves generated from source rocks of each of the six principal stratigraphic intervals are normalized to 100 percent. Maturation times for major petroleum basins are indicated in table 1. 
The oil thus confined can be released later if the seal is fractured by tectonic and other processes. Such long retention of oil probably occurred in the Upper Devonian Domanik facies of the Volga-Ural and TimanPechora basins (Ulmishek, 1988). Intense generation of oil and gas can result in overpressuring of source rocks, causing their massive fracturing. The fracturing results in the formation of reservoirs within the originally impermeable source rocks. This process evidently took place, for example, in the Monterey Shale of California and in the Bazhenov Formation of West Siberia. On the other hand, some newly generated oil and gas may have migrated into temporary traps (commonly stratigraphic) that existed during the maturation time ("way stations"), and then remigrated during later tectonic activations that formed new structural traps. Associated fracturing of sedimentary rocks provided the migration paths. This Wyo-stage migration is probable, for example, in the Zagros fold belt of the Arabian-Iranian basin.

Despite these complications, figure 15 reveals some interesting peculiarities. The first that draws attention is that only small amounts of original oil and gas reserves were generated before Late Permian time, and essentially none before Pennsylvanian time. The Late Permian-Middle Jurassic time interval was a significant stage of petroleum generation by Paleozoic source rocks. These source rocks reached maturity in such large petroleum regions as the Volga-Ural, Timan-Pechora, North Caspian, and Dnieper-Donets basins in the U.S.S.R., as well as in the Appalachian, Anadarko, Arabian-Iranian, and southern North Sea basins. Much of the maturation resulted from the deposition of thick Hercynian and early Kimmerian molasses and the resultant deep burial of source rocks.

Surprisingly little oil or gas was generated during the Late Jurassic and Neocomian time intervals. Only the Permian source rocks in the Vilyuy basin in eastern Siberia reached maturity in this time. Active generation of petroleum began again in middle Cretaceous (AptianTuronian) time. However, the main amounts of presently known original reserves of oil and gas were generated between the Coniacian and the Holocene. The deposition of thick molasses, this time connected with the Alpine orogeny, again played the major role in the burial and maturation of source rocks. Thus, our data indicate that the majority of oil and gas is of very young age. About two-thirds of original oil and gas reserves were generated and trapped during latest Cretaceous and Cenozoic time, or over the last $80-90$ million years - a rather short interval of the Phanerozoic geologic history. Most of this oil and gas was generated from source rocks of the Upper Jurassic, middle Cretaceous, and Oligocene intervals. The share of young oil and gas is actually even larger because we assigned the reserves in each basin to the time interval when maturation began, even though this process commonly continued through more than one time interval. Taking this into account would shift some of the reserves to younger ages.

\section{SUMMARY}

More than 90 percent of original recoverable reserves of oil and gas in the world have been generated by source rocks of six stratigraphic intervals: the Silurian, Upper Devonian-Tournaisian, Pennsylvanian-Lower Permian, Upper Jurassic, middle Cretaceous (AptianTuronian), and Oligocene-Miocene intervals (fig. 1). Together, these stratigraphic intervals represent about a third of Phanerozoic time. Source rocks deposited during the other two-thirds of Phanerozoic time are responsible for only 8.5 percent of the world's oil and gas reserves. The concentration of source rocks in several relatively narrow stratigraphic intervals obviously does not result from a single cause because the areal distribution, the preference for specific morphostructures, and even the geochemical character of source rocks changed significantly from one interval to another. Silurian, Upper Devonian-Tournaisian, Upper Jurassic, and middle Cretaceous source rocks were deposited during worldwide marine transgressions. In contrast, the deposition of Pennsylvanian-Lower Permian and Oligocene-Miocene source rocks took place during marine regressions. Favorable combinations of a number of different factors-tectonic, stratigraphic, climatic, hydrologic, and biological-resulted in wide distribution and high effectiveness of source rocks of the six principal stratigraphic intervals. Thus, the intermittent appearance of widespread effective source rocks may not be considered a consequence of any kind of cyclic geological processes.

The model of an oceanic anoxic event was recently discussed in many publications (Demaison and Moore, 1980, and Tissot and others, 1984, for instance) to account for the deposition of middle Cretaceous black shale facies. The model suggests that the oxygendeficient layer rose and onlapped onto the slope and even the continental shelf. Middle Cretaceous black shales in the Atlantic Ocean are well documented by cores of the Deep Sea Drilling Project; these shales were deposited during early stages of the opening of the Atlantic, when the ocean was actually a Red Sea-type rift and was significantly shallower than at present. The narrowness of the middle Cretaceous Atlantic is emphasized by the abundance of terrestrial organic matter in bottom sediments, indicating the proximity of provenance areas.

As was noted above, petroleum reserves in the rifted marginal basins of Africa and South America were not generated from stratigraphic analogs of the Atlantic's black shales. Source rocks in those basins occur in the 
rifts and at the base of sag sequences immediately above the rifts. They were deposited before the opening of the ocean. Neither can the anoxic ocean model account for other major deposits of the middle Cretaceous blackshale facies. This facies in the Arabian-Iranian basin, for example, is separated from the open ocean by a reefal carbonate platform, which shows no signs of anoxicity on its oceanic slope. Thus, the black shales in the basin have nothing to do with the oxygen regime in the paleo-ocean.

Upper Jurassic black shales have an exceptionally wide distribution in the Arctic, where they are present in the West Siberian basin, on the Barents and North Sea shelves, and in the Sverdrup basin (pl. 4C). Their deposition could have resulted from an anoxic event in the Paleo-Arctic ocean. However, the silled deep basin model is clearly more appropriate to explain the deposition of black-shale facies in other regions, such as the Arabian-Iranian basin and basins of the Alpine system. These basins were separated from the open oceans by carbonate platforms and reefs.

Anoxicity certainly was not widespread in oceans during Oligocene-Miocene time, when the paleogeography (pl. 6A) was rather similar to that of the present. Also, there are no reasons to suppose an oceanic anoxic event for the Pennsylvanian-Early Permian time interval. During this time, the glaciation in the southern hemisphere (as shown by the tillite boundary in fig. 3) and a steep temperature gradient between the polar and equatorial regions should have produced a vigorous water circulation in oceans. As to early and middle Paleozoic time, any suppositions on the oxygen regime in the oceans are highly speculative and are not supported by actual data. However, the existence of anoxic conditions is very improbable at least in the Paleo-Pacific because of its tremendous size and openness to polar latitudes. Thus, the deposition of Upper DevonianTournaisian black shales in Euroamerica (pl. 2C) was not a result of anoxicity in the ocean. However, anoxicity in the Silurian Proto-Tethys, bounded by continents on the north and the south, seems to be possible (pl. 1C).

Upwelling, although responsible for the deposition of some oil-source rocks such as the Lower Permian Phosphoria Formation (Parrish, 1982), does not seem to be a universal or even important mechanism of sourcerock deposition. The majority of effective source rocks were deposited under stagnant hydrologic conditions in structural forms that were effectively protected from the open-ocean circulation. The relative insignificance of upwelling is illustrated by the low productivity of half sags, which are more subject to the influence of upwelling than other structural forms.

Volcanism is another important source for the supply of nutrients into marine water. The flourishing of phytoplankton and the deposition of organic matter seem to be consequences of intense volcanism. The distribution of organic carbon in the upper MesozoicCenozoic stratigraphic units of oceans was studied by Trotsyuk and Marina (1988), who found a statistical correlation between the concentrations of organic carbon in these units, on one hand, and the volumes of volcanic rocks on continents and the rates of formation of new oceanic crust in oceans, on the other hand. It is difficult to extend this correlation back through Phanerozoic time. No reliable assessment of the rates of sea-floor spreading is yet available for Paleozoic-early Mesozoic time. As for volcanism on continents, the peaks of volcanic activity occurred during Middle Ordovician, Early Carboniferous, Early Permian, Late Triassic, and Cretaceous times (Budyko and others, 1987). These times do not correspond to the time intervals of deposition of effective source rocks. Our data also indicate the absence of any obvious correlation between regions of intense volcanism and source-rock depositin As a matter of fact, source rocks were more commonly deposited on passive continental margins and in intracratonic basins, whereas intense volcanism was more characteristic of active continental margins. Of course, none of the listed causes had any effect on the deposition of terrestrial and lacustrine organic matter, which was controlled by climatic and tectonic factors.

The most important change in the character of petroleum source rocks during the Phanerozoic was the appearance and expansion of source rocks containing type III kerogen and coal. The effectiveness of source rocks with type III kerogen also grew and reached its maximum in the middle Cretaceous and OligoceneMiocene (fig. 6). However, the expansion of source rocks containing type III kerogen and coal was accompanied by the decrease of areal extent and effectiveness of source rocks with type II kerogen, primarily black-shale facies. Although Mesozoic and Cenozoic rocks generated the largest share of the world's original oil and gas reserves, this is not a consequence of the better quality of source rocks of this age. Rather this is a result of better preservation of both source rocks and oil and gas fields in younger strata. The better preservation, as is seen from the maps, is also reflected in the constantly increasing number of basins that have effective source rocks, from 4 in the Silurian to 35 in the Oligocene-Miocene. However, only a few major basins contain the bulk of petroleum reserves generated by source rocks of each stratigraphic interval.

The stratigraphic distribution of entrapped petroleum in the Phanerozoic sequence is less uneven than the distribution of effective source rocks, owing to the widespread vertical migration of oil and gas (figs. 8 and 9). Upward migration is more common but downward migration also played an important role. The stratigraphic and physical distance of upward migration was controlled only by the presence of regional seals. In 
contrast, downward migration went no farther than the directly underlying reservoir rocks (sometimes stratigraphically much older if separated by an unconformity).

Low latitudes, on average, were significantly more favorable for deposition of effective source rocks with kerogen types I and II (fig. 10). In contrast, more source rocks containing kerogen type III and coal were deposited in high latitudes during late Paleozoic and Mesozoic time. Only in Oligocene-Miocene time were these source rocks mostly deposited in the tropical and subtropical zones, mainly owing to the formation of large deltas. The relative effectiveness of these two groups of source rocks (the amount of generated petroleum reserves per unit of source-rock area) demonstrates different trends (fig. 11). Source rocks containing kerogen types I and II in low latitudes $\left(0^{\circ}-45^{\circ}\right)$ were generally more effective than the same source rocks in high latitudes $\left(45^{\circ}-90^{\circ}\right)$. They were also more effective than source rocks with type III kerogen and coal in both latitudinal zones. This high effectiveness is interpreted to result not only from better quality of kerogen types I and II, but also from abundance of carbonate reservoir rocks and evaporite seals in low latitudes.

The high effectiveness of source rocks with type II kerogen that have been deposited in low latitudes resulted in rich oil and gas reserves of the Tethyan realm-a succession of Silurian to present latitudinal seaways between Gondwana and the northern group of continents. This realm possessed above-average reservoir potential owing to formation of thick carbonate rocks in addition to sandstone reservoirs. The realm also fostered the deposition of evaporites, which provided for both excellent seals and salt-associated traps. In addition, the successive rift openings and collisional closings of the Proto-, Paleo-, and Neo-Tethys developed rift/sag structural forms favorable for the development of silled basins and the deposition of source rocks. The region in which the Tethyan basins developed includes only a quarter of the world's lands and continental shelves, yet they contain more than two-thirds of the world's original petroleum reserves.

Platforms open to the oceans were the principal structural form that controlled the deposition of source rocks during early and middle Paleozoic time (fig. 13). During the Mesozoic, the principal source-rock deposition shifted to silled basins located in circular and linear sags. In the Pennsylvanian-Early Permian, rifts and foredeeps were the dominant structural forms that hosted the deposition of petroleum source rocks. In the Oligocene-Miocene, the source-rock deposition was controlled by these same two structural forms and also by deltas (depocenters) and half sags. In general, the distribution of source rocks in different structural forms was controlled by the global and regional tectonic conditions, the state of biological evolution, climate, the oxygen content of the water, and other environmental factors.

Biological evolution played an outstanding role in the history of source-rock deposition during Late Proterozoic and Phanerozoic time. Different groups of producers evolved and colonized new ecological niches, both in the sea and on the land (fig. 14), thereby expanding the areas available for accumulation of organic matter in sediments and widening the range of organic matter types. However, consumers and probably decomposers also evolved during this time. Their evolution changed the ecologic systems and resulted in the gradual attenuation of the range of conditions suitable for the deposition and preservation of organic matter in sediments, especially marine organic matter with type II kerogen. The rising oxygen content in the atmosphere also may have had a negative effect on the preservation of organic matter. These two opposed processes-the areal expansion of production of organic matter and the restriction of conditions suitable for its preservation-resulted in a drastic change from source rocks with exclusively marine sapropelic organic matter in the early Paleozoic to source rocks with dominant terrestrial organic matter in the Tertiary. Figuratively speaking, we are geohistorical witnesses to the extinction of the marine sapropelic source rocks that generated most of the known oil and gas. The basic reason for this extinction is the evolution of the biosphere toward the more complete utilization of the available food resources.

The times of maturation of source rocks, similar to their times of deposition, were also quite uneven in geologic time (fig. 15). The major stage of maturation of Paleozoic source rocks was during the Hercynian orogeny, when thick molasses were deposited widely. The next main maturation stage on the global scale occurred during latest Cretaceous and Tertiary time in connection with the Alpine orogeny and deposition of thick molasse formations of this age.

The cumulative diagram in figure 16 summarizes the stages of deposition of source rocks, their maturation, and the entrapment of derived petroleum. Slightly more than a quarter of the world's effective source rocks (measured by the amounts of petroleum reserves generated by these rocks) were deposited by the end of Early Permian time. Almost all of the remaining threequarters were deposited since the beginning of the Late Jurassic. As could be expected, the line of effective source-rock deposition is mostly located above the line of trapped petroleum, reflecting the dominance of upwarddirected vertical migration. However, the relative positions of these lines are reversed at the base of the Upper Jurassic. This means that all effective source rocks 
deposited before the Late Jurassic could not have provided the amounts of oil and gas that are trapped in the pre-Upper Jurassic section. This relationship emphasizes the importance of the downward vertical migration for formation of oil and gas fields.

The line of maturation of effective source rocks is displaced toward younger ages compared with the line of their deposition. The vertical distance between the two lines shows the difference between the amounts of effective source rocks deposited and the amounts matured before a given geologic time (again measured in the quantities of generated petroleum reserves). The horizontal distance between the lines shows the average geologic time that elapsed between the deposition of a certain amount of effective source rocks and the time when the same amount of earlier deposited source rocks reached their maturity. The cumulative maturation line clearly demonstrates the general youthfulness of most of the discovered oil and gas. More than 80 percent of the world's oil and gas reserves were generated since Aptian time, almost 70 percent were generated since Coniacian time, and nearly half of the petroleum reserves were generated and trapped since the Oligocene. This line does not reach 100 percent because about 6 percent of the world's petroleum reserves consist of biogenic gas from still immature source rocks; the bulk of this gas occurs in northern West Siberia.
The chart additionally shows the amount of petroleum reserves sealed by evaporites-that is, salt and anhydrite. Evaporites seal more than 36 percent of the world's petroleum reserves despite their very small volume compared with the total volume of sedimentary rocks. Most of the oil and gas sealed by evaporites occur in Permian through Upper Jurassic and OligoceneMiocene sections. Such a large amount of petroleum controlled by evaporites emphasizes the importance of high-quality regional seals for the entrapment and preservation of oil and gas. Probably, permafrost may also be considered as a seal of high quality. However, only in the Cenomanian section of the northern West Siberian basin are permafrost seals known to control large reserves of gas.

Evaporite cap rocks are especially important for oil and gas accumulations in the pre-Upper Jurassic section. About half of the discovered oil and gas reserves in this section (mainly generated by Paleozoic source rocks) are sealed by salt and/or anhydrite primarily of Late Permian and Triassic age. These petroleum reserves are dominantly located on immobile cratons and "epicratons" (stabilized accreted zones), which have been less subject to destruction than their tectonically active margins. Evaporite cap rocks prevented the leakage of oil and gas from these early entrapped accumulations during long spans of geologic time. Post-Middle Jurassic

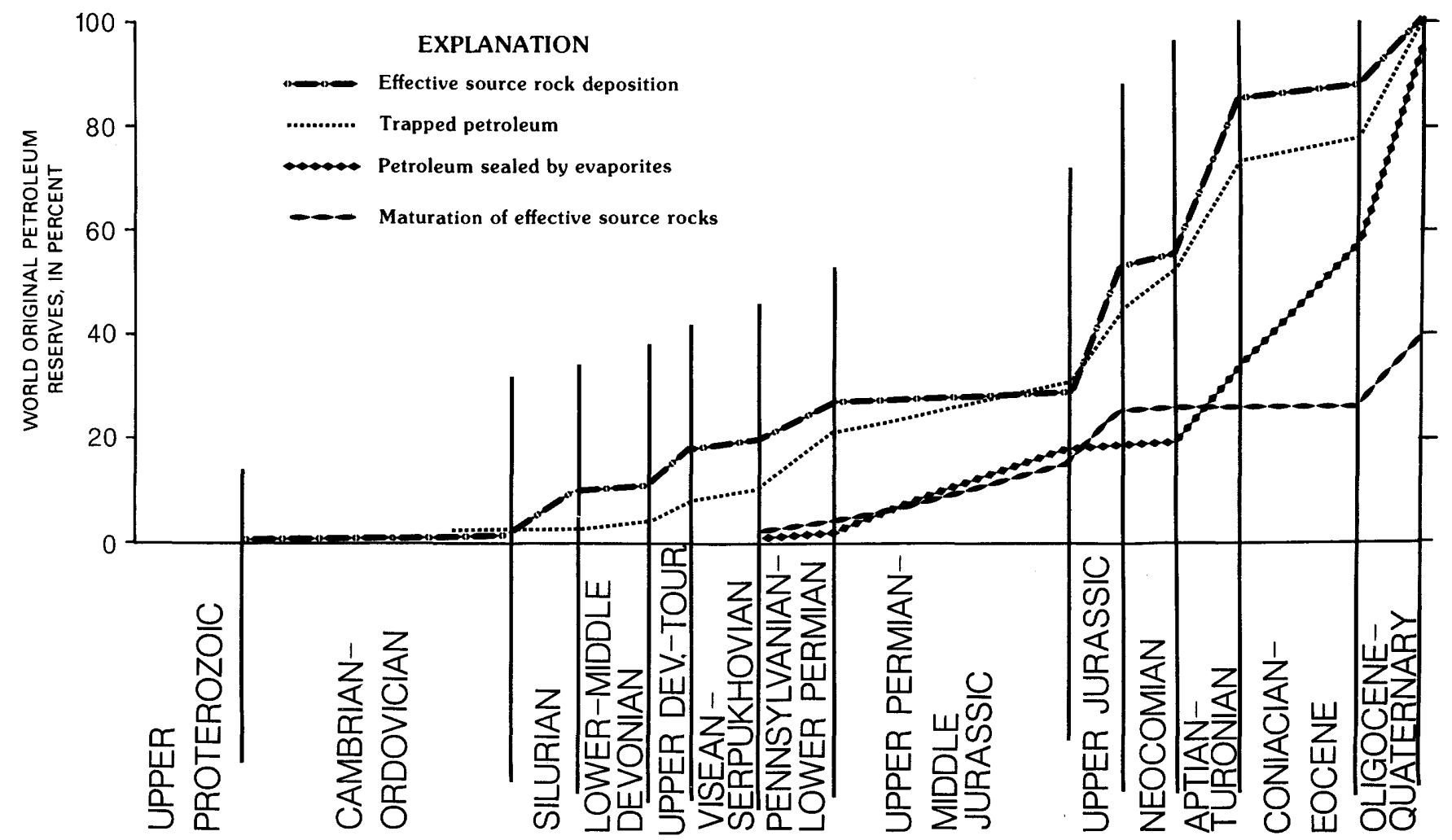

Figure 16. Cumulative chart of effective source-rock deposition, source-rock maturation, petroleum trapped in the stratigraphic succession, and petroleum sealed by evaporite rocks, in percent of world's original reserves of petroleum. 
evaporite seals are relatively less abundant; they control about one-third of petroleum reserves discovered in this section. These younger evaporite seals are present mainly in the Alpine foredeeps and adjoining forelands, that is, in tectonically unstable structures. Many of these cap rocks, as for example the Miocene Gach Saran Formation in the Zagros foredeep, will be destroyed in the near geologic future.

In conclusion, the authors hope that this study will help to improve understanding of the global distribution of source rocks and their connection with discovered petroleum. Further, we hope that the obtained results contribute to basin analysis and to the search for new reserves of oil and gas.

\section{ACKNOWLEDGMENTS}

We are grateful to all our colleagues at the World Energy Resource Program in the U.S. Geological Survey who helped much in understanding the geology and petroleum resources of many basins. C.D. Masters and T.D. Fouch critically reviewed the manuscript and made many helpful suggestions. We also acknowledge P.L. Martin for editing the manuscript and V.F. Ulmishek for drafting the maps and other illustrations.

\section{REFERENCES CITED}

Adler, F.J., 1971, Future petroleum provinces of the midcontinent, region 7, in Cram, I.H., ed., Future petroleum provinces of the United States-Their geology and potential: American Association of Petroleum Geologists Memoir 15, v. 2, p. 985-1120.

Akramkhodzhayev, A.M., and Egamberdyev, M.E., 1985, Otlozheniya khodzhaipakskoy svity verkhney yury-Vozmozhnyye sredneaziatskiye analogi bazhenitov [Rocks of the Upper Jurassic Khodzhaipak Suite-Possible central Asian analogs of bazhenites]: Geologiya Nefti i Gaza, 1985 , no. 2, p. 19-24.

Ala, M.A., 1982, Chronology of trap formation and migration of hydrocarbons in Zagros section of southwestern Iran: American Association of Petroleum Geologists Bulletin, v. 66 , no. 10 , p. $1535-1541$.

Ala, M.A., Kinghorn, R.R.F., and Rahman, M., 1980, Organic geochemistry and source rock characteristics of the Zagros petroleum province, southwest Iran: Journal of Petroleum Geology, v. 3, p. 61-89.

Aliyev, M.M., Vysotsky, V.I., Golenkova, N.P., and Timonin, L.S., 1979, Geologicheskoye stroyeniye i neftegazonosnost' Severnoy Afriki, Blizhnego i Srednego Vostoka [Geology and hydrocarbon potential of North Africa and the Near and Middle East]: Baku, U.S.S.R., Elm, 245 p.

Ali-Zade, A.A., Akhmedov, G.A., Aliyev, G.A., Pavlova, V.A., and Khatskevich, N.I., 1975, Otsenka nefteproizvodyaschikh svoystv mezo-kaynozoyskikh otlozheniy Azerbay- dzhana, [Assessment of oil-generative characteristics of Mesozoic-Cenozoic rocks of Azerbaijan]: Baku, U.S.S.R., Elm, 140 p.

al-Laboun, A.A., 1986, Stratigraphy and hydrocarbon potential of the Paleozoic succession in both Tabuk and Widyan basins, Arabia, in Halbouty, M.T., ed., Future petroleum provinces of the world: American Association of Petroleum Geologists Memoir 40, p. 373-397.

Alsharhan, A.S., 1987, Geology and reservoir characteristics of carbonate buildup in giant $\mathrm{Bu}$ Hasa oil field, Abu Dhabi, United Arab Emirates: American Association of Petroleum Geologists Bulletin, v. 71 , no. 10, p. 1304-1318.

Alsharhan, A.S., and Kendall, C.G.St.C., 1986, Precambrian to Jurassic rocks of Arabian Gulf and adjacent areasTheir facies, depositional setting, and hydrocarbon habitat: American Association of Petroleum Geologists Bulletin, v. 70, no. 8, p. 977-1002.

Andersson, A., Dahlman, B., Gee, D.G., and Snäll, S., 1985, The Scandinavian alum shales: Sveriges Geologiska Undersökning, Ser. Ca, Avhandlingar och Uppsatser $1 \mathrm{~A} 4$, no. 56, $50 \mathrm{p}$.

Arkhipov, A. Ya., D'yakonov, A.I., Bolotov, Ye.N., and Ruchnov, V.I., 1979, Zonal'nost' neftegazoobrazovaniya i neftegazonakopleniya $\mathbf{v}$ mezozoyskikh otlozheniyakh Zapadnogo Predkavkaz'ya [Zonality of oil and gas generation and accumulation in Mesozoic rocks of western Ciscaucasia], in Vassoyevich, N.B., and Timofeyev, P.P., eds., Neftematerinskiye svity i printsipy ikh diagnostiki: Moscow, Nauka, p. 220-226.

ASCOPE, 1981, Tertiary sedimentary basins of the Gulf of Thailand and South China Sea-Stratigraphy, structure, and hydrocarbon occurrences: Jakarta, Indonesia, Association of Southeast Asian Nations Council on Petroleum (ASCOPE), $72 \mathrm{p}$.

Ashirov, K.B., Danilov, V.I., Isayev, V.N., and Belerova, V.A., 1981 , Geokhimicheskoye issledovaniye uglevodorodnogo sostava legkikh fraktsiy neftey i bitumoidov vmeshchayushchikh porod paleozoya Srednego Povolzh'ya [Geochemical study of the hydrocarbon composition of light oil fractions and bitumens of Paleozoic host rocks of the central Volga region], in Sidorenko, A.V., and Yeremenko, N.A., eds., Organicheskaya geokhimiya neftey, gazov i organicheskogo veshchestva dokembriya: Moscow, Nauka, p. 114-118.

Aubouin, Jean, Debelmas, Jacques, and Latreille, Michel, eds., 1980, Geology des chaines alpines issues de la Tethysm; Geology of the Alpine chains born of the Tethys: International Geological Congress, 26th, Paris, July 7-17, 1980, colloquium C5; [France] Bureau de Recherches Géologiques et Minières, Mémoires, no. 115,355 p.

Ayres, M.G., Bilal, M., Jones, R.W., Slentz, L.W., Tartir, M., and Wilson, A.O., 1982, Hydrocarbon habitat in main producing areas, Saudi Arabia: American Association of Petroleum Geologists Bulletin, v. 66, no. 1, p. 1-9.

Baird, R.A., 1986, Maturation and source rock evaluation of Kimmeridge Clay, Norwegian North Sea: American Association of Petroleum Geologists Bulletin, v. 70, no. 1, p. 1-11. 
Bakhturov, S.F., 1985, Bituminoznyye karbonatno-slantsevyye formatsii Vostochnoy Sibiri [Bituminous carbonate and shale formations of East Siberia]: Trudy Instituta Geologii i Geofiziki (Novosibirsk), no. 617, 125 p.

Balducchi, A., and Pommier, G., 1970, Cambrian oil field of Hassi Messaoud, Algeria, in Halbouty, M.T., ed., Geology of giant petroleum fields: American Association of Petroleum Geologists Memoir 14, p. 477-488.

Bally, A.W., and Snelson, S., 1980, Realm of subsidence, in Miall, A.D., ed., Facts and principles of world petroleum occurrence: Canadian Society of Petroleum Geologists Memoir 6, p. 9-94.

Barrows, M.H., and Cluff, R.M., 1984, New Albany Shale Group (Devonian-Mississippian) source rocks and hydrocarbon generation in the Illinois basin, in Demaison, Gerard, and Murris, R.J., eds., Petroleum geochemistry and basin evaluation: American Association of Petroleum Geologists Memoir 35, p. 111-138.

Bates, Marston, 1960, Ecology and evolution, in Tax, Sol, ed., Evolution after Darwin, v. 1, The evolution of life: Chicago, The University of Chicago Press, p. 547-568.

Bazhenova, O.K., Burlin, Yu. K., and Karnushina, E.E., 1986, Usloviya nefteobrazovaniya $v$ fanerozoyskikh silitsitakh [Conditions of oil generation in Phanerozoic siliciliths], in Yeremenko, N.A., Neruchev, S.G., and Sokolov, B.A., eds., Evolutsiya neftegazoobrazovaniya $\mathbf{v}$ istorii Zemli: Moscow, Nauka, p. 95-102.

Bazhenova, T.K., 1986, Biotsenoticheskiye aspekty nefteobrazovaniya $\mathrm{v}$ otlozheniyakh paleozoya i verkhnego proterozoya (na primere Sibirskoy platformy) [Biocenotic aspects of oil generation in Paleozoic and upper Proterozoic rocks (on the example of the Siberian craton)], in Yeremenko, N.A., Neruchev, S.G., and Sokolov, B.A., eds., Evolutsiya neftegazoobrazovaniya $v$ istorii Zemli: Moscow, Nauka, p. 32-37.

Bergstrom, R.E., Shimp, N.F., and Cluff, R.M., 1980, Geologic and geochemical studies of the New Albany Shale Group (Devonian-Mississippian) in Illinois: ChampaignUrbana, Ill., Illinois State Geological Survey, 183 p.

Berlin, Yu. M., and Ulmishek, G.F., 1978, Litologicheskiy sostav, paleogeograficheskie i paleogeomorfologicheskiye usloviya nakopleniya kumskogo i maykopskogo kompleksov otlozheniy Kaspiyskogo regiona [Lithology, paleogeographic and paleomorphic conditions of deposition of the Kuma and Maykop sections of the Caspian region], in Geodekyan, A.A., ed., Protsessy neftgazoobrazovaniya $\mathbf{v}$ akvatorii Kaspiyskogo morya: Moscow, P.P. Shirshov Institute of Oceanology, p. 17-27.

Berry, W.B.N., 1962, Graptolite occurrence and ecology: Journal of Paleontology, v. 36, no. 2, p. 285-293.

1987, Phylum Hemichordata (including Graptolithina), in Boardman, R.S., Cheetham, A.H., and Rowell, A.J., eds., Fossil invertebrates: Palo Alto, Calif., Blackwell Scientific Publications, p. 612-635.

Bird, K.J., and Magoon, L.B., eds., 1987, Petroleum geology of the northern part of the Arctic National Wildlife Refuge, northeastern Alaska: U.S. Geological Survey Bulletin 1778,329 p.
Blaser, Rudolf, and White, Christopher, 1984, Source-rock and carbonization study, Maracaibo basin, Venezuela, in Demaison, Gerard, and Murris, R.J., eds., Petroleum geochemistry and basin evaluation: American Association of Petroleum Geologists Memoir 35, p. 229-252.

Bois, C., Bouche, P., and Pelet, R., 1982, Global geologic history and distribution of hydrocarbon reserves: American Association of Petroleum Geologists Bulletin, v. 66 , no. 9, p. 1248-1270.

Broadhead, R.F., Kepferle, R.C., and Potter, P.E., 1982, Stratigraphic and sedimentologic controls of gas in shale-Example from Upper Devonian of northern Ohio: American Association of Petroleum Geologists Bulletin, v. 66 , no. 1, p. $10-27$.

Budyko, M.I., Ronov, A.B., and Yanshin, A.L., 1987, History of the Earth's atmosphere: Berlin, Springer-Verlag, 139 p.

Bülow, Kurd von, 1959, Die Verflechtung von Erd- und Lebensgeschichte, in Die Entwicklungsgeschichte der Erdc: Leipzig, Kosmograph Verlag, p. 438-451.

Burlakov, I.A., Khadisova, R.A., Keligrekhashvili, L.A., and Leshchinskaya, T.B., 1987, Geokhimicheskaya kharakteristika glinistykh neftenosnykh otlozheniy oligotsena Vostochnogo Predkavkaz'aya [Geochemical characteristics of Oligocene oil-producing shales in eastern Ciscaucasia]: Geologiya Nefti i Gaza, 1987, no. 4, p. $40-43$.

Bustin, R.M., 1988, Sedimentology and characteristics of dispersed organic matter in Tertiary Niger Delta-Origin of source rocks in a deltaic environment: American Association of Petroleum Geologists Bulletin, v. 72, no. 3, p. 277-298.

Buzas, M.A., 1987, Smaller Foraminifera, in Boardman, R.S., Cheetham, A.H., and Rowell, A.J., eds., Fossil invertebrates: Palo Alto, Calif., Blackwell Scientific Publications, p. 72-81.

Byers, C.W., 1977, Biofacies patterns in euxinic basins-A general model, in Cook, H.E., and Enos, Paul, Deepwater carbonate environments: Society of Economic Paleontologists and Mineralogists Special Publication no. 25, p. 5-17.

Campbell, J.A., Mankin, C.J., Schwarzkopf, A.B., and Raymer, J.H., 1988, Habitat of petroleum in Permian rocks of the midcontinent region, in Morgan, W.A., and Babcock, J.A., eds., Permian rocks of the midcontinent: Midcontinent [Section], Society of Economic Paleontologists and Mineralogists, Special Publication no. 1, p. 13-35. Available from Kansas Geological Survey, 1930 Constant Ave., University of Kansas, Lawrence, KS 66046.

Cannon, J.L., 1971, Petroleum potential of western Montana and northern Idaho, in Cram, I.H., ed., Future petroleum provinces of the United States-Their geology and potential: American Association of Petroleum Geologists Memoir 15, v. 1, p. 547-568.

Carman, G.J., and Hardwick, Peter, 1983, Geology and regional setting of the Kuparuk oil field, Alaska: American Association of Petroleum Geologists Bulletin, v. 67, no. 6, p. 1014-1031. 
Chakhmakhchev, V.A., Vinogradova, T.L., Razumova, Ye.R., Yakubson, Z.V., Kukushkina, Z.P., and Doshko, A.S., 1987, Geokhimicheskaya otsenka neftegazonosnosti yurskikh podsolevykh otlozheniy Vostochno-Kubanskoy vpadiny [Geochemical assessment of petroleum potential of Jurassic subsalt rocks of the East Kuban basin]: Geologiya Nefti i Gaza, 1987, no. 12, p. 46-50.

Chaykovskaya, E.V., and Volik, T.V., 1986, K otsenke neftematerinskogo potentsiala domanikoidnykh otlozheniy devona yuzhnoy chasti Pripyatskogo NGB [Assessment of source potential of Domanik-type Devonian rocks of the southern Pripyat basin], in Trofimuk, A.A., Kontorovich, A.E., and Marasanova, N.V., eds., Sovremennye geokhimicheskiye metody diagnostiki neftematerinskikh otlozheniy: Moscow, Nauka, p. 136-141.

Chepak, G.N., Shaposhnikov, V.M., Naryzhnyi, P.S., Markov, V.F., Goshokov, Kh.I., and Markov, A.N., 1983, Osobennosti neftenosnosti glinistoy tolshchi oligotsena Vostochnogo Predkavkaz'ya [Oil productivity of Oligocene shales in eastern Ciscaucasia]: Geologiya Nefti i Gaza, 1983, no. 8, p. $36-40$.

Cherskiy, N.V., ed., 1986, Istoriya neftegazoobrazovaniya i neftegazonakopleniya na vostoke Sibirskoy platformy [History of oil and gas generation and accumulation on the eastern Siberian craton]: Moscow, Nauka, $166 \mathrm{p}$.

Claypool, G.E., Love, A.H., and Maughan, E.K., 1978, Organic geochemistry, incipient metamorphism, and oil generation in black shale members of Phosphoria Formation, western interior United States: American Association of Petroleum Geologists Bulletin, v. 62, p. 98-120.

Clifford, A.C., 1986, African oil-past, present, and future, in Halbouty, M.T., ed., Future petroleum provinces of the world: American Association of Petroleum Geologists Memoir 40, p. 339-372.

Combaz, A., and de Matheral, M., 1978, Organic sedimentation and genesis of petroleum in Mahakam Delta, Borneo: American Association of Petroleum Geologists Bulletin, v. 62, no. 9, p. 1684-1695.

Cooper, B.S., and Barnard, P.C., 1984, Source rocks and oils of the central and northern North Sea, in Demaison, Gerard, and Murris, R.J., eds., Petroleum geochemistry and basin evaluation: American Association of Petroleum Geologists Memoir 35, p. 303-314.

Crain, W.E., Mero, W.E., and Patterson, Donald, 1985, Geology of the Point Arguello discovery: American Association of Petroleum Geologists Bulletin, v. 69, no. 4, p. 537-545.

Crimes, T.P., and Anderson, M.M., 1985, Trace fossils from late Precambrian-Early Cambrian strata of southeastern Newfoundland (Canada)-Temporal and environmental implications: Journal of Paleontology, v. 59, no. 2, p. 310-343.

Curtis, D.M., 1980, Paleotectonic settings for petroleum source rocks: Revue de 1,'Institut Français du Pétrole, v. 35, no. 2, p. 215-222.
Davitashvili, L.Sh., 1971, Evolyutsiya usloviy nakopleniya goryuchikh iskopayemykh $\mathrm{v}$ svyazi s razvitiyem organicheskogo mira [Conditions of genesis of caustobioliths in relation to development of the organic world]: Moscow, Nauka, 296 p.

Dean, W.E., and Fouch, T.D., 1983, Lacustrine environment, in Scholle, P.A., Bebout, D.G., and Moore, C.H., eds., Carbonate depositional environments: American Association of Petroleum Geologists Memoir 33, p. 98-130.

Degens, E.T., and Mopper, Kenneth, 1976, Factors controlling the distribution and early diagenesis of organic matter in marine sediments, in Riley, J.P., ed., Chemical oceanography, v. 6: London, Academic Press, p. 59-113.

Demaison, Gerard, 1984, The generative basin concept, in Demaison, G., and Murris, R.J., eds., Petroleum geochemistry and basin evaluation: American Association of Petroleum Geologists Memoir 35, p. 1-14.

Demaison, G.J., and Moore, G.T., 1980, Anoxic environments and oil source bed genesis: American Association of Petroleum Geologists Bulletin, v. 64, no. 8, p. 1179-1209.

Dolton, G.L. Carlson, K.H., Charpentier, R.R., Coury, A.B., Crovelli, R.A., Frezon, S.E., Khan, A.S., Lister, J.H., McMullin, R.H., Pike, R.S., Powers, R.B., Scott, E.W., and Varnes, K.L., 1981, Estimates of undiscovered recoverable conventional resources of oil and gas in the United States: U.S. Geological Survey Circular 860, 87 p.

Dow, W.G., 1978, Petroleum source beds on continental slopes and rises: American Association of Petroleum Geologists Bulletin, v. 62, no. 9, p. 1584-1606.

Droser, M.L., and Bottjer, D.J., 1988, Trends in depth and extent of bioturbation in Cambrian carbonate marine environments, western United States: Geology, v. 16, no. 3, p. 233-236.

Dunnington, H.V., 1958, Generation, migration, accumulation, and dissipation of oil in northern Iraq, in Weeks, L.G., ed., Habitat of oil: Tulsa, Okla., American Association of Petroleum Geologists, p. 1194-1251.

1967, Stratigraphic distribution of oil fields in the Iraq-Iran-Arabia basin: Institute of Petroleum Journal, $v$. 53 , p. 129-153.

Ejedawe, J.E., Coker, S.J.L., Lambert-Aikhionbare, D.O., Alofe, K.B., and Adoh, F.O., 1984, Evolution of oilgenerative window and oil and gas occurrence in Tertiary Niger Delta basin: American Association of Petroleum Geologists Bulletin, v. 68, no. 11, p. 1744-1751.

Erdtmann, B.D., 1982, Palaeobiogeography and environments of planktic dictyonemid graptolites during the earliest Ordovician, in Bassett, M.G., and Dean, W.T., eds., The Cambrian-Ordovician boundary-Sections, fossil distribution, and correlations: Cardiff, United Kingdom, National Museum of Wales, Geological Series No. 3, p. 9-27.

Eremenko, N.A., Neruchev, S.G., Sokolov, B.A., and Bazhenova, O.K., eds., 1986, Evolyutsiya neftegazoobrazovaniya $\mathrm{v}$ istorii Zemli [Evolution of oil and gas generation in the history of the Earth]: Moscow, Nauka, 222 p.

Exxon Corporation, 1982, How much oil and gas: [New York] Public Affairs Department, Exxon Background Series, $17 \mathrm{p}$. 
Fayzullina, Ye.M., Kaplan, Z.G., Zelichenko, I.A., and Skubelina, L.S., 1986, Novyye dannye po issledovaniyu NOV porod domanikovogo tipa metodami IKS i rentgenostrukturnogo analiza [New data from study of insoluble organic matter of Domanik-type rocks by infrared spectrometry and X-ray analysis]: Geologiya Nefti i Gaza, 1986, no. 4, p. 54-59.

Fedonkin, M.A., 1987, Besskeletnaya fauna venda i eyo mesto $v$ evolutsii metazoa [Soft-bodied Vendian fauna and its place in the evolution of Metazoa]: Akademiya Nauk SSSR, Trudy Paleontologicheskogo Instituta, v. 226, Moscow, Nauka, 174 p.

Fei Qi and Wang Xie-Pei, 1984, Significant role of structural fractures in Renqiu buried-hill oil field in eastern China: American Association of Petroleum Geologists Bulletin, v. 68 , no. 8 , p. 971-982.

Fisunenko, O.P., 1964, O dvukh srednekamennougolnykh rastitelnykh formatsiyakh i etapakh ikh razvitiya [Two Middle Carboniferous plant groups and stages of their development], in Voprosy zakonomernostey i form razvitiya organicheskogo mira: Moscow, Nedra, p. 148-158.

Fomina, A.S., 1959, K voprosu o proiskhozhdenii pribaltiyskikh kukersitnykh goryuchikh slantsev [Origin of Baltic kukersitic oil shales], in Karavaev, N.M., and Titov, N.G., eds., Genezis tverdykh goryuchikh iskopaemykh: Moscow, Akademiya Nauk SSSR, p. 77-91.

Fomkin, K.V., ed., 1985, Geokhimicheskiye osobennosti neftegazonosnosti Prikaspiyskoy vpadiny [Geochemistry of oil- and gas-productive Peri-Caspian depression]: Trudy Vsesoyuznyy Nauchno-Issledovatel'skiy Geologorazvedochnyy Neftyanoy Institut (VNIGNI), no. 251, 265 p.

Forman, D.J., Powell, T.G., and Robertson, C.S., 1988, Australia's petroleum potential, in Petroleum in Australia-The first century: APEA Journal, v. 28, p. 48-90.

Gall, J.-C., 1983, Ancient sedimentary environments and the habitats of living organisms: Berlin-Heidelberg, Springer-Verlag, 219 p.

Gardner, W.C., and Bray, E.E., 1984, Oils and source rocks of Niagaran reefs (Silurian) in the Michigan basin, in Palacas, J.G., ed., Petroleum geochemistry and source rock potential of carbonate rocks: American Association of Petroleum Geologists Studies in Geology, no. 18, p. 33-44.

Gavrish, V.K., ed., 1985, Neftegazonosnye provintsii Ukrainy [Petroleum provinces of the Ukraine]: Kiev, U.S.S.R., Naukova Dumka, 172 p.

Geodekyan, A.A., Volkolakov, F.K., Dubovskoy, I.T., Lapinskas, P.P., Lashkov, E.M., Sakalauskas, K.A., Ulmishek, G.F., Kharin, G.S., and Khubldikov, A.I., 1976, Geologicheskoye stroyeniye i perspectivy neftegazonosnosti tsentralnoy Baltiki [Geologic framework and petroleum potential of the central Baltic region]: Moscow, Nauka, $110 \mathrm{p}$.

Glaessner, M.F., 1966, Precambrian paleontology: EarthScience Reviews, v. 1, p. 29-50.

1976, Early Phanerozoic annelid worms and their geological and biological significance: Journal of the Geological Society (London), v. 132, p. 259-275.
Goff, J.C., 1984, Hydrocarbon generation and migration from Jurassic source rocks in the East Shetland basin and Viking graben of the northern North Sea, in Demaison, Gerard, and Murris, R.J., eds., Petroleum geochemistry and basin evaluation: American Association of Petroleum Geologists Memoir 35, p. 273-301.

Gordon, T.L., 1985, Talang Akar coals-Ardjuna subbasin oil source: Indonesian Petroleum Association Proceedings, 14th Annual Convention, October 1985, p. 91-120.

Grace, J.D., and Hart, G.F., 1986, Giant gas fields of northern West Siberia: American Association of Petroleum Geologists Bulletin, v. 70, no. 7, p. 830-852.

Graham, S.A., and Williams, L.A., 1985, Tectonic, depositional and diagenetic history of Monterey Formation (Miocene), central San Joaquin basin, California: American Association of Petroleum Geologists Bulletin, v. 69, no. 3, p. $385-411$.

Grunau, H.R., 1983, Abundance of source rocks for oil and gas worldwide: Journal of Petroleum Geology, v. 6, no. 1, p. 39-54.

Guseva, A.N., Leyfman, I.Ye., and Sokolov, B.A., 1981, Geokhimicheskiye predposylki vozmozhnosti nefteobrazovaniya $v$ dokembriyskikh porodakh [Geochemical prerequisites for the possibility of oil generation in Precambrian rocks], in Sidorenko, A.V., and Yeremenko, N.A., eds., Organicheskaya geokhimiya neftey, gazov i organicheskogo veschestva dokembriya: Moscow, Nauka, p. 221-226.

Gutschick, R.C., 1987, Devonian shelf-basin, Michigan basin, Alpena, Michigan, in Biggs, D.L., ed., North-Central Section of the Geological Society of America: Boulder, Colo., Geological Society of America, Centennial Field Guide, v. 3, p. 297-302.

Hartman, J.K., and Woodard, L.R., 1971, Future petroleum resources in post-Mississippian strata of north, central, and west Texas and eastern New Mexico, in Cram, I.H., ed., Future petroleum provinces of the United StatesTheir geology and potential: American Association of Petroleum Geologists Memoir 15, v. 1, p. 752-800.

Hedberg, H.D., 1950, Geology of the Eastern Venezuela basin: Geological Society of America Bulletin, v. 61, p. 1173-1216.

Hill, C.S., 1971, Future petroleum resources in prePennsylvanian rocks of north, central, and west Texas and eastern New Mexico, in Cram, 1.H., ed., Future petroleum provinces of the United States-Their geology and potential: American Association of Petroleum Geologists Memoir 15, v. 1, p. 738-751.

Hofmann, H.J., and Schopf, J.W., 1983, Early Proterozoic microfossils, in Schopf, J.W., ed., Earth's earliest biosphere-Its origin and evolution: Princeton, N.J., Princeton University Press, p. 321-360.

Holcomb, C.W., 1971, Hydrocarbon potential of Gulf Series of western Gulf basin, in Cram, I.H., ed., Future petroleum provinces of the United States-Their geology and potential: American Association of Petroleum Geologists Memoir 15, v. 2, p. 887-900. 
Huang Difan, Shang Huiyun, and Li Jinchao, 1984, Advances in theoretical research on continental oil generation in China: Beijing Petroleum Geology Symposium, September 1984, Beijing, China, Preprint, 38 p.

Huang Jizhong, 1984, The occurrence of oil and gas in the Yangxin limestone series, Sichuan basin: Acta Petrolei Sinica, v. 5, no. 1, p. 7-18.

Hubert, J.F., Suchecki, R.K., and Callahan, R.K., 1977, The Cow Head breccia-Sedimentology of the CambroOrdovician continental margin, Newfoundland, in Cook, H.E., and Enos, Paul, eds., Deep-water carbonate environments: Society of Economic Paleontologists and Mineralogists Special Publication no. 25, p. 125-154.

Hughes, N.F., 1973, Mesozoic and Tertiary distributions, and problems of land-plant evolution, in Hughes, N.F., ed., Organisms and continents through time: Special Papers in Palaeontology, no. 12, p. 189-198.

Hull, C.E., and Warman, H.R., 1970, Asmari oil fields of Iran, in Halbouty, M.T., ed., Geology of giant petroleum fields: American Association of Petroleum Geologists Memoir 14, p. 428-437.

Hunt, J.M., 1979, Petroleum geochemistry and geology: San Francisco, W.H. Freeman and Co., 617 p.

written commun., 1988, "Petroleum expulsion from abnormally pressured fluid compartments," presented at the American Association of Petroleum Geologists Research Conference on Petroleum Potential of Sedimentary Basins, Leesburg, Virginia, April 26-29.

Il'inskaya, V.V., and Kulayeva, T.P., 1979, Osobennosti sostava organicheskogo veshchestva paleozoyskikh porod Dneprovsko-Donetskoy vpadiny i kharakter neftegazoobrazovaniya [The characteristic composition of organic matter in Paleozoic rocks of the Dnieper-Donets basin and the nature of its oil and gas generation], in Vassoyevich, N.B., and Timofeyev, P.P., eds., Neftematerinskiye svity i printsipy ikh diagnostiki: Moscow, Nauka, p. 155-160.

Ivanhoe, L.F., 1985, Potential of world's significant oil provinces: Oil and Gas Journal, v. 83, no. 46 (Nov. 18), p. 164-168.

Ivantsova, V.V., 1969, Novye dannye o geneticheskoy svyazi porod i neftey mezozoyskikh otlozheniy Zapadnoy Sibiri [New data on the genetic relationship between rocks and oils of the Mesozoic section of West Siberia], in Geokhimicheskiy sbornik no. 10: Trudy Vsesoyuznogo Neftyanogo Nauchno-Issledovatel'skogo GeologoRazvedochnogo Instituta (VNIGRI), no. 279, p. 133-142.

Jacobson, S.R., Hatch, J.R., Teerman, S.C., and Askin, R.A., 1988, Middle Ordovician organic matter assemblages and their effect on Ordovician-derived oils: American Association of Petroleum Geologists Bulletin, v. 72, no. 9, p. $1090-1100$.

James, G.A., and Wynd, J.G., 1965, Stratigraphic nomenclature of Iranian Oil Consortium Agreement Area: American Association of Petroleum Geologists Bulletin, v. 49, no. 12, p. 2182-2245.
Jones, T.S., and Smith, H.M., 1965, Relationships of oil composition and stratigraphy in the Permian basin of West Texas and New Mexico, in Young, Addison, and Galley, J.E., eds., Fluids in subsurface environments: American Association of Petroleum Geologists Memoir 4, p. 101-224.

Kantsler, A.J., Prudence, T.J.C., Cook, A.C., and Zwigulis, M., 1984, Hydrocarbon habitat of the Cooper/Eromanga basin, Australia, in Demaison, Gerard, and Murris, R.J., eds., Petroleum geochemistry and basin evaluation: American Association of Petroleum Geologists Memoir 35, p. 373-390.

Kholief, M.M., and Barakat, M.A., 1986, New evidence for a petroleum source rock in a Miocene evaporite sequence, Gulf of Suez, Egypt: Journal of Petroleum Geology, v. 9, no. 2 , p. $217-226$.

Kingston, D.R., Dishroon, C.P., and Williams, P.A., 1983, Hydrocarbon plays and global basin classification: American Association of Petroleum Geologists Bulletin, v. 67 , p. $2194-2198$.

Kingston, J., 1979, Oil and gas generation, migration, and accumulation in North Sumatra basin: Southeast Asia Petroleum Exploration Society, Proceedings, v. 4, 1977-78, p. 158-182.

Klemme, H.D., 1971, Giants, supergiants and their relation to basin types: Oil and Gas Journal, v. 69, no. 9, p. 85-90; no. 10 , p. $103-110$; no. 11 , p. 96-100.

1980, Petroleum basins-Classifications and characteristics: Journal of Petroleum Geology, v. 3, no. 2, p. 187-207.

1983, Field size distribution related to basin characteristics: Oil and Gas Journal, v. 81, no. 52 (Dec. 26), p. 168-176.

1984, Oil and gas maps and sections of the ArabianIranian basin: U.S. Geological Survey Open-File Report 84-0353, 13 sheets.

Klubov, B.A., 1983, Prirodnye bitumy severa [Natural bitumens of the Arctic]: Moscow, Nauka, 205 p.

Kontorovich, A.E., Modelevskiy, M.S., Trofimuk, A.A., Burshteyn, L.M., Gurevich, G.S., and Danil'chenko, L.A., 1986, Vozrast osadochnykh basseynov i yego vliyaniye na resursy uglevodorodov [Age of sedimentary basins and its effect on hydrocarbon resources]: Sovetskaya Geologiya, 1986, no. 10, p. 12-18.

Kontorovich, A.E., Nesterov, I.I., Salmanov, F.K., Surkov, V.S., Trofimuk, A.A., and Erv'ye, Yu.G., 1975, Geologiya nefti i gaza Zapadnoy Sibiri [Geology of oil and gas of West Siberia]: Moscow, Nedra, 679 p.

Koop, W.J., and Stoneley, R., 1982, Subsidence history of the Middle East Zagros Basin, Permian to Recent, in Kent, Peter, Botts, M.H.P., McKenzie, D.P., and Williams, C.A., eds., Evolution of sedimentary basins: Philosophical Transactions of the Royal Society of London, ser. A, v. 305, no. 1489, p. 149-168.

Korchagina, Yu.I., and Zeynalova, K.S., 1986, Neftegazoprodutsiruyushchiye svoystva glubokopogruzhennykh gorizontov Prikurinskoy vpadiny [Petroleum-generating characteristics of deeply buried rocks of the Kura depression]: Geologiya Nefti i Gaza, no. 12, p. 41-45. 
Kortsenshteyn, V.N., 1970, O vliyanii periodicheskikh oledeneniy na formirovaniye unikal'nykh gazovykh mestorozhdeniy severa Tyumenskoy oblasti [Effect of periodic glaciations on the formation of enormously large gas fields in the northern part of the Tyumen Oblast]: Akademiya Nauk SSSR, Doklady, v. 191, p. 1366-1369.

Kozlowski, Roman, 1966, On the structure and relationships of graptolites: Journal of Paleontology, v. 40, no. 3,p. 489-501.

Krause, Hans, 1988, (Intevep, PDV s.a., Venezuela) Poster session at the American Association of Petroleum Geologists Research Conference, Petroleum potential of sedimentary basins-methods, techniques, and approaches: Leesburg, Virginia, April 26-29.

Krylov, N.A., 1979, Geologicheskiye kriterii vydeleniya neftegazoproizvodyashikh formatsiy (na.primere epipaleozoyskikh plit yuga SSSR) [Geologic criteria for separating oil- and gas-producing formations (for example, of the post-Paleozoic platform of the southern U.S.S.R.)], in Vassoyevich, N.B., and Timofeyev, P.P., eds., Neftematerinskiye svity i printsipy ikh diagnostiki: Moscow, Nauka, p. 143-148.

Krylov, N.A., and Nekhrikova, N.I., 1987, Neftegazonosnost Prikaspiyskoy vpadiny i sopredelnykh rayonov [Petroleum potential of the Peri-Caspian depression and adjacent areas]: Moscow, Nauka, 192 p.

Kulikov, P.K, 1979, Strukturnyye etazhi Zapadno-Sibirskoy plity [Structural stages of the West Siberian platform], in Muratov, M.V., and others, eds., Tektonika territorii SSSR: Moscow, Nauka, p. 128-140.

Ladwein, H.W., 1988, Organic geochemistry of Vienna basinModel for hydrocarbon generation in overthrust belts: American Association of Petroleum Geologists Bulletin, v. 72, no. 5, p. 586-599.

Lagutenkova, N.S., and Chepikova, I.K., 1982, Verkhnedokembriyskiye otlozheniya Volgo-Ural'skoy oblasti i perspektivy ikh neftegazonosnosti [Upper Precambrian rocks of the Volga-Ural region and their petroleum potential]: Moscow, Nauka, 111 p.

Landes, K.K., 1970, Petroleum geology of the United States: New York, John Wiley and Sons, 571 p.

Lao Qiuyuan and Gao Wenxue, 1984, The characteristics of Cenozoic sedimentary basins in the North China platform: Sedimentary Geology, v. 40, p. 89-103.

Lehner, P., and De Ruiter, P.A.C., 1977, Structural history of Atlantic margin of Africa: American Association of Petroleum Geologists Bulletin, v. 61, no. 7, p. 961-981.

Levorsen, A.I., and Berry, F.A.F., 1967, Geology of petroleum (2d ed.): San Francisco and London, W.H. Freeman and Co., 724 p.

Li, A.B., Vlasov, V.I., Paragul'gov, Kh.Kh., Filip'yev, G.P., Chimbulatov, M.A., and Shakhabayev, R.S., 1982, Tektonicheskoye razvitiye $\mathrm{i}$ perspektivy neftegazonosnosti Chu-Sarysuyskoy depressii [Tectonic development and hydrocarbon potential of the Chu-Sarysu depression]: Alma-Ata, U.S.S.R., Nauka, 159 p.
Li Chunju, Zhu Shuian, and Zhu Shaobi, 1984, Sedimentary systems and oil-bearing features of the small intermontane rift lake basin of Biyang: Beijing Petroleum Geology Symposium, September 1984, Beijing, China, Preprint, 18 p.

Li Desheng, Du Yonglin, and Hu Guohong, 1984, Petroleum geological characteristics of Langfang-Guan basin, Beijing-Tienjing region: Beijing Petroleum Geology Symposium, September 1984, Beijing, China, Preprint, $25 \mathrm{p}$.

$\mathrm{Li}$ Xuehui and $\mathrm{Li}$ Tiesheng, [1984], A discussion on the favorable oil- and gas-bearing facies zones of the Carboniferous and Permian Systems in South China: International Symposium on Petroleum Geology, Beijing, China, 12 p.

Lin Longdong, 1984, The discovery of nappe-screened oil pool and the prospects of the Karamay oil field: Oil and Gas Geology, v. 5, no. 1, p. 1-10.

Lindsay, J.F., 1987, Sequence stratigraphy and depositionai controls in Late Proterozoic-Early Cambrian sediments of Amadeus basin, central Australia: American Association of Petroleum Geologists Bulletin, v. 71, no. 11, p. 1387-1403.

Magloire, P.R., 1970, Triassic gas field of Hassi er R'Mel, Algeria, in Halbouty, M.T., ed., Geology of giant petroleum fields: American Association of Petroleum Geologists Memoir 14, p. 489-501.

Maksimov, S.P., Kleschev, K.A., and Shein, V.S., eds., 1986, Geologiya i geodinamika neftegazonosnykh territoriy yuga SSSR [Geology and geodynamics of the hydrocarbon producing regions of the southern U.S.S.R.]: Moscow, Nedra, 232 p.

Maksimov, S.P., Pankina, R.G., and Smakhtina, A.M., 1987, Usloviya formirovaniya uglevodorodnykh skopleniy $v$ mezozoyskikh otlozheniyakh Amudar'inskoy gazoneftyanoy provintsii [Conditions of formation of hydrocarbon accumulations in Mesozoic rocks of the Amu-Darya petroleum province]: Geologiya Nefti i Gaza, 1987, no. 5, p. 20-27.

Masters, C.D., Attanasi, E.D., Dietzman, W.D., Meyer, R.F., Mitchell, R.W., and Root, D.H., 1987, World resources of crude oil, natural gas, natural bitumen, and shale oil: World Petroleum Congress, 12th, Houston, 1987, Preprint, 27 p.

McCollough, Chuck, and Padfield, Earl, 1985, Petroleum geology of Colombia's Llano basin-A summary: Oil and Gas Journal, v. 83, no. 15 (April 15), p. 82-96.

McCollum, L.B., 1988, A shallow epeiric sea interpretation for an offshore Middle Devonian black shale facies in eastern North America, in McMillan, N.J., Embry, A.F., and Glass, D.J., eds., Devonian of the world, Volume II-Sedimentation: Calgary, Alberta, Canadian Society of Petroleum Geologists, p. 347-355.

Meissner, F.F., 1984, Petroleum geology of the Bakken Formation, Williston basin, North Dakota and Montana, in Demaison, Gerard, and Murris, R.J., eds., Petroleum geochemistry and basin evaluation: American Association of Petroleum Geologists Memoir 35, p. 159-180. 
Meyen, S.V., 1987, Fundamentals of paleobotany: London, New York, Chapman and Hall, 432 p.

Michelson, J.E., 1976, Miocene deltaic oil habitat, Trinidad: American Association of Petroleum Geologists Bulletin, v. 60 , no. 9 , p. $1502-1519$.

Mirchink, M.F., Khachatryan, R.O., Gromeka, V.I., Mitreykin, Yu.B., Mkrtchyan, O.M., and Nartov, G.V., 1965, Tektonika i zony neftegazonakopleniya Kamsko-Kinelskoy sistemy progibov [Tectonics and petroleum zones of the Kama-Kinel system of depressions]: Moscow, Nauka, 213 p.

Mirzoyev, D.A., and Dzhaparidze, L.I., 1979, K opredeleniyu katageneza rasseyannogo organicheskogo veshestva $i$ usloviy proyavleniya faz neftegazoobrazovaniya $v$ osadochnykh kompleksakh platformennogo chekhla Vostochnogo Predkavkaz'ya [Evaluation of catagenesis of disseminated organic materials and the conditions indicating oil and gas maturation stages in sedimentary rocks of the platform cover in eastern Ciscaucasia], in Vassoyevich, N.B., and Timofeyev, P.P., eds., Neftematerinskiye svity i printsipy ikh diagnostiki: Moscow, Nauka, p. 200-208.

Molenaar, C.M., Bird, K.J., and Kirk, A.R., 1987, Cretaceous and Tertiary stratigraphy of northeastern Alaska, in Tailleur, Irv, and Weimer, Paul, eds., Alaskan North Slope geology: Bakersfield, Calif., Society of Economic Paleontologists and Mineralogists, Pacific Section, v. 1, p. 513-528.

Moshier, S.O., and Waples, D.W., 1985, Quantitative evaluation of Lower Cretaceous Manville Group as source rocks for Alberta's oil sands: American Association of Petroleum Geologists Bulletin, v. 69, no. 2, p. 161-172.

Mosmann, Raul, Falkenhein, F.U.H., Gonçalves, Alfredo, and Filho, F.N., 1986, Oil and gas potential of the Amazon Paleozoic basins, in Halbouty, M.T., ed., Future petroleum provinces of the world: American Association of Petroleum Geologists Memoir 40, p. 207-241.

Murris, R.J., 1980, Hydrocarbon habitat of the Middle East, in Miall, A.D., ed., Facts and principles of world petroleum occurrence: Canadian Society of Petroleum Geologists Memoir 6, p. 765-800.

Nehring, Richard, 1978, Giant oil fields and world oil resources: Santa Monica, Calif., Rand Corporation, Report R-2284-CIA, 162 p.

Nesterov, I.I., Nemchenko, N.N., and Rovenskaya, A.S., 1978, Argon isotopes and genesis of natural gas of northwestern Siberia: Akademiya Nauk SSSR, Doklady, v. 230 , p. 239-240.

Nikiforova, O.I., and Obut, A.M., 1965, Siluriyskaya sistema [Silurian System]: Moscow, Akademiya Nauk SSSR, Stratigrafiya SSSR series, $531 \mathrm{p}$.

Nikonov, M.N., 1959, O predposylkakh ugleobrazovaniya v svete dannykh o sovremennykh torfyanykh zalezhakh [Prerequisites for formation of coal in light of data on the present-day peat deposits], in Karavaev, N.M., and Titov, N.G., eds., Genezis tverdykh goryuchikh iskopaemykh: Moscow, Akademiya Nauk SSSR, p. 51-56.
North, F.K., 1979 and 1980, Episodes of source-sediment deposition: Journal of Petroleum Geology, v. 2, no. 2, p. 199-218, and no. 3, p. 323-338.

1985, Petroleum geology: London and Sidney, Allen and Unwin, Inc., 607 p.

Nwachukwu, J.I., and Chukwura, P.I., 1986, Organic matter of Agbada Formation, Niger Delta, Nigeria: American Association of Petroleum Geologists Bulletin, v. 70, no. 1, p. 48-55.

Oehler, J.H., 1984, Carbonate source rocks in the Jurassic Smackover trend of Mississippi, Alabama, and Florida, in Palacas, J.G., ed., Petroleum geochemistry and source rock potential of carbonate rocks: American Association of Petroleum Geologists Studies in Geology, no. 18, p. 63-69.

Paraschiv, D., and Olteanu, Gh., 1970, Oil fields in MiocenePliocene zone of eastern Carpathians (District of Ploiești), in Halbouty, M.T., ed., Geology of giant petroleum fields: American Association of Petroleum Geologists Memoir 14, p. 399-427.

Parparova, G.M., Neruchev, S.G., Ginzburg, A.I., Zhukova, A.V., and Rudavskaya, V.A., 1986, $\mathrm{K}$ voprosu ob evolyutsii iskhodnogo materiala $\mathrm{i}$ petrograficheskikh tipov sapropelevogo organicheskogo veshchestva raznovozrastnykh domanikoidov [Evolution of the original material and petrographic types of the sapropelic organic matter of Domanik-type rocks of different ages], in Eremenko, N.A., Neruchev, S.G., Sokolov, B.A., and Bazhenova, O.K., eds., Evolyutsiya neftegazoobrazovaniya v istorii Zemli: Moscow, Nauka, p. 21-26.

Parrish, J.T., 1982, Upwelling and petroleum source beds, with reference to the Paleozoic: American Association of Petroleum Geologists Bulletin, v. 66, no. 6, p. 750-774.

Parsons, W.H., 1973, Alberta, in McCrossan, R.G., ed., The future petroleum provinces of Canada-Their geology and potential: Canadian Society of Petroleum Geologists Memoir 1, p. 73-120.

Pel'man, Yu.L., 1982, Ekologicheskiye gruppirovki fauny v srednekembriyskikh domanikoidnykh otlozheniyakh Kuonamskoy svity (Sibirskaya platforma, r. Muna) [Ecologic grouping of fauna in Domanik-type rocks of the Middle Cambrian Kuonam Formation, Siberian Platform, Muna River], in Betekhtina, O.A., and Zhuravleva, I.T., eds., Sreda i zhizn' v geologicheskom proshlom-Paleolandshafty i biofatsii: Trudy Instituta Geologii i Geofiziki (Novosibirsk), no. 510, p. 60-74.

Peterson, J.A., 1983, Petroleum geology and resources of southeastern Mexico, northern Guatemala, and Belize: U.S. Geological Survey Circular 760, 44 p. 1985, Petroleum geology and resources of northeastern Mexico: U.S. Geological Survey Circular 943, 30 p.

Peterson, J.A., and Smith, D.L., 1986, Rocky Mountain paleogeography through geologic time, in Peterson, J.A., ed., Paleotectonics and sedimentation in the Rocky Mountain region: American Association of Petroleum Geologists Memoir 41, p. 3-20.

Petroconsultants, 1982, Overview of source rocks for oil and gas, a worldwide survey: Geneva, Petroconsultants Ltd. [pagination varies]. 
Podruski, J.A., Barclay, J.E., Hamblin, A.P., Lee, P.J., Osadetz, K.G., Procter, R.M., and Taylor, G.C., 1988, Conventional oil resources of western Canada (light and medium): Geological Survey of Canada Paper 87-26, $149 \mathrm{p}$.

Ponte, F.C., Fonseca, J.D.R., and Carozzi, A.V., 1980, Petroleum habitat in the Mesozoic-Cenozoic of the continental margin of Brazil, in Miall, A.D., ed., Facts and principles of world petroleum occurrence: Canadian Society of Petroleum Geologists Memoir 6, p. 857-886.

Porter, J.W., Price, R.A., and McCrossan, R.G., 1982, The Western Canada sedimentary basin: Philosophical Transactions of the Royal Society of London, ser. A, v. 305, p. 169-192.

Procter, R.M., Taylor, G.C., and Wade, J.A., 1984, Oil and natural gas resources of Canada: Geological Survey of Canada Paper 83-31, 59 p.

Raaben, V.F., 1986, Osnovnyye tipy neftegazonosnykh terretoriy mira [Main types of petroleum productive regions of the world]: Moscow, Nedra, $160 \mathrm{p}$.

Rainwater, E.H., 1971, Possible future petroleum potential of Lower Cretaceous, western Gulf basin, in Cram, I.H., ed., Future petroleum provinces of the United States-Their geology and potential: American Association of Petroleum Geologists Memoir 15, v. 2, p. 901-926.

Raudsepp, Kh.T., 1959, Proiskhozhdeniye kukersitovykh goryuchikh slantsev Estonii [Genesis of kukersite oil shale of Estonia], in Karavaev, N.M., and Titov, N.G., eds., Genezis tverdykh goryuchikh iskopaemykh: Moscow, Akademiya Nauk SSSR, p. 69-76.

Ray, E.O., 1971, Petroleum potential of eastern Kentucky, in Cram, I.H., ed., Future petroleum provinces of the United States-Their geology and potential: American Association of Petroleum Geologists Memoir 15, v. 2, p. 1261-1268.

Reynolds, M.W., Palacas, J.G., and Elston, D.P., 1988, Potential petroleum source rocks in the late Proterozoic Chuar Group, Grand Canyon, Arizona, in Carter, L.M.H., ed., U.S. Geological Survey research on energy resources-1988, program and abstracts: U.S. Geological Survey Circular 1025, p. 49-50.

Rhoads, D.C., and Morse, J.W., 1971, Evolutionary and ecologic significance of oxygen-deficient marine basins: Lethaia, v. 4, p. 413-428.

Rice, D.D., and Claypool, G.E., 1981, Generation, accumulation, and resource potential of biogenic gas: American Association of Petroleum Geologists Bulletin, v. 65 , no. 1 , p. $5-25$.

Richards, P.W., 1952, The tropical rain forest-An ecological study: Cambridge, England, Cambridge University Press, $450 \mathrm{p}$.

Riva, J.P., Jr., 1988, Oil distribution and production potential: Oil and Gas Journal, v. 86, no. 3, (Jan. 18), p. 58-61.

Roadifer, R.E., 1986, Giant fields-1, Size distributions of world's largest known oil, tar accumulations: Oil and Gas Journal, v. 84, no. 8 (Feb. 24), p. 93-100.

Robinson, K.M., 1987, An overview of source rocks and oils in Indonesia: Indonesian Petroleum Association Proceedings, 16th Annual Convention, October 1987, IPA $87-11 / 06$, p. 97-122.
Robison, R.A., 1987, Phylum Annelida, in Boardman, R.S., Cheetham, A.H., and Rowell, A.J., eds., Fossil invertebrates: Palo Alto, Calif., Blackwell Scientific Publications, p. 194-204.

Rudkevich, M.Ya., Ozeranskaya, L.S., Chistyakova, N.F., Kornev, V.A., and Maksimov, Ye.N., 1988, Neftegazonosnye kompleksy Zapodno-Sibirskogo basseyna [Petroleum productive formations of the West Siberian basin]: Moscow, Nedra, 304 p.

Russell, D.J., 1985, Depositional analysis of a black shale by using gamma-ray stratigraphy-The Upper Devonian Kettle Point Formation of Ontario: Bulletin of Canadian Petroleum Geology, v. 33, no. 2, p. 236-253.

Safranov, T.A., Gotgil'f, A.V., and Deymontovich, Ye.B., 1983, Prognoz neftegazonosnosti osadochnykh tolshch AfganoTadzhikskoy vpadiny po geokhimicheskim kriteriyam [Petroleum potential of sedimentary rocks of the AfghanTadzhik basin based on geochemical criteria]: Geologiya Nefti i Gaza, 1983, no. 8, p. 28-34.

Salvador, Amos, 1987, Late Triassic-Jurassic paleogeograpı, and origin of Gulf of Mexico basin: American Association of Petroleum Geologists Bulletin, v. 71, no. 4, p. 419-451.

Salvador, Amos, and Green, A.R., 1980, Opening of the Caribbean Tethys, in Aubouin, Jean, Debelmas, Jacques, and Latreille, Michel, eds., Geology des chaines alpines issues de la Tethysm; Geology of the Alpine chains born of the Tethys: International Geological Congress, 26th, Paris, July 7-17, 1980, colloquium C5; [France] Bureau de Recherches Géologiques et Minières, Mémoires, no. 115 , p. 224-229.

Sandberg, C.A., and Gutschick, R.C., 1979, Guide to conodont biostratigraphy of Upper Devonian and Mississippian rocks along the Wasatch Front and Cordilleran hingeline, Utah, in Sandberg, C.A., and Clark, D.L., eds., Conodont biostratigraphy of the Great Basin and Rocky Mountains: Brigham Young University Geology Studies, v. 26, pt. 3, p. 107-134.

1984, Distribution, microfauna, and source-rock potential of Mississippian Delle Phosphatic Member of Woodman Formation and equivalents, Utah and adjacent States, in Woodward, Jane, Meissner, F.F., and Clayton, J.L., eds., Hydrocarbon source rocks of the greater Rocky Mountains region: Denver, Colo., Rocky Mountain Association of Geologists, p. 135-178.

Schopf, J.W., and Walter, M.R., 1983, Archean microfossils-New evidence of ancient microbes, in Schopf, J.W., ed., Earth's earliest biosphere, its origin and evolution: Princeton, N.J., Princeton University Press, p. 214-239.

Scotese, C.R., Bambach, R.K., Barton, Colleen, Van der Voo, Rob, and Ziegler, A.M., 1979, Paleozoic base maps: Journal of Geology, v. 87, no. 3, p. 217-277.

Seilacher, Adolf, 1977, Evolution of trace fossil communities, chapter 11 of Hallam, A., ed., Patterns of evolution, as illustrated by the fossil record: Amsterdam, Oxford, New York, Elsevier Scientific Publishing Company, Developments in paleontology and stratigraphy, 5, p. 359-376. 
Semashev, R.G., 1983, O gidrogeologicheskikh usloviyakh gazonakopleniya $\mathbf{v}$ Murgabskoy vpadine [Hydrogeologic conditions of gas accumulation in the Murghab basin]: Geologiya Nefti i Gaza, 1983, no. 10, p. 43-49.

Seregin, A.M., Moskalev, N.P., and Naser, M., 1982, Usloviya generatsii $i$ akkumulyatsii nefti $i$ gaza $v$ mezozoyskikh otlozheniyakh yugo-vostochnoy chasti Karakumskogo osadochnogo neftegazonosnogo basseyna [Conditions of hydrocarbon generation and accumulation in Mesozoic rocks of the southeastern Karakum sedimentary petroleum basin], in Vassoevich, N.B., Polster, L.A., and Bazhenova, O.K., eds., Metody otsenki nefte- i gazomaterinskogo potentsiala sedimentitov: Moscow, Nauka, p. $180-188$.

Shanmugam, G., 1985, Significance of coniferous rain forests and related organic matter in generating commercial quantities of oil, Gippsland basin, Australia: American Association of Petroleum Geologists Bulletin, v. 69, no. 8, p. 1241-1254.

herbakov, V.V., Kravchuk, M.S., and Yefimov, V.I., 1983, Stroyeniye maykopskogo osadochnogo basseyna Azovskogo morya [Structure of the Maykop sedimentary basin of the Sea of Azov]: Geologiya Nefti i Gaza, 1983, no. 5 , p. $38-44$.

Shestopal, B.A., 1979, Neftegazomaterinskiy potentsial porod mela i paleogena Ravninnogo Kryma [Oil- and gasgenerative potential of Cretaceous and Paleogene rocks of the Crimean Plain], in Vassoyevich, N.B., and Timofeyev, P.P., eds., Neftematerinskiye svity i printsipy ikh diagnostiki: Moscow, Nauka, p. 166-175.

Smith, A.G., Hurley, A.M., and Briden, J.C., eds., 1981, Phanerozoic paleocontinental world maps: London, Cambridge University Press, 102 p.

Snowdon, L.R., 1980, Resinite-A potential petroleum source in the Upper Cretaceous-Tertiary of the BeaufortMackenzie basin, in Miall, A.D., ed., Facts and principles of world petroleum occurrence: Canadian Society of Petroleum Geologists Memoir 6, p. 509-521.

Snowdon, L.R., and Powell, T.G., 1982, Immature oil and condensate-Modification of hydrocarbon generation model for terrestrial organic matter: American Association of Petroleum Geologists Bulletin, v. 66, no. 6, p. 775-788.

Sokolov, B.A., 1980, Evolyutsiya i neftegazonosnost' osadochnykh basseynov [Evolution and petroleum productivity of sedimentary basins]: Moscow, Nauka, 243 p.

Sokolov, B.S., 1979, Paleontologiya dokembriya [Paleontology of the Precambrian], in Sokolov, B.S., ed., Paleontologiya dokembriya i rannego kembriya: Leningrad, Nauka, p. 5-16.

Sokolowski, Stanislaw, Cieślińki, Stefan, and Czermiński, Jan, eds., 1970, Geology of Poland, v. 1, Stratigraphy, pt. 1, Pre-Cambrian and Palaeozoic: Warsaw, Instytut Geologiczny, $635 \mathrm{p}$.

Stasova, O.F., 1977, Tipy mezozoyskikh nefty Zapadnoy Sibiri [Types of Mesozoic oils of West Siberia], in Konţorovich, A.E., and Uspensky, V.A., eds., Rasseyannoye organicheskoye veshchestvo gornykh porod i metody yego izucheniya: Trudy Instituta Geologii i Geofiziki (Novosibirsk), no. 334, p. 83-88.
Stauffer, J.E., 1971, Petroleum potential of Big Horn Basin and Wind River Basin-Casper arch area, Wyoming, and Crazy Mountain basin-Bull Mountains basin area, Montana, in Cram, I.H., ed., Future petroleum provinces of the United States-Their geology and potential: American Association of Petroleum Geologists Memoir 15 , v. 1, p. 613-655.

Stewart, W.N., 1983, Paleobotany and the evolution of plants: New York, Cambridge University Press, 405 p.

Stoakes, F.A., 1980, Nature and control of shale basin fill and its effect on reef growth and termination-Upper Devonian Duvernay and Ireton Formations of Alberta, Canada: Bulletin of Canadian Petroleum Geology, v. 28, no. 3, p. 345-410.

Surlyk, Finn, 1980, Denmark, in Geology of the European countries: [Paris] BORDAS and 26th International Geological Congress, v. 2, p. 1-50.

Tang Zeyao and Zhang Shengyu, 1984, Forming conditions of Sinian gas pools in Sichuan basin: Beijing Petroleum Geology Symposium, September 1984, Beijing, China, Preprint, 21 p.

Tanzil, Stephen, 1985, Distribution of world oil resources: Oil and Gas Journal, v. 83, no. 22 (June 3), p. 86-90.

Tappan, Helen, 1980, The paleobiology of plant protists: San Francisco, W.H. Freeman and Company, 1028 p.

Tasch, Paul, 1973, Paleobiology of the invertebrates: New York, John Wiley and Sons, 975 p.

Tesakov, Yu.I., Predtechenskiy, N.N., Khromykh, V.G., and Berger, A.Ya., 1986, Siluriyskiye biogeotsenozy severa Sibirskoy platformy (basseyn r. Moyyero) [Silurian biogeocenoses of the northern Siberian craton-The Moyyero River basin], in Sokolov, B.S., ed., Fauna i flora silura Zapolyar'ya Sibirskoy platformy: Trudy Instituta Geologii i Geofiziki (Novosibirsk), no. 666, p. 5-84.

Tipsword, H.L., Fowler, W.A., Jr., and Sorrell, B.J., 1971, Possible future petroleum potential of lower MioceneOligocene, western Gulf basin, in Cram, I.H., ed., Future petroleum provinces of the United States-Their geology and potential: American Association of Petroleum Geologists Memoir 15, v. 2, p. 836-854.

Tissot, B., Demaison, G., Masson, P., Delteil, J.R,. and Combaz, A., 1984, Paleoenvironment and petroleum potential of middle Cretaceous black shales in Atlantic basins, in Demaison, Gerard, and Murris, R.J., eds., Petroleum geochemistry and basin evaluation: American Association of Petroleum Geologists Memoir 35, p. 217-227.

Tissot, B., Espitalie, J., Deroo, G., Tempere, C., and Jonathan, D., 1984, Origin and migration of hydrocarbons in the eastern Sahara (Algeria), in Demaison, Gerard, and Murris, R.J., eds., Petroleum geochemistry and basin evaluation: American Association of Petroleum Geologists Memoir 35, p. 315-324.

Tissot, B.P., and Welte, D.H., 1984, Petroleum formation and occurrence (2d ed.): Berlin, Heidelberg, New York, Tokyo, Springer-Verlag, 699 p. 
Tomczykowa, Ewa, and Tomczyk, Henryk, 1971, Samyye verkhi ludlova v Pol'she [The uppermost Ludlovian in Poland]: Mezhdunardnyy simpozium po granitse silura i devona $i$ biostratigrafiya silura, nizhego i srednego devona, Leningrad, Trudy, no. 3, v. 1, p. 207-210.

Tong Chongguan, 1980, Some characteristics of petroleum geology of the rift system in eastern China: Acta Petrolei Sinica, v. 1 , no. 4 , p. 19-26

Trettin, H.P., 1978, Middle Ordovician to Lower Devonian deep-water succession at southeastern margin of Hazen trough, Canon Fiord, Ellesmere Island: Geological Survey of Canada Bulletin 272, 69 p.

Trotsyuk, V.Ya., and Marina, M.M., 1988, Organicheskiy uglerod v otlozheniyakh Mirovogo okeana [Organic carbon in sediments of the world's oceans]: Moscow, Nauka, $175 \mathrm{p}$.

Turner, B.R., 1980, Paleozoic sedimentology of the southeastern part of $\mathrm{Al}$ Kufrah basin, Libya-A model for oil exploration, in Salem, M.J., and Busrewil, M.T., eds., The geology of Libya: London, Academic Press, v. 2, p. 351-374.

Ulmishek, Gregory, 1982, Petroleum geology and resource assessment of the Timan-Pechora basin, U.S.S.R., and the adjacent Barents-northern Kara shelf: Argonne National Laboratory Report ANL/EES-TM-199, 197 p. 1986, Stratigraphic aspects of petroleum resource assessment, in Rice, D.D., ed., Oil and gas assessment, methods and applications: American Association of Petroleum Geologists Studies in Geology, no. 21, p. 59-68.

1988, Upper Devonian-Tournaisian facies and oil resources of the Russian craton's eastern margin, in McMillan, N.J., Embry, A.F., and Class, D.J., eds., Devonian of the world, volume 1-Regional synthesis: Calgary, Alberta, Canadian Society of Petroleum Geologists, p. 527-549.

U.S. Department of Energy and U.S. Geological Survey, 1979, Report on the petroleum resources of the Federal Republic of Nigeria: Report DOE/IA-008, 63 p. Available from National Technical Information Service, Springfield, VA 22161.

U.S. Energy Information Administration, 1983a, The petroleum resources of the Middle East: Report DOE/EIA-0395, 180 p. Available from Superintendent of Documents, U.S. Government Printing Office, Washington, DC 20402.

1983b, The petroleum resources of the North Sea: Report DOE/EIA-0381, 97 p. Available from Superintendent of Documents, U.S. Government Printing Office, Washington, DC 20402.

1983c, The petroleum resources of Mexico: Report DOE/EIA-0423, 107 p. Available from Superintendent of Documents, U.S. Government Printing Office, Washington, DC 20402.

Van der Voo, Rob, 1988, Paleozoic paleogeography of North America, Gondwana, and intervening displaced terranes-Comparisons of paleomagnetism with paleoclimatology and biogeographical patterns: Geological Society of America Bulletin, v. 100, no. 3, p. 311-324.
Vasserman, B.Ya., Bogatskiy, V.I., and Shafran, Ye.B., 1977, Ordoviksko-nizhnedevonskiye otlozheniya-novyy ob'ekt razvedki no neft' i gaz na severo-vostoke Yevropeyskoy chasti SSSR [Ordovician-Lower Devonian sequenceNew target for exploration for oil and gas on the northeast of the European part of the U.S.S.R.]: Geologiya Nefti i Gaza, 1977, no. 10, p. 34-40.

Vitenko, V.A., Novosiletsky, R.M., and Shevchenko, E.F., 1985, Neftegazogeneratsionnyy potentsial otlozheniy osnovnykh neftegazonosnykh regionov Ukrainy [Oil and gas source potential of rocks in the main hydrocarbon productive regions of the Ukraine], in Timofeyev, P.P., ed., Organicheskoye veshchestvo sovremennykh $\mathrm{i}$ iskopayemykh osadkov: Moscow, Nauka, p. 147-151.

Vyshemirskiy, V.S., ed., 1986, Bazhenovskiy gorizont Zapadnoy Sibiri (stratigrafiya, paleogeografiya, ekosistemy, neftenosnost') [The Bazhenov horizon of West Siberia-Stratigraphy, paleogeography, ecosystems, oilproducing capacity]: Trudy Instituta Geologii i Geofizir(Novosibirsk), no. 649, 217 p.

Wang Shangwen, Zhang Wanxuan, Zhang Houfu, and Tan Shidian, 1983, Sichuan basin, in Petroleum geology of China: Beijing, China, Petroleum Industry Press, p. 285-293.

Webster, R.L., 1984, Petroleum source rocks and stratigraphy of the Bakken Formation in North Dakota, in Woodward, Jane, Meissner, F.F., and Clayton, J.L., eds., Hydrocarbon source rocks of the greater Rocky Mountain region: Denver, Colo., Rocky Mountain Association of Geologists, p. 57-81.

Yang Wanli, 1985, Daqing oil field, People's Republic of China-A giant field with oil of nonmarine origin: American Association of Petroleum Geologists Bulletin, v. 69 , no. 7, p. 1101-1111.

Yang Wanli, Li Yongkang, and Gao Ruiqi, 1985, Formation and evolution of nonmarine petroleum in Songliao basin, China: American Association of Petroleum Geologists Bulletin, v. 69, no. 7, p. 1112-1122.

Young, Allen, Monaghan, P.H., and Schweisberger, R.T., 1977, Calculation of ages of hydrocarbons in oils-Physical chemistry applied to petroleum geochemistry I: American Association of Petroleum Geologists Bulletin, v. 61 , no. 4 , p. 573-600.

Zambrano, E., Vasquez, E., Duval, B., Latrielle, M., and Coffinieres, B., 1972, Paleogeographic and petroleum synthesis of western Venezuela: Paris, Editions Technip, $62 \mathrm{p}$.

Zha Quanheng, 1984, Jizhong depression, China-its geologic framework, evolutionary history, and distribution of hydrocarbons: American Association of Petroleum Geologists Bulletin, v. 68, no. 8, p. 983-992.

Zhang Jiazhen, 1985, Huabei-Bohaiwan basin, in ESCAP atlas of stratigraphy IV-People's Republic of China, volume 10 of Stratigraphic correlation between sedimentary basins of the ESCAP region: United Nations, Mineral Resources Development Series, no. 52, p. 22-27.

Zhizhchenko, B.P., 1969, Metody stratigraficheskikh issledovaniy neftegazonosnykh oblastey [Methodologies of stratigraphic studies in petroleum regions]: Moscow, Nedra, 373 p. 
Zhou Zhennan, Qiu Songyu, and Huang Changnian, 1985, Songliao basin, in ESCAP atlas of stratigraphy IVPeople's Republic of China, volume 10 of Stratigraphic correlation between sedimentary basins of the ESCAP region: United Nations, Mineral Resources Development Series, no. 52, p. 13-21.

Zhuravleva, I.T., 1985, Metod karkasnogo paleoekologofatsial'nogo analiza i izucheniye organogennykh postroyek [A method for skeletal paleoecologic-facies analysis and the study of biogenic structures], in Betekhtina, O.A., and Zhuravleva, I.T., eds., Sreda i zhizn' v geologicheskom proshlom-Paleobasseyny i ikh obitateli: Trudy Instituta Geologii i Geofiziki (Novosibirsk), no. 628 , p. $107-119$.

Zhuze, N.G., Neyman, G.V., and Dukal'skaya, I.M., 1975, Sravnitel'naya kharakteristika nefteproizvodyashchikh svit karbonatnykh formatsiy [Comparative characteristics of oil-producing suites of carbonate formations]: Sovetskaya Geologiya, no. 4, p. 9-22.

Ziegler, A.M., Scotese, C.R., and Barrett, S.F., 1982, Mesozoic and Cenozoic paleogeographic maps, in Brosche, $\mathrm{P}$., and Sündermann, J., eds., Tidal friction and the Earth's rotation II: Berlin, Springer-Verlag, p. 240-252.

Ziegler, P.A., 1980, Northwest European basin-Geology and hydrocarbon provinces, in Miall, A.D., ed., Facts and principles of world petroleum occurrence: Canadian Society of Petroleum Geologists Memoir 6, p. 653-706.

Zumberge, J.E., 1984, Source rocks of the La Luna Formation (Upper Cretaceous) in the Middle Magdalena Valley, Colombia, in Palacas, J.G., ed., Petroleum geochemistry and source rock potential of carbonate rocks: American Association of Petroleum Geologists Studies in Geology, no. 18 , p. $127-133$. 
-

1 